\title{
Productive Capacities, Economic Growth and Economic Growth Volatility in Developing Countries: Does Structural Economic Vulnerability Matter?
}

\author{
Author: Sèna Kimm GNANGNON ${ }^{1}$
}

Manuscript date: April 2021

\begin{abstract}
Recent years' global shocks (e.g., the 2008 financial crisis and the COVID-19 pandemic) and environmental shocks - such as natural disasters - have heightened the vulnerability of developing countries to future shocks, and can compromise their development prospects. International institutions and researchers have advocated that the strengthening of productive capacities in these countries would help them enhance the resilience of their economies to shocks, and promote sustainable development. The present paper has examined the effect of productive capacities on economic growth and economic growth volatility in developing countries, in particular when they face a high level of structural economic vulnerability. The analysis covers 117 developing countries over the period 2000-2018. It shows that productive capacities do not only promote economic growth, but also reduce economic growth volatility. On the other hand, structural economic vulnerability reduces economic growth, in particular when it exceeds a certain level, and induces greater volatility of economic growth. Interestingly, the findings suggest that productive capacities promote economic growth and reduce economic growth volatility in countries that face a high degree of structural economic vulnerability. These findings support the recommendation by international institutions and researchers that if they were to enhance the resilience of their economies to shocks, and promote sustainable economic growth, developing countries (in particular the poorest ones) should strengthen their productive capacities.
\end{abstract}

Keywords: Productive capacities; Economic growth; Economic growth volatility; Structural Economic Vulnerability.

JEL Classification: D24; O10; O40; O47; E32.

${ }^{1}$ World Trade Organization (WTO). E-mail for correspondence: kgnangnon@yahoo.fr 
Affiliation: World Trade Organization

Postal Address: Rue de Lausanne 154, CH-1211 Geneva 21, Switzerland. E-mail: kgnangnon $a_{\text {yahoo.fr }}$

\section{DISCLAIMER}

This is a working paper, which represents the personal opinions of individual staff members and is not meant to represent the position or opinions of the WTO or its Members, nor the official position of any staff members. Any errors or omissions are the fault of the author. The author declares no competing interests. 


\section{Introduction}

The literature has now well established that the proneness of developing countries to shocks ${ }^{2}$, and the subsequent size and frequency of these shocks (e.g., Aguiar and Gopinath, 2007; Cariolle et al. 2016; Guillaumont, 2009; Goujon and Guillaumont, 2016; Essers, 2013) reduce their economic growth (e.g., Almansour et al., 2015; Azomahou et al., 2015; Bacha, 1986; Blecker, 2009; Dabla-Norris and Gündüz, 2014; Guillaumont and Wagner, 2012) and contribute to strong fluctuations of economic growth (e.g., Barrot et al. 2018; Kim et al., 2020; Letendre and Obaid, 2020; Kose and Riezman, 2001; Kpodar et al., 2018; Raddatz, 2007; 2008; Rasaki and Malikane, 2015).

Some recent papers have developed the concept of 'structural economic vulnerability' as a way to capture the degree of developing countries' exposure to shocks and extent of shocks, and examine its effect on economic growth (e.g., Guillaumont and Wagner, 2012; Cordina, 2004; Wagner, 2014). Structural economic vulnerability is defined as the "risk of a (poor) country seeing its development hampered by the natural or external shocks it faces." This concept is particularly useful for national and international policymaking: the United Nations (UN) has developed the index of structural economic vulnerability, which is used as one of the criteria to identify which countries in the world can be considered as a Least-developed country $\left(\mathrm{LDCs}^{3}\right)$. The group of LDCs is comprised of countries in the world that are the poorest and most vulnerable to environmental and external shocks. This means that these countries are not only poor, but they also exhibit high levels of structural economic vulnerability compared to other developing countries.

International institutions (such as the United Nations and the World Trade Organization) and researchers ${ }^{4}$ have also stressed the importance of strengthening productive capacities in developing countries, and notably in $\mathrm{LDCs}^{5}$ so as to enhance the resilience of their economies to shocks, and engage them on a sustainable development path. To help researchers and policymakers diagnose productive capacity performance, and assess the appropriate policies needed to strengthen it, the UNCTAD has launched ${ }^{6}$ in February 2021 a new index of productive capacities, the latter being defined as "the productive resources, entrepreneurial capabilities and production linkages which together determine the capacity of a country to produce goods and services and enable it to grow and develop" (see UNCTAD, 2006; 2020a; 2020b).

While international institutions and researchers have usually argued that developing productive capacities would contribute to improving economic growth performance, and enhancing resilience to shocks in developing countries, the effects of productive capacities (in

${ }^{2}$ Such shocks can include terms of trade shocks (for example, shocks to commodity prices); shocks to export demand; volatility of financial flows; natural disasters, as well as health shocks, exemplified by the COVID-19 pandemic (Essers, 2013; Guillaumont, 2009; 2010; Goujon and Guillaumont, 2016).

3 The category of LDCs was established for the first time by the United Nations General Assembly in 1971. More information on the group of LDCs, including the set of criteria used to include a country in this group or graduate it from the group, is provided by the United Nations online at: https://www.un.org/ohrlls/content/leastdeveloped-countries

4 They include for example Andreoni (2012); Cornia and Scognamillo (2016); Freire (2011); Gnangnon (2018, 2019); Hynes and Lammersen (2017); OECD/WTO (2019); OECD (2007); Shiferaw (2017); UN (2017); UNCTAD (2020a, 2020b) and UNIDO (2001).

${ }^{5}$ LDCs are particularly featured, compared to other developing countries, by very low levels of productive capacities, and concurrently their high level of structural economic vulnerability.

6 See information online at: https://unctad.org/press-material/unctad-launches-new-tool-help-transformeconomies-amid-global-crisis and https://unctadstat.unctad.org/EN/Pci.html 
particular, as defined above) on economic growth and economic growth volatility have received little attention in the empirical literature. This has probably been due to the lack of cross-country comparable data on productive capacities. On the one hand, there is no evidence-based work on the effect of productive capacities on economic growth volatility, and on the other hand, the few existing works on the relationship between productive capacities and economic growth (e.g., Shiferaw, 2017; UNCTAD, 2020b) have essentially rely on descriptive statistics. By making available a dataset on the measure of productive capacities for the majority of countries in the world, the UNCTAD allows now the research community to undertake analysis on the determinants as well as effects of productive capacities.

The current paper is, to the best of our knowledge, one of the first that uses the new UNCTAD's index of productive capacities to investigate the effect of productive capacities on economic growth and economic growth volatility in developing countries, in particular when the latter face high levels of structural vulnerability.

The dataset used in the analysis contains 117 countries over the period 2000-2018. Results, based on the two-step system Generalized Methods of Moments (GMM) technique, have shown that while productive capacities contribute to improving economic growth and reducing economic growth volatility, structural economic vulnerability reduces economic growth (in particular when it exceeds a certain level), and exerts a positive effect on economic growth volatility. More importantly, empirical findings spotlight the essential role of productive capacities in alleviating the adverse effects of structural economic vulnerability on economic growth and economic growth volatility. Specifically, it appears that productive capacities enhance economic growth and reduce economic growth volatility in countries that experience a high degree of structural economic vulnerability.

These findings lend support to the recommendation by researchers and international institutions (such as the United Nations and the WTO) that helping developing, including LDCs to develop productive capacities would help to promote economic growth in these countries, and protect them from the economic growth fluctuations induced by their vulnerability to external and environmental shocks.

The rest of the paper contains seven sections. Sections 2 and 3 provide a theoretical discussion on how productive capacities and structural economic vulnerability can affect economic growth and economic growth volatility. Section 4 presents the model specifications that help to address the issues at the heart of the analysis. Section 5 presents an analysis of data concerning the key variables of interest. Section 6 discusses the empirical strategy, and Section 7 interprets empirical outcomes. Section 8 concludes.

\section{Discussion on the effect of productive capacities and structural economic vulnerability on economic growth}

\subsection{Effect of productive capacities on economic growth}

According to the UNCTAD (UNCTAD, 2006; 2020), the concept of "productive capacities" has three main dimensions, including productive resources, entrepreneurial capabilities and production linkages which together, determine a country's capacity to produce goods and services and enable it to grow and develop. In light of this definition, the UNCTAD has identified 
eight broad categories defined over many indicators that reflect these main channels through which a country could develop its productive capacities (UNCTAD, 2020). These categories include energy; transport infrastructure; information and communication technology (ICTs); natural resources; human capital; institutions; private sector; and structural change in production. Therefore, discussing the effects of productive capacities on economic growth involves discussing how each main dimension of this concept affects economic growth.

\subsubsection{Effect of physical capital on economic growth}

The effect of productive resources - that include physical capital (e.g., hard and soft infrastructure) and resources accumulation (including human capital accumulated, and natural resources) on economic growth has been largely discussed in the literature. This effect takes place through, inter alia, higher labour productivity, including productivity gains in the private sector. According to Lewis (1954), capital accumulation (both physical and human) are critical for enhancing labour productivity, by helping to move from agriculture-based economies (that have low productivity) to modern economies with high labour productivity.

However, there is no consensus in the voluminous empirical literature ${ }^{7}$ on the direction of the effect of infrastructure on economic growth. Many studies have pointed out the positive effect of the development physical infrastructure on economic growth, notably in developing countries (e.g., Calderón et al., 2015; Chakamera and Alagidede, 2018; Démurger, 2001; Fan and Zhang, 2004; Pradhan and Bagchi, 2013; Sahoo and Dash, 2012), the findings by other studies are more nuanced. For example, according to the World Bank (1994), infrastructure investment contributes to promoting economic growth only if it is accompanied by favourable overall economic policy conditions, as otherwise, the returns from infrastructure investment decline. Shi et al. (2017) have looked at the effect of four types of infrastructure (electricity generating capacity, roadway, railway, and telecommunications) on economic growth in China. They have uncovered a mixed evidence across time period and regions concerning the contribution of infrastructure investment to economic development. Specifically, road construction in lagging regions has exerted a negative effect on economic development. According to the authors, these findings reflect the existence of an inverse U-shaped relationship between infrastructure investment and growth, whereby a dominance of infrastructure investment may crowd-out private capital. Ke et al. (2020) have examined the impacts of the quantity, quality, and structural aspects of transport infrastructure on regional economic growth in China. They have observed that while quality improvements in roads and railways, as well as the structural upgrading of transport infrastructure contribute significantly to economic growth, a quantity expansion of the overall land transport network has exerted no significant effect on economic growth. Wang et al. (2020) have provided strong empirical support that China's Belt and Road Initiative (BRI), through development of transport infrastructure (railway and road), holds a great potential for promoting regional economic growth in Asia, Europe and Africa, as well as national economic growth in BRI countries in Asia, Europe and Africa.

On another note, the development of ICT tools could promote economic growth through a variety of channels such as productivity efficiency, employment creation, reduction of transaction costs, better education and skills, social and political stability as well as economic freedom (e.g.,

7 Timilsina et al. (2020) have provided a literature review on the effect of infrastructure development on economic growth. 
Pradhan et al., 2018; Thompson and Garbacz, 2008). Other studies (e.g., Koutroumpis, 2009) have emphasized the criticality of the development of broadband ${ }^{8}$ infrastructure for the exploitation of the advantages associated with other infrastructures (such as transportation, education, and remote sensing) that are necessary for economic growth. Jorgenson (2001) has argued that investment in information technology (IT) (e.g., computers, software, and communications equipment) enhances productive capacity in industries that use it. It also contributes to improving labour productivity and aggregate total factor productivity growth, in particular if there are spillovers from ITproducing industries to IT-using industries. Many studies have provided empirical support for the positive effect of broadband infrastructure and internet use (which could be proxies for development of ICT tools) on economic growth (e.g., Bacache et al. 2013; Bojnec and Ferto, 2012; Czernich et al., 2011; Holt and Jamison, 2009; Koutroumpis, 2009).

A number of studies (e.g., Barua et al., 2000; Cronin et al., 1993; Thompson and Garbacz, 2008; Van Gaasbeck, 2008) have nevertheless cautioned that the development of ICT tools might not necessarily result in higher economic growth. For example, the wide availability of broadband infrastructure, which is essential for ICT development including through greater access to the Internet, might not be conducive to economic growth if it did not lead to a total sectoral shift. The increased use of broadband infrastructure could also lead to a rise in self-employment, which although be associated with a rise in productivity, may induce a lower number of business establishments.

Summing-up, even though many studies have reported a positive effect of physical infrastructure development on economic growth, the effect might also be negative given that other factors matter for the positive effect to materialize. This means that the net effect of physical infrastructure on economic growth is an empirical matter.

\subsubsection{Effect of human capital on economic growth}

The effect of human capital ${ }^{9}$ on economic growth has been the subject of an immense literature. Earlier works (e.g., Arrow, 1962; Nelson and Phelps, 1966) have relied on the endogenous growth theory to show that human capital contributes to higher economic growth. Other following works by Romer (1986), Lucas (1988), Barro (1991), Mankiw et al. (1992), and Aghion and Howitt (1998) have underlined that human capital is an important determinant of per capita income. However, the empirical evidence on the effect of human capital on economic growth is inconclusive (e.g., Temple 2001). Some earlier studies have reported a positive effect of human capital on economic growth (e.g., Azariadis and Drazen, 1990; Bosworth and Collins, 2003; Lee, 2010; Romer, 1989). Others have reported that the effect of human capital - proxied for example by the level of education - on economic growth varies across countries and might not be always positive. It could in fact be weakly positive, not statistically significant, or even negative, depending on its effect on unemployment, wages, households' disposable income, the socializing role of human capital, including education, the way human capital itself has been measured, and possible endogeneity and estimations problems in the empirical analyses (e.g., Barro, 1991;

8 The OECD (OECD, 2001) has defined the concept of "broadband" as always-on internet access with transmission speeds equalling or exceeding $256 \mathrm{Kbps}$ for downstream connections and $64 \mathrm{Kbps}$ for upstream connections.

9 According to Becker (1964), human capital is the set of knowledge, skills, competencies, and abilities embodied in individuals and acquired, for example, through education, training, medical care, and migration. 
Benhabib and Spiegel, 1994; Bils and Klenow, 2000; Durlauf and Johnson, 1995; Gradstein and Justman, 2002; Krueger and Lindahl, 2001; Levine and Renelt, 1992; López-Bazo and Motelón, 2012).

Recently, Glewwe et al. (2014) and Benos and Zotou (2014) have reviewed the weaknesses of empirical studies (including the endogeneity concerns and estimation problems) on the effect of human capital on economic growth. Glewwe et al. (2014) have provided empirical evidence that education exerts a higher positive effect on economic growth in Sub-Saharan Africa (SSA) than in other countries, because of the lower school quality in SSA than in other countries. Benos and Zotou (2014) have applied a meta-regression analysis to 57 studies with 989 estimates, and obtained that there exist a substantial publication selection bias toward a positive impact of education on growth. Taking this weakness into account in their analysis, the authors have noticed that the observed positive impact of education on growth depends on several factors, including education measurement and studies' characteristics, such as model specification, type of data used, and the quality of research outlets where studies are published.

$\mathrm{Li}$ and Huang (2009) have found empirically that while both health and education have positive effects on economic growth in China, although there may be a trade-off between these two forms of human capital investment in influencing economic growth. Zhang and Zhuang (2011) have considered how the composition of human capital affects economic growth in China. Their findings indicate that the contribution of tertiary education to economic growth is higher than that of secondary education. Furthermore, the effect of the composition of human capital on regional economic growth in China depends on the regions' level of development, as provinces that are more developed benefit more from tertiary education, while underdeveloped ones rely more on primary and secondary education. According to Freire-Serén and i Martí (2013), the accumulation of human capital may adversely affect economic growth if it results in a rise in tax avoidance and a fall in effective tax rates and productive public investment. However, the interaction between human capital accumulation and tax avoidance generates economic growth and welfare effects. Ahsan and Haque (2017) have uncovered that schooling exerts a positive effect on economic growth only after the economy crosses a threshold level of development. McMahon (2018) has shown that the total return to higher education largely outweighs the opportunity cost of funds and the return on physical capital. In the author's analysis, the total return to higher education is the rate of return based on earnings plus non-monetary private and social benefits beyond earnings that captures higher education's contribution to development. Su and Liu (2016) have demonstrated empirically for China that human capital accumulation can contribute strongly to economic growth by acting as a facilitator for technology transfers stemming from FDI. Additionally, there is a strong FDI-human capital complementary effect for technology-intensive FDI than for labour-intensive FDI. Choi and Shin (2017) have used a computable overlapping generations model in which the accumulation of human capital is endogenous, and obtained that the mode of social transmission of human capital matters significantly for long-term growth of the economy.

Overall, while we can expect human capital accumulation to be positively associated with economic growth, it may also be possible that we obtain a negative effect human capital accumulation on economic growth. 


\subsubsection{Effect of natural resources on economic growth}

The literature on the economic growth effects of natural resources is very rich, and dates back to the 1990s (e.g., Auty, 2001; Bulte et al., 2001; Gylfason, 2006; Isham et al., 2005; Mavrotas et al., 2011). Many studies have indeed reported empirical evidence that abundance in natural resources (especially oil and gas) tends to be associated with a "resource curse", a phenomenon whereby the abundance in natural resources encumbers economic growth through a series of negative effects. Some authors (e.g., Ding and Field, 2005; Brunnschweiler and Bulte, 2008) have made a distinction between the concepts of "natural resource abundance" and "natural resource dependence", and provided empirical evidence that what really triggers the resource curse is the excessive dependence on natural resources or resource-based industries rather than the abundance in natural resources per se. While many studies have confirmed the resource-curse hypothesis, this negative effect may be mitigated or even turn out to be positive depending on several factors, including for example, the level of human capital accumulation and the institutional quality (e.g., Qiang and Jian, 2020; Zallé, 2019), whether there exist lower transports costs and encouragement of innovation (e.g., González-Vala and Pueyo, 2019), and if natural resource rents are used to promote export diversification, including through resource-based industrialization (e.g., Djimeu and Omgba, 2019; Massol and Banal-Estañol, 2014; Ross, 2019).

Overall, while productive resources (i.e., physical capital and resources accumulation) can exert a positive effect on economic growth, their ultimate effect can depend on many factors, as highlighted in the discussion above.

\subsubsection{Effect of institutional quality and entrepreneurial capabilities on economic growth}

It is now well established in the growth literature that good institutional quality is associated with a higher economic growth (e.g., Acemoglu and Johnson, 2005, 2010; Aron, 2000; Asfaw et al., 2020; Djankov et al., 2006; Siddiqui and Ahmed, 2013).

Entrepreneurial capabilities, which constitute another major component of productive capacities, could also influence economic growth. According to the UNCTAD (2006: 64), entrepreneurial capabilities include skills, as well as the knowledge and information available to enterprises to mobilize productive resources in order to transform inputs into outputs (and become competitive or enhance their competitiveness), invest, innovate, upgrade products and their quality, and even create markets. Entrepreneurial capabilities also refer to entrepreneurship and technological capabilities that shape the complex interaction of individual firm/farm with the macroeconomic environment (Lall, 1992, UNCTAD, 2018, 2020b). The impact of the private sector on economic growth seems to be well established in the literature. The private sector contributes to a higher economic growth through its investment (private investment) on the economy, the creation of employment, the provision of innovative goods and services, and its contribution to higher tax revenue. Brunetti et al. (1998) have shown that less credible rules result in lower rates of investment and growth. Credibility of rules entails the predictability of changes in laws and policies, the predictability of the reliability of law enforcement, of the impact of discretionary and corrupt bureaucracies, and of the danger of policy reversals due to changes in governments.

The private sector, including private firms, could spur economic growth through several avenues. First, private firms pay taxes to the government, and the resulting tax revenue could be 
used to increase the supply of goods and services needed to promote economic growth and development. Second, the investment by private firms contributes to the creation of jobs in the economy (e.g., Klein, 2003; Loc et al. 2006; Nalban and Smădu, 2021; Steer and Taussig, 2002). This means higher income for employees, which would consume domestically or import, and hence contribute to the increase in the economic growth rate. Third, the development of the private sector (i.e., the incentives for entrepreneurship and the resulting rise in the number of private firms) enhances competition, which improves efficiency and labour productivity. In turn, these may lead to lower prices and an efficient production process.

In the empirical literature, there seems to be a consensus that the development of entrepreneurial activities contributes to promoting economic growth. Marlow (1986) has shown that reducing the size of the private sector, does not only threats future overall economic growth, but it also constrains public sectors' future ability to consume private resources at accelerating rates. Many recent studies have uncovered a positive effect of entrepreneurship on economic growth (e.g., Almodovar-Gonzalez et al., 2019; García-Rodríguez et al., 2017; Gómez-Gras et al., 2011). Some studies (e.g., Audretsch, 2009; Fadahunsi and Rosa, 2002) have specifically found that generic entrepreneurship has exerted a positive effect on economic growth. Generic entrepreneurship is defined as "any action intended to start a business, regardless of its features, not related to any specific type of entrepreneurship" (Almodóvar, 2018: 226). Some other studies have questioned the positive effects of the entrepreneurial activity. For example, Desai et al. (2013) have argued that the analyses that have found positive effects of entrepreneurship on economic growth did not take into account the existence of destructive entrepreneurship. Carree and Thurik (2008) have underlined that the relationship between entrepreneurship and economic growth is far from being clear, while Liñán and Fernández-Serrano (2014) have stressed that the models underlying the effects of entrepreneurial activity on economic growth are far from being satisfactory. According to the findings by Ordeñana et al. (2019), growth-oriented entrepreneurship can strongly promote economic growth, including in developing countries. Relying mainly on the concept of "generic entrepreneurship", and using a sample of 74 countries over a period of 6 years, Almodóvar-González et al. (2020) have examined the factors that are related to both entrepreneurial spirit and economic growth. Their findings suggest that the effect of entrepreneurial activity on economic growth depends on the economic stage of the country in question. The authors have also concluded that less developed countries should not rely on generic entrepreneurship if they were to pursue the objective of promoting economic growth.

Overall, the direction of the effect of entrepreneurial activities on economic growth is an empirical issue.

\subsubsection{Effect of structural change on economic growth}

Production linkages are flows of goods and services, knowledge, technology and information, and productive resources (notably human resources) among productive units (firms/farms) in a given country. They also involve exchanges among firms/farms located in different sectors, and that have different sizes and ownership (domestic, foreign, public and private) (UNCTAD, 2020b). The development of production linkages (as defined above) is likely to be associated with a greater extent of structural change in production. 
There are many studies on the effect of structural change on economic growth. Structural transformation $^{10}$, also referred to as structural change (see Ray, 2010) can be viewed in a narrow sense - that is in terms of sectoral composition of the economy - as a reallocation of economic activity across three broad sectors (agriculture, manufacturing, and services) that accompanies the process of modern economic growth" (Herrendorf et al., 2014, p. 857). In a larger sense, structural change takes into account the development of the financial sector, demographic processes (e.g., changes in the patterns of fertility and the movement of women out of the household into the labor market), urbanization, migration, etc... (e.g., Greenwood and Seshadri, 2005). According to McMillan et al. (2014), structural change that involves the diversification away from agriculture into modern economic activities, also entails a movement of labor and other resources from agriculture into modern economic activities. This process induces an increase in the overall productivity, and an expansion of incomes, although the speed with which this structural transformation takes place is the key factor that explains why some countries succeed in terms of economic performance, and others not. McMillan et al. (2014) have obtained empirically that after 2000 , structural change has contributed positively to the overall productivity growth in Africa. They have concluded that the very low levels of productivity and industrialization in the majority of African countries represent an enormous potential for growth through structural change. Erumban et al. (2019) have reported a positive impact of static structural change on aggregate labor productivity growth, which was due to the movement of workers to sectors that enjoyed a relatively higher labor productivity level. In the same spirit, the work by Vu (2017) has established the importance of reforms to foster productivity-enhancing structural change, as well as the need for devising and implementing strategies to overcome their short-term costs in Asian economies. Lavopa and Szirmai (2018) have investigated the relationship between trajectories of structural modernisation and the ability of countries to escape poverty and middle-income traps (using a set of 114 countries over the period 1960 to 2014). One key finding of their analysis is that the expansion of the modern sector without a process of absorption of technology for reducing the technology gap would not suffice to ensure steady growth. In contrast, policies aiming at reducing the technology gap in some few sectors will produce an enclave economy that is doomed to stagnate. Overall, we expect a greater structural change to be associated with a higher economic growth.

In light of the discussion laid out under the sub-section 2.1, we postulate hypothesis 1 that even though few components of the overall productive capacities may not contribute to promoting economic growth, or may do so under certain circumstances, it is likely that the enhancement of productive capacities would spur economic growth in developing countries.

\subsection{Discussion on the effect of structural economic vulnerability on economic growth}

The effect of structural economic vulnerability on economic growth depends on how its components (namely the intensity of exposure to shocks and the intensity of exogenous shocks see Guillaumont, 2010) affect economic growth. Factors of exposure to shocks include the population size, remoteness from world markets, export product concentration, the output

10 Atolia et al. (2018) have discussed the potential benefits of structural transformation and the prospective future paths for structural transformation and development policies. 
dependence on agriculture, forestry and fishery; and the climate change risk, proxied by the share of population living in low elevated coastal zone. The intensity of shocks is a composite measure of the number of victims of natural disasters, the instability in the agricultural production, and the instability in exports of goods and services (see Feindouno and Goujon, 2016).

Structural economic vulnerability (which is a factor of instability) clearly influences negatively economic growth in developing countries. The various channels through which such a negative effect could take place have been largely discussed by Guillaumont (2010), and include factors of exposure to shocks and factors of shocks. Factors of exposure to shocks encompass smallness in terms of population size, high remoteness from the world markets, greater export product concentration, a strong output dependence on agriculture, forestry and fishery; and a high risk of climate change. On the other side, the negative economic growth effect of shocks can take place through lower total productivity growth, lower investment rates, an instability in investment, and instability in the real exchange rate. Other studies (e.g., Antonakakis and Badinger, 2016; Berg et al., 2011; Dabla-Norris and Gündüz, 2014; Junior et al., 2021; Loayza et al., 2007) have reported negative effects of adverse shocks on economic growth. Additionally, weather shocks and natural disasters (including severe ones) can adversely affect economic growth, through inter alia, lower investment, lower labor productivity, poorer human health, and lower agricultural and industrial output (e.g., Acevedo et al., 2020; Alba et al., 2011; Fomby et al., 2013; Gavin and Hausmann, 1998; Kalkuhl and Wenz, 2020; Klomp and Valckx, 2014; Loayza et al., 2012). Nevertheless, moderate disasters (such as moderate floods) can have a positive economic growth effect in some sectors (see Fomby et al., 2013; Loayza et al., 2012).

Despite the large number of studies on the effects of shocks on economic growth, there have so far been few empirical works on the effect of structural economic vulnerability (as defined above) on economic growth. Cordina (2004) has obtained that, at the steady state, the allocation of resources to counteract vulnerability allows more vulnerable countries to experience a higher per capita capital stock and output, but a lower per capita consumption level. However, in a dynamic setting, vulnerability reduces the speed of convergence between economies at different stages of development. Guillaumont and Wagner (2012) have reported evidence that while higher levels of structural economic vulnerability can reduce the chances (probability) of growth accelerations in developing countries, development aid appears to exert a positive effect on the probability of occurrence of growth spells and on the duration of these spells in countries that experience a high level of structural economic vulnerability. Along the same lines, Wagner (2014) has found that the level of economic vulnerability is critical in understanding how economic growth responds to aid flows, as aid exerts a higher positive effect on economic growth in highly vulnerable countries.

In light of the foregoing, we postulate hypothesis 2 that an increase in structural economic vulnerability would lead to lower economic growth, although such a negative effect may appear only above a certain level of structural economic vulnerability.

\subsection{Joint effect of productive capacities and structural economic vulnerability on economic growth}

We have made above two hypotheses: the first one is that enhancing productive capacities is likely to generate higher economic growth rates. The second hypothesis postulates that an 
increase in the degree of structural economic vulnerability would reduce economic growth. Given that developing productive capacities could themselves contribute to lowering structural economic vulnerability (as through the strengthening of resilience to shocks), we postulate that the strengthening of productive capacities can promote economic growth in countries that experience a high degree of structural economic vulnerability (hypothesis 3).

\section{Discussion on the effect of productive capacities and structural economic vulnerability on economic growth volatility}

\subsection{Effect of productive capacities on economic growth volatility}

In light of the definition of productive capacities laid out above, it seems straightforward that countries that develop and/or enhance their productive capacities are likely to enjoy lower economic growth volatility. In fact, each of the three dimensions of the overall productive capacities (namely, productive resources, entrepreneurial capabilities and production linkages) are likely to influence directly or indirectly economic growth volatility.

\subsubsection{Effect of physical capital on economic growth volatility}

The development of physical capital (e.g., energy, transport or ICT) would help reduce trade costs, and promote export product diversification. For example, Iwanow and Kirkpatrick (2009) have reported a positive effect of trade facilitation on bilateral exports of manufactured products. In a similar spirit, Shepherd (2010) has found that trade costs in general, and in particular, export costs, tariffs, and international transport costs are robustly associated with geographical export diversification in developing nations. These positive effects of trade costs reduction appear to be larger in manufacturing, and highly differentiated sectors. Likewise, Dennis and Shepherd (2011) have shown empirically that an improvement in trade facilitation ${ }^{11}$ can lead to export diversification gains of 4 and 3 per cent, respectively in developing countries. Regolo (2013) has demonstrated theoretically and empirically that very low bilateral trade costs contribute significantly to export diversification, notably in countries that have similar endowments (physical capital, land and human capital endowments per worker) with their trading partners. Persson (2013) uncovered empirically that trade facilitation, measured by the number of days needed to export, exerts a higher positive effect on the export of differentiated products than on the export of homogeneous products. The findings by Feenstra and Ma (2014) indicate that greater port efficiency has a positive impact on export variety. Beverelli et al. (2015) have observed that by reducing both variable and fixed trade costs, trade facilitation exerts a positive effect on the extensive margins of trade, i.e., the number of products exported by destination and the number of export destinations served by-products. Additionally, substantial gains associated with trade facilitation accrue to SubSaharan Africa, Latin America and the Caribbean countries.

On another note, ICTs have been shown to exert a strong positive effect on export product diversification including both at the intensive and extensive margins of exports (e.g., Abeliansky et al., 2021), services export diversification (e.g., Gnangnon, 2020) and export sophistication (e.g.,

11 This involves lowering the costs of international transport, and reducing domestic exporting costs, i.e., the costs associated with the documentation, inland transport, port and customs charges. 
Lapatinas, 2019). As export diversification and export sophistication could help dampen output volatility (e.g., Haddad et al. 2013; Kramarz et al. 2020; Malik and Temple, 2009; Vannoorenberghe et al. 2016), we can expect that by reducing trade costs and hence promoting export product diversification, the development of physical (hard) infrastructure as well as the promotion of ICT would contribute to lowering economic growth volatility.

\subsubsection{Effect of human capital on economic growth volatility}

Human capital accumulation could also influence economic growth volatility. More generally, complex goods, i.e., sophisticated goods are those that have a high knowledge content, i.e., those with a high human capital intensity, (e.g., Bustos et al., 2012; Hausmann and Hidalgo, 2009; Hausmann and Hidalgo, 2011; Hidalgo, 2009). Additionally, some studies (e.g., Güneri and Yalta, 2020; Maggioni et al., 2016; Miranda-Pinto, 2021) have obtained empirically that complex economies $^{12}$ experience lower economic growth fluctuations, or lower economic growth cycles (e.g., Canh and Thanh, 2020).

In particular, the effect of human capital accumulation on economic growth volatility can take place through its effect on export product diversification. In fact, human capital can promote export diversification (e.g., Agosin et al., 2012; Andersson and Johansson, 2010; Jetter and Hassan, 2015), including through its effect on innovation (e.g., Lenihan et al., 2019; Mariz-Perez et al., 2012; Sun et al., 2020). For example, concerning the direct effect of human capital on export diversification, Jetter and Hassan (2015) have tried to identify the true determinants of export diversification among 36 potential factors. They have observed that primary school enrolment ranks as the first main determinant of export diversification. They have then concluded that basic education coverage is essential for export diversification, at least in the long run. Andersson and Johansson (2010) have also obtained that cross-regional variations in human capital influence both the extensive margin (i.e., the number of export products) and the intensive margin (average export value per product). Concerning the indirect effect of human capital on export diversification through the innovation channel, Sun et al. (2020) have relied on China's firm-level data, and shown that highly educated human capital stock exerts a strong positive effect on the probability and the quantity of firm innovation. The importance of human capital accumulation for innovation has also been emphasized by authors such as Fonseca et al. (2019), while that of innovation for export product diversification has been stressed by Chen (2013).

Summing-up, we expect that human capital development would be associated with lower economic growth volatility if it contributes to the diversification of the export product baskets. Otherwise, it would be associated with a higher economic growth volatility, in particular if it induced a concentration of exports on low value-added products.

\subsubsection{Effect of natural capital on economic growth volatility}

Natural resource dependence also influences economic growth volatility through its effect on export diversification. In fact, a high dependence of an economy on natural resources may be associated with a less diversified export products basket (e.g., Djimeu and Omgba, 2019; Jetter and Hassan, 2015; Ross, 2019), which in turn, raises countries' vulnerability to external shocks, and

${ }^{12}$ Complex economies are those featured by a sophisticated productive structure, i.e., with a high diversity of the goods exported, and a low ubiquity of these products (i.e., a few number of countries that also export these products) (e.g., Hausmann and Hidalgo, 2009). 
ultimately induces greater economic growth volatility (e.g., Haddad et al. 2013; Kramarz et al. 2020; Malik and Temple, 2009; Vannoorenberghe et al. 2016). Jetter and Hassan (2015) have obtained that the share of natural resources in gross domestic product is the second major determinant of export diversification (it negatively affects export product diversification) among the 36 potential factors explored. Djimeu and Omgba (2019) have reported that the effect of oil windfalls on export product diversification process depends on the country's export structure before the oil boom: the lower the initial levels of export diversification before the oil boom, the higher is the negative effect of oil boom on the export product diversification process. Ross (2019) has identified that among oil producers, there are relatively few cases of successful diversification, and in Africa, no case has been identified. Overall, the natural resource dependence is expected to be positively associated with economic growth volatility.

The other components of the overall productive capacities - namely entrepreneurial capabilities, institutional quality and structural change in production - can also exert an impact on economic growth volatility.

\section{volatility}

\subsubsection{Effect of the development of the private sector on economic growth}

The development of the private sector, which reflects higher opportunities for entrepreneurship, may affect economic growth volatility. While many studies have looked at the effect of entrepreneurial activities on economic growth, scarce studies have investigated the effect of entrepreneurial activities on the volatility of economic growth. One of these rare studies is that of Rampini (2004). The author has developed a model, which postulates that entrepreneurial activity is likely to develop in more productive economies, as the latter help agents be in a better capacity to share project-specific risks. The model predicts that when the domestic financial market is less developed in an economy (in such an economy, agents have to bear all the project-specific risk), the economy may experience more volatile output and lower output. Thus, an entrepreneurial activity can have a first-order effect on output, in particular if economic agents are indifferent between the riskless and the risky projects, and if the resulting expected output of the risky projects exceeds the output of the riskless projects so as to compensate agents for risk. Against this background, we can expect that the development of the private sector would contribute to dampening economic growth fluctuations.

\subsubsection{Effect of the institutional quality on economic growth volatility}

Acemoglu et al. (2003) have put forth a number of reasons as to why economies with weak institutional quality are likely to experience a higher volatility of output. Such economies are more likely than those with strong institutions to fail in dealing with external economic shocks. Additionally, economies featured by low institutional quality are exposed to higher levels of social unrest, disrupting growth. Finally, in countries with weak institutions, rent seeking behavior is encouraged, and this can potentially result in a proliferation of bad policy implementation, and greater volatility. Acemoglu et al. (2003) have provided empirical evidence that differences in the quality of institutions contribute significantly to explaining the large cross-country differences in economic volatility. Other empirical studies have confirmed that improvements in the institutional quality contribute to lowering output volatility (e.g., Balavac and Pugh, 2016; Ghosh, 2013; McConnell and Perez-Quiros, 2000). 


\subsubsection{Effect of structural change on economic growth volatility}

The dampening effect of structural change in production on economic growth volatility may also be obvious. Indeed, as we noted above export product diversification generates lower economic growth volatility. At the same time, Saltarelli et al. (2020) have used the World InputOutput Database (WIOD) to investigate the extent to which export is a proxy for domestic production, and found that export mirrors very well domestic production for manufacturing sectors or sectors related to physical goods, while for services, the relationship is less strong for the services sector. Therefore, in light of the negative effect of export product diversification on output volatility (see above), we could conjecture that the change in the structure of production away from primary products towards manufactured products is likely to induce lower fluctuations of output. Yet, structural change can also entail the change in the structure of production towards both the manufacturing and services sectors, and Moro (2015) has demonstrated that the expansion of the services sector lowers economic growth volatility. Surprisingly, Harchaoui (2019) has observed that macroeconomic volatility declines with development in developing countries only where structural transformation is ruled out.

In light of the whole discussion carried out under sub-section 3.1, we postulate hypothesis 4 that greater productive capacities are likely to help reduce the fluctuations of economic growth, i.e., economic growth volatility. In other words, we expect greater productive capacities to contribute to ensuring the stability of economic growth.

\subsection{Effect of structural economic vulnerability on economic growth volatility}

There is a voluminous literature on the fact that macroeconomic shocks are important drivers of economic fluctuations, including output volatility (e.g., Alba et al., 2011; Antonakakis and Badinger, 2016; Loayza et al. 2007; Raddatz, 2007; Ramey, 2016; Rasaki and Malikane, 2015). However, we are not aware of a published study on the effect of structural economic vulnerability (as defined in the present study) on economic growth volatility in developing countries.

We discuss the effect of structural economic vulnerability on economic growth volatility taking each component of the index of structural economic vulnerability. The effect of structural economic vulnerability on economic growth volatility depends on how the intensity of exposure to shocks and the intensity of shocks affect economic growth volatility.

An important body of the literature has documented that large countries are likely to have more inertia in output, and smaller countries tend to experience sharper fluctuations (e.g., Alouini and Hubert, 2019; Crucini, 1997; Easterly and Kraay, 2000; Furceri and Karras, 2007; Imbs, 2007). For example, Easterly and Kraay (2000) have shown that smaller economies experience a higher output volatility (although also higher economic growth) due to their greater volatility of terms of trade shocks, such a volatility being explained by their higher level of trade openness. According to Imbs (2007), there is a negative relationship between countries' size and output volatility because large countries tend to have a large number of sectors, which help to mitigate output fluctuations. Furceri and Karras (2007) have shown that trade openness explains the inverse relationship between country size and output volatility. Alouini and Hubert (2019) have also reported empirical evidence that the rise in the country size measured by a composite index of population, GDP and arable land, exerts a negative effect on output volatility. Thus, we can expect that the rise in the 
population size - which is the first element of the 'exposure to shocks' component of structural economic vulnerability, would reduce economic growth volatility.

On the other side, Malik and Temple (2009) have demonstrated that remote countries tend to have undiversified exports, and to experience greater output growth volatility. We can, therefore, expect that a higher remoteness from the world markets would be associated with greater economic growth volatility. The positive economic growth volatility effect of export product concentration in developing countries has been highlighted by many empirical studies, the argument being that greater export product concentration, notably on primary commodities exposes countries to external shocks, and hence induces greater economic growth volatility (e.g., Haddad et al. 2013; Malik and Temple, 2009; Kramarz et al. 2020; Vannoorenberghe et al. 2016). Similarly, Joya (2015) has shown that the diversification of production structure, including in resource-rich countries, contributes to mitigating the economic growth volatility induced by the dependence on natural resources. Moro (2015) has found that the sectoral composition of output matters for output volatility. Specifically, a rise in the share of services in GDP results in a fall in both aggregate total factor productivity growth and volatility, thus reducing GDP growth and volatility. Similarly, Moro (2012) has obtained that structural change generates a decline in the volatility of both aggregate TFP and GDP, the volatility of each broad component of GDP (manufacturing consumption, services consumption and investment) and the volatility of labor. In a similar vein, Ngouana (2013) has uncovered that the secular shift of labor towards the service sector was volatility-reducing in OECD countries during 1970-2006. Therefore, we expect that the higher the share of agriculture, forestry and fishery production in GDP (i.e., the lower the share of manufacturing and services production in GDP), the higher would be the level of economic growth volatility.

Finally, countries with a high risk of climate change (proxied by the share of population living in low elevated coastal zone) are likely to be greatly prone to climate shocks, which in turn, can induce output volatility. Thus, we can anticipate that greater exposure to shocks would lead to greater volatility of economic growth.

As already noted, shocks (including external shocks taking the form of instability in the agricultural production and the instability in exports of goods and services) are associated with greater output volatility.

Against the backdrop of the discussion under sub-section 3.2, we postulate hypothesis 5 that an increase in the level of structural economic vulnerability would likely be associated with a higher volatility of economic growth in developing countries.

\subsection{Joint effect of productive capacities and structural economic vulnerability on economic growth}

Hypothesis 4 postulates that productive capacities would reduce economic growth volatility, while hypothesis 5 provides that structural economic vulnerability would enhance the volatility of economic growth. Given that the development of productive capacities is likely to contribute to reducing the level of structural economic vulnerability in developing countries, we can expect that greater productive capacities would help dampen economic growth volatility, particularly in countries that face a high degree of structural economic vulnerability (hypothesis 6). 


\section{Model specifications}

Building on the extensive (and well-known) literature on the macroeconomic determinants of economic growth on the one hand, and on the macroeconomic determinants of economic growth volatility, on the other hand, we postulate two different baseline model specifications. The first baseline model (model (1)) allows investigating the effect of productive capacities on economic growth, and whether this effect depends on the level of structural economic vulnerability in the country. The second model (model (2)) allows assessing the effect of productive capacities on the volatility of economic growth, and whether this effect depends on the level of structural economic vulnerability in the country.

The baseline model (1) takes the following form:

$$
\begin{aligned}
& \text { GROWTH }_{\text {it }}=\alpha_{1} \text { GROWTH }_{\text {it }-1}+\alpha_{2} \text { PCI }_{\text {it }}+\alpha_{3} \text { EVI }_{i t}+\alpha_{3} \text { EVI It }_{i t}^{2}+\alpha_{4} \text { GCONS }_{i t}+ \\
& \alpha_{5} \text { FINPOL }_{i t}+\alpha_{6} \text { ODA }_{\text {it }}+\alpha_{7} \text { OPEN }_{\text {it }}+\alpha_{8} \text { INFL }_{i t}+\alpha_{9} \text { TERMS }_{i t}+\mu_{\mathrm{i}}+\gamma_{\mathrm{t}}+\omega_{\mathrm{it}}
\end{aligned}
$$

The baseline model (2) takes the following form:

$$
\begin{aligned}
& \log (\mathrm{GRVOL})_{\mathrm{it}}=\beta_{1} \log (\mathrm{GRVOL})_{\mathrm{it}-1}+\beta_{2} \log (\mathrm{PCI})_{\mathrm{it}}+\beta_{3} \log (\mathrm{EVI})_{\mathrm{it}}+\beta_{4} \log (\mathrm{GDPC})_{\mathrm{it}}+ \\
& \beta_{5} \mathrm{OPEN}_{\mathrm{it}}+\beta_{6} \mathrm{FINOL}_{\mathrm{it}}+\beta_{7} \log (\mathrm{ODAVOL})_{\mathrm{it}}+\beta_{8} \log (\mathrm{INFLVOL})_{\mathrm{it}}+\beta_{9} \log (\mathrm{TERMSVL})_{\mathrm{it}}+ \\
& \varepsilon_{\mathrm{i}}+\vartheta_{\mathrm{t}}+\tau_{\mathrm{it}}
\end{aligned}
$$

The panel dataset used to conduct the empirical analysis contains 117 developing countries over the period 2000-2018, based on data availability ${ }^{13}$. Non-overlapping sub-periods of 3-year intervals (2000-2002; 2003-2005; 2006-2008; 2009-2011; 2012-2014 and 2015-2018 ${ }^{14}$ ) have been used in the analysis in order to mitigate the influence of business cycles on variables at hand.

$i$ and $t$ represent respectively the subscript for countries, and the time-periods listed above. $\alpha_{1}$ to $\alpha_{9}$, and $\beta_{1}$ to $\beta_{9}$ are parameters that would be estimated. $\mu_{\mathrm{i}}$ and $\varepsilon_{\mathrm{i}}$ are countries' specific effects in models (1) and (2). $\gamma_{\mathrm{t}}$ are temporal dummies that act for global shocks influencing economic growth simultaneously in all countries. $\vartheta_{t}$ are temporal dummies. $\omega_{i t}$ and $\tau_{i t}$ are random error terms.

In model (1), the dependent variable "GROWTH" is the real economic growth rate (in percentage). In model (2), the dependent variable "GRVOL" is the volatility of the economic growth rate. It is calculated as the standard deviation (rolling window) of the economic growth rate over a three-year-window (see Bayraktar, 2019; Bekaert et al. 2006; Ebeke and Ehrhart, 2012; Museru et al., 2014 who have also used this approach to compute the volatility of their relevant variables). The one-period lag of the dependent variables are introduced in models (1) and (2) in order to account for the inertia respectively in economic growth and economic growth volatility.

Our key variables of interest in the analysis, "PCI" and "EVI", represent respectively the indicator of overall productive capacities, and the indicator of structural economic vulnerability. The indicator "PCI" is developed by the UNCTAD (see UNCTAD, 2020) and computed as a geometric average of eight domains or categories, namely, information communication and

${ }^{13}$ Data on the productive capacities is available only from 2000 to 2018, which has constrained us to limit the time-period of the study to that period.

${ }^{14}$ Note that the last non-overlapping sub-period (which is, 2015-2018) covers 4 years. 
technologies, structural change, natural capital, human capital, energy, transport, the private sector and institutions. Each category index is obtained using the principal components extracted from the underlying indicators, weighted by their capacity to explain the variance of the original data. The category indices are normalized into 0-100 intervals. The components of "PCI" are ICTs (denoted "ICT"), structural change (denoted "SCI"), natural capital (denoted "NATCAP"), human capital (denoted "HUMCAP"), energy (denoted "ENERG"), transport (denoted "TRANSP"), the private sector (denoted "PRIVATE"), and institutions (denoted "INST").

The indicator "EVI" is developed by the United Nations Committee for Development Policy (CDP), and used by the latter as one of the criteria for identifying LDCs. The "EVI" has been computed as the simple arithmetic average of two sub-indexes, namely the intensity of exposure to shocks (exposure sub-index) and the intensity of exogenous shocks (shocks subindex). These two sub-indexes have, in turn, been calculated using a weighted average of different component indexes, with the sum of components' weights being equal to 1 so that the values of EVI range between 0 and 100 (see for example Feindouno and Goujon, 2016).

We find useful to emphasize that for the sake of the analysis (including to facilitate the interpretation of estimates), we have re-scaled the variable "EVI" in model (1) by dividing it by 100. However, for model (2), we have used the EVI variable as it stands, i.e., without dividing it by 10 .

The squared term of "EVI" has been introduced in model (1) in light of the observation in Figure 5 (see below) that there can be a non-linear relationship (including in the form of an inverted U-curve) between structural economic vulnerability and economic growth.

Control variables in model (1) include the government consumption (\% GDP) denoted "GCONS"; the index of financial openness (i.e., capital account openness) denoted "FINPOL"; the real gross disbursements of the official development assistance, expressed in constant 2018 US\$ prices, and denoted "ODA"); the trade openness indicator ("OPEN"); the transformed indicator of the inflation rate (denoted "INFL") in order to reduce its skewness (see Appendix 1 for details on the transformation of the inflation rate variable); and the index of terms of trade ("TERMS").

With regard to model (2), the controls "INFLVOL", "ODAVOL" and "TERMSVOL" represent respectively the volatility of the inflation rate, development aid volatility, and the volatility of terms of trade. The inflation rate volatility has been calculated as the standard deviation (rolling window) of the inflation rate over a three-year-window. The volatility of development aid, and the terms of trade volatility have been calculated respectively as the standard deviation (rolling window) of the growth rate of development aid, and the growth rate of terms of trade, over a three-year-window.

All variables contained in model (2) - with the exception of "OPEN" and "FINPOL" - have been transformed using the natural logarithm. The purpose of doing so is not only to reduce the skewness of many of those variables, but also to obtain coefficients in terms of elasticity. In particular, the natural logarithm has not been applied to the variable "OPEN" because it is expressed in terms of ratio. The indicator "FINPOL" contains some zeros, its values between 0 and 1 , and its distribution is not skewed. Therefore, we have not transformed it using the natural logarithm. 


\section{What is the message conveyed by data?}

This section presents an analysis of data concerning our key variables of interest, namely the indicator of the overall productive capacities, the index of structural economic vulnerability, as well as economic growth and its volatility indicators. The analysis uses using non-overlapping subperiods data, and focuses on the full sample and two sub-samples, namely LDCs and other countries in the full sample, referred to as NonLDCs. The choice to focus on these two subsamples is dictated by the fact that while the literature has stressed the importance of strengthening productive capacities in developing countries, a special emphasis has been put on LDCs, as these countries do not only have low levels of productive capacities (including compared to NonLDCs), but they also exhibit a high degree of structural economic vulnerability (even compared to NonLDCs) (e.g., UNCTAD, 2020a, 2020b).

Figure 1 depicts the development of these four indicators over the full sample, while Figures 2 and 3 do the same for the sub-samples of LDCs and NonLDCs.

Figure 4 shows the cross-plot between productive capacities and economic growth over the full sample and the two sub-samples, while Figure 5 displays the correlation pattern (in terms of linear and non-linear relationships) between structural economic vulnerability and economic growth over the full sample.

Figure 5 displays the cross plot between the index of overall productive capacities, the indicator of structural economic vulnerability and the indicator of economic growth volatility over the full sample and sub-samples of LDCs and NonLDCs.

In Figure 6, we present the cross plot between productive capacities, structural economic vulnerability and economic growth volatility over the full sample and the two sub-samples.

\section{[Insert Figure 1, here] [Insert Figure 2, here]}

Figure 1 shows that productive capacities have steadily increased over time in the full sample, moving from 24.5 in 2000-2002 to 28.8 in 2015-1028. This trend indicates that on average, developing countries have strengthened their productive capacities over time. At the same time, the level of structural economic vulnerability has been steadily declining, from 34.4 in 2000-2002 to 31.5 in 2015-2018. Economic growth appears to have fluctuated over the period: it has increased from $1.95 \%$ in $2000-2008$ to $3.9 \%$ in $2006-2008$, and then suddenly declined to reach $2 \%$ in 2009 2011, probably due to the 2008-2009 financial crisis. It has subsequently increased to reach $2.7 \%$ in 2012-2014, before falling to $1.7 \%$ in 2015-2018. The magnitude of these fluctuations are reflected in the red line of Figure 1. It appears that the level of economic growth volatility has slightly declined from 2.7 in 2000-2002 to 2.1 in 2006-2008. It has then moved upward to reach 3.1 in 2009-2011 before exhibiting a declining trend over the rest of the period.

\section{[Insert Figure 3, here]}

Figure 3 (which concerns NonLDCs) shows patterns that are similar to those observed in Figure 1, whereas patterns observed in Figure 2 (concerning LDCs) are slightly different from the ones in Figure 1. In particular, we note in Figure 2 that the level of productive capacities has strongly increased in NonLDCs from 26.3 in 2000-2002 to 31.3 in 2015-2018. At the same time, productive capacities remain at a lower level in LDCs than in NonLDCs, and have also substantially increased slightly increased in LDCs, from 19.9 in 2000-2002 to 31.3 in 2015-2018 (see Figure 2). The degree of structural economic vulnerability is far higher in LDCs than in 
NonLDCs, even though it has slightly fallen over time in both sub-samples. EVI has decreased from 30.4 in 2000-2002 to 28.3 in 2015-2018 in NonLDCs, while in LDCs, it has declined from 42.3 in 2000-2002 to 38.4 in 2015-2018. As noted above, the development of economic growth and economic growth volatility in NonLDCs shows patterns similar to those observed in Figure 1. Specifically, Figure 3 indicates that, in NonLDCs, economic growth has increased from $2.2 \%$ in $2000-2008$ to $4 \%$ in 2006-2008, followed by a decline to $1.7 \%$ in 2009-2011, and then a rebound to $2.7 \%$ in 2012-2014. Finally, from 2012-2014 to 2015-2018, economic growth has decreased to $1.7 \%$. LDCs have experienced a strong increase in economic growth from 1.4\% in 2000-2008 to $3.7 \%$ in 2006-2008, and then exhibited a downward path to reach 1.8\% in 2015-2018 (see Figure 2). Lastly, the degree of economic growth volatility has been higher in LDCs than in Non-LDCs, from 2000-2008 to 2006-2008. However, from 2006-2008 to 2012-2014, the level of economic growth volatility has become lower in LDCs than in NonLDCs, although towards the end of the period, economic growth has become much more stable in both LDCs and NonLDCs.

\section{[Insert Figure 4, here] \\ [Insert Figure 5, here]}

We note from Figure 4 that while the correlation between productive capacities and economic growth is not clear-cut over the full sample and NonLDCs, in LDCs, productive capacities are positively correlated with economic growth. However, there are some outliers in the graphs of Figure 4. The direction of the linear correlation pattern between structural economic vulnerability and economic growth on the left-hand side graph of Figure 5 is not clear. However, the right-hand side graph of the same Figure indicates the existence of a nonlinear relationship in the form of an inverted U-curve - between structural economic vulnerability and economic growth over the full sample. Nevertheless, both graphs in Figure 5 suggest the presence of some outliers. Outliers in Figures 4 and 5, as well as the non-linear relationship between EVI and economic growth will be taken into account in the empirical analysis.

\section{[Insert Figure 6, here]}

Figure 6 indicates a slightly negative correlation pattern between the overall productive capacities and economic growth volatility, but a strong positive association between structural economic vulnerability and economic growth volatility over the full sample. For LDCs, we observe a strong negative correlation between the overall productive capacities and economic growth volatility, and a strong positive correlation between structural economic vulnerability and economic growth volatility. Similar patterns, although in a lesser strong way, are observed for NonLDCs. On another note, some few outliers appear in the graphs of Figure 6. The empirical analysis will take into account these outliers.

\section{Empirical strategy}

This section discusses the econometric approaches used to estimate the baseline models (1) and (2) as well as their different variants discussed below.

We use the within fixed effects (FE) and the feasible generalized least squares (FGLS) as first estimators to estimate the baseline models (1) and (2) where all regressors, except for the variable representing the terms of trade, have been considered with a one-period lag so as to mitigate any possible endogeneity problem (notably in the form of reverse causality). The outcomes of these estimations are displayed in Table 1 (for model (1)) and Table 5 (for model (2)). 
However, using the one-period lag of the suspected endogenous regressors might not fully address the endogeneity problem in the form of reverse causality, and estimates might still be biased. Moreover, the correlation between the one-period lagged dependent variable and countries' specific effects is likely to introduce the Nickell bias (see Nickell, 1981), which is specific to panel datasets with small time-period and large cross-sections.

We then move on to estimate the baseline models (1) and (2) using the two-step system Generalized Methods of Moments (GMM) estimator developed by Blundell and Bond (1998). This estimator is our main estimator in the present analysis. It applies to panel datasets with relatively limited time horizon and large individual observations, helps to handle unobserved country heterogeneity, omitted variable bias, measurement error and potential endogeneity. This technique is now largely utilized in the macro-empirical literature, and combines in a system of equations (for each model (1) and (2) considered separately) the relevant equation in firstdifferences and in the levels. Lagged first differences are used as instruments for the levels equation, and lagged levels are used as instruments for the first-difference equation. Using this types of instrumental variables allows for addressing the potential endogeneity biases and, the system of equations permitted by the two-step system GMM estimator helps to reduce the potential bias and imprecision arising from a simple-first difference estimator (Arellano and Bover, 1995; Blundell and Bond, 1998).

In models (1) and (2), one endogeneity bias stems from the presence of the one-period lag dependent variable as a right-hand side regressor, including its correlation with countries' specific effects. The 'naïve' estimation of these dynamic models by the ordinary least squares estimator, the FE or FGLS estimators would lead to a bias in the coefficient of the lagged variable (i.e., the Nickell bias - see Nickell, 1981). Another endogeneity problem arises from the reverse causality links between several regressors and the dependent variable in both models (1) and (2). Specifically, in model (1), regressors that can be suspected as endogenous (i.e., suffering from the reverse causality issue) can be the variables representing the productive capacities, structural economic vulnerability, financial openness, government consumption, development aid, trade openness and inflation.

For example, countries that wish to spur their economic growth can make efforts to enhance their productive capacities, reduce the structural vulnerability of their economies, and modulate their level of financial openness. Likewise, the reverse causality from the dependent variable to government consumption, development aid, trade openness, and inflation have been well emphasized in the empirical literature. Considering model (2), reverse causality issues can potentially concern the variables capturing productive capacities, structural economic vulnerability, the real per capita income, financial openness, development aid volatility, trade openness and inflation volatility. Countries that face high levels of output volatility may be willing to develop their productive capacities so as to reduce their vulnerability and enhance their resilience to shocks. Similarly, countries whose output fluctuates severely due to their high structural economic vulnerability are likely to develop strategies and policies to reduce such vulnerability to shocks. These types of countries may also experience a high volatility of aid disbursed by donors because such aid would be unexpectedly disbursed by donors to meet the adverse effects of negative shocks in beneficiary countries.

The literature on the determinants of output volatility (see studies cited above) have also emphasized the endogeneity problem associated with the real per capita income, financial 
openness, trade openness and inflation volatility in model specifications on the determinants of output volatility.

Three criteria are used to evaluate whether the baseline models (1) and (2) and their different variants are correctly specified. These include the Arellano-Bond test of first-order serial correlation in the residuals of the equations in level (denoted AR(1)), the Arellano-Bond test of no second-order autocorrelation in the residual in the differenced equation (denoted $\operatorname{AR}(2)$ ), and the Sargan/Hansen test of over-identifying restrictions (OID), whose null hypothesis is the instrument validity. In addition, we ensure in all regressions that the number of instruments is lower than the number of countries.

Using the two-step system GMM approach, we estimate the baseline models (1) and (2), and several variants of each of these models that we describe now.

Concerning model (1), we start with the estimation of the baseline model (1) (without ${ }^{15}$ the squared term of "EVI"), and presented the results of this estimation in column [1] of Table 1. The outcomes of the estimation of model (1) as it stands, (that is, with both the "EVI" and its squared term) are presented in column [2] of Table 2. Results in column [3] of Table 2 are obtained by taking into account the few outliers observed in the graphs of Figures 4 and 5. Here, we estimate the baseline model (1) that include the dummy variable ${ }^{16}$ capturing the outliers presented in Figures 4 and 5 (over the full sample), and the interaction of this dummy with "PCI", "EVI" and the squared term of "EVI". It is important to note that all subsequent regressions whose outcomes are presented in Tables 3 and 4, take into account these outliers.

Column [4] of Table 2 contains the outcomes that help to examine the effect of productive capacities on economic growth in LDCs and NonLDCs. Regressions performed here concern model (1) that includes a dummy variable "LDC" (which takes the value "1" for LDCs, and "0", otherwise) and its interaction with the variable "PCI".

The upper part of Table 3 contains outcomes that allow exploring how each component of the variable measuring the productive capacities, influences economic growth over the full sample. These outcomes are obtained by estimating several variants of model (1) where we replace the variable "PCI" with each of its components (each component is included once in the model). The lower part of Table 3 provides results that allow investigating how each component of "PCI" influences economic growth in LDCs versus NonLDCs in the full sample. These results are obtained by estimating different other specifications of model (1) that contain the dummy "LDC", each component of "PCI" (introduced once in the model) and the interaction between each of these components and the "LDC" dummy.

Finally, we report in Table 4 the outcomes that allow considering how productive capacities and structural economic vulnerability interact in affecting economic growth path in developing countries. To obtain these outcomes, we estimate a specification of model (1) that contains the interaction between "PCI" and "EVI", and well as the interaction between "PCI" and the squared term of "EVI".

15 We have excluded, in the first instance the squared term of "EVI" from the baseline model in order to explore how structural economic vulnerability influences economic growth in a linear way.

${ }^{16}$ This dummy is related to outliers observed in graphs (over the full sample) of Figures 4 and 5 concerning the correlation pattern between economic growth rate, productive capacities and structural economic vulnerability. The dummy takes the value 1 for outlier-countries and 0 , otherwise. It is important to underline that the same outliers have been identified for the graphs that relate "GROWTH" with "PCI" on the one hand, and "GROWTH" with "EVI", on the other hand. 
We now turn to the presentation of the different specifications of model (2) estimated with the two-step system GMM estimator. Column [1] of Table 5 shows the estimates associated with the estimation of the baseline model (2) as it stands. Column [2] of the same Table presents the results of the estimation of a variant of model (2) that takes into account the few outliers observed in the graphs of Figure 6. To uncover these outcomes, we estimate a specification of the baseline model (2) in which we introduce a dummy variable ${ }^{17}$ capturing the outliers, and its interactions respectively with "PCI" and "EVI". All subsequent regressions whose results are reported in Tables 6 to 8 take into account these outliers along with its interaction with "PCI" as well as "EVI".

In column [3] of Table 6, we report estimates that help to examine the effect of productive capacities and structural economic vulnerability on economic growth volatility in LDCs versus NonLDCs. These outcomes are obtained by estimating a variant of model (2) that include both the LDC dummy and its interaction with "PCI" and "EVI".

Table 7 contains, in its upper part, the outcomes arising from the estimation of several specifications of model (2), where we replace the indicator of the overall productive capacities with each of its components. The lower part of Table 7 reports outcomes that permit to assess the effect of each component of the overall productive capacities on economic growth volatility in LDCs versus Non-LDCs. Regressions that help to obtain these results involve the estimation of different other variants of model (2) that include each component of "PCI" (introduced once in the model) and its interaction with the dummy "LDC".

Finally, we assess how the overall productive capacities and the structural economic vulnerability jointly influences economic growth volatility. To that effect, we estimate a last specification of model (2), that is, model (2) that includes the interaction between "PCI" and "EVI" (yet taking into account outliers, as mentioned above). The results of this estimation are provided in Table 8.

\section{Interpretation of empirical results}

This section discusses the empirical outcomes stemming from the estimations of model (1) and different other variants of this model (see sub-section 7.1) and the empirical outcomes stemming from the estimations of model (2) and different other variants of this model (see subsection 7.2).

\subsection{Analysis of results arising from the estimation of model (1) and its variants}

Estimates reported in column [1] of Table 1 (i.e., those based on the FE estimator) show a negative and significant effect of productive capacities on economic growth. In contrast, structural economic vulnerability does not influence economic growth at the conventional significance levels. The outcomes of column [2] (i.e., based on the FGLS estimator) suggest not only a positive and significant effect (at the $5 \%$ level) of productive capacities on economic growth, but also the existence of a non-linear relationship between structural economic vulnerability and economic growth. As observed in Figure 5, this non-linear relationship takes the form of an inverted U-

17 This dummy is related to outliers observed in the graphs of Figure 6 concerning the correlation pattern between the volatility of economic growth rate, productive capacities and structural economic vulnerability. The dummy takes the value 1 for outlier-countries and 0 , otherwise. It is important to underline that the outliers identified for the graphs that relate "GRVOL" with "PCI" on the one hand, and "GRVOL" with "EVI", on the other hand, are identical. 
curve, as the coefficient of "EVI" is positive and significant at the $1 \%$ level, while that of the squared term of "EVI" is also significant at the $1 \%$ level, but holds a negative sign.

\section{[Insert Table 1, here]}

Furthermore, the coefficient of the one-period lag of the economic growth variable is not significant at the conventional significance levels in column [1] of Table 1, whereas it is positive and significant at the $1 \%$ level in column [2] of the same Table. The comparison of these estimates in columns [1] and [2] with those based on FGLS approach that the ones based on the FGLS estimator are more in line with our theoretical expectation than those based on the FE estimator. The differences in results obtained using these two estimators can be explained by the fact the between-country variations in the indicators PCI and EVI dominate the within country variations. This means that the contribution of the overall productive capacities and structural economic vulnerability to economic growth is largely explained by the between-country variations rather than only within-country variations.

Results of control variables, in particular in column [2] of Table 1 show that higher development aid flows are positively and significantly associated with economic growth. Unexpectedly, terms of trade improvements reduce economic growth, and higher inflation enhances economic growth. The other regressors are not significantly related to economic growth. As noted above, these outcomes are likely biased, and an estimator such as the two-step system GMM approach can be more appropriate for handling the endogeneity concerns highlighted above.

Turning to results presented in Tables 2 to 4, we find that all the conditions for the validity of the two-step system GMM estimator are met satisfactorily. First, the one-period lag of the economic growth rate variable is always positive and significant at the 1\% level across all columns of these three Tables. These outcomes indicate the presence of inertia in economic growth in developing countries, and hence confirm the findings of many previous empirical works on the determinants of economic growth. We also obtain across all columns of Tables 2 to 4 , that the pvalues of the $\mathrm{AR}(1)$ test are lower than the $1 \%$ level of statistical significance, and the p-values of the $\operatorname{AR}(2)$ test are higher than the $10 \%$ level of statistical significance. Additionally, the p-values of the OID test are higher than 0.10 (i.e, the 10\% level of statistical significance) in all columns of Table 2.

\section{[Insert Table 2, here]}

With regard to estimates, we find in column [1] of Table 2 that both productive capacities and structural economic vulnerability influence positively and significantly (at the 1\% level) economic growth in developing countries. The surprising positive effect of EVI on economic growth certainly hides the existence of a non-linear relationship between structural economic vulnerability and economic growth. It can be noted from column [2] of Table 2 that the coefficient of "EVI" is positive and significant at the $1 \%$ level, while the coefficient of the squared term of "EVI" is negative and significant at the $1 \%$ level. This, therefore, suggests that there is genuinely a non-linear relationship between structural economic vulnerability and economic growth, in the form of an inverted U-curve, as observed in Figure 5. In the meantime, the coefficient of the variable "PCI" remains statistically significant in column [2] of Table 2, but is now almost the double of the coefficient of "PCI" obtained in column [1] of the same Table. This certainly highlights the need for introducing the squared term of "EVI" in the model specification; otherwise, the model would suffer from an omitted variable problem. 
However, these outcomes may be biased to the presence of outliers. Results in column [3] of Table 2, which take into account outliers, show coefficients of "PCI" and "EVI" (and its squared term) that hold the same sign as those in column [2] of Table 2, but are slightly higher than those in column [2] of Table 2. We, therefore, definitely rely on the results in column [3] of Table 2. In terms of the magnitude of the effects of the overall productive capacities, we obtain that a 1-point increase in the index of overall productive capacities generates a 0.32 -point increase in economic growth rate. In a more concrete term, an increase in the index of the overall productive capacities by a one standard deviation (i.e., by 5.161 - see Appendix 2a) leads to an increase in economic growth rate by 1.65 point $(=5.161 * 0.32)$.

\section{[Insert Figure 7, here]}

As for the effect of structural economic vulnerability on economic growth, we present in Figure 7, at the 95 per cent confidence intervals, the evolution of the marginal impact of structural economic vulnerability on economic growth for varying levels of structural economic vulnerability. The statistically significant marginal impacts at the 95 per cent confidence intervals are those determined by the upper and lower bounds of the confidence interval that are either above or below the zero line. This Figure shows that the marginal impact of structural economic vulnerability on economic growth can take positive and negative values, but decreases as the level of structural economic vulnerability rises. However, it is not always statistically significant, in particular for values of EVI comprised between 47.11 and 53.13 (these values have been obtained from the Stata software when constructing Figure 6 - they have been here multiplied by 100 as the EVI indicator in model (1) was divided by 100 before running regressions). Hence, for countries that face a level of EVI lower than 47.11, structural economic vulnerability exerts a positive and significant effect on economic growth, but the magnitude of this positive effect decreases as the level of EVI rises. In other words, the lower the level of EVI, the higher is the magnitude of the positive effect of structural economic vulnerability on economic growth. In contrast, for values of EVI higher than 53.13, structural economic vulnerability influences negatively and significantly economic growth, with the magnitude of this negative effect rising as the level of structural economic vulnerability increases. Overall, structural economic vulnerability leads to lower economic growth for high levels of EVI, notably for values of EVI exceeding 53.13 (noting that values of "EVI" in the full sample range between 9.8 and 70 - see Appendix 2a). We note that in the full sample and the last sub-period (i.e., 2015-2018), four countries appear to have faced a level of structural economic vulnerability higher than 53.13. These countries include (with the value of EVI in brackets): Chad (54.8), Gambia (70), Marshall Islands (65.7) and Tonga (57.8). Two of these are LDCs (Chad and Gambia) and the two others are NonLDCs.

Estimates concerning control variables in column [3] of Table 2 are consistent with some theoretical expectations. Economic growth is positively and significantly (at the 1\% level) driven by lower government consumption, higher development aid inflows, greater trade openness, lower inflation rates, and improvements in terms of trade. Financial openness affects negatively economic growth, but only at the $10 \%$ level.

Finally, results in column [4] of Table 2 allow examining the effect of the overall productive capacities on economic growth in LDCs and NonLDCs. It appears from this Table that the interaction term of the variable ["PCI*LDC"], and the coefficient of "PCI" are both positive and significant at the $1 \%$ level. These outcomes suggest that LDCs benefit much more (in terms of economic growth) from productive capacities than do NonLDCs. Additionally, the net effect of 
the overall productive capacities on economic growth in LDCs and NonLDCs amount respectively to $0.7(=0.279+0.424)$ and 0.424 . Thus, a rise in the index of the overall productive capacities by a 1-point is associated with an increase in economic growth rate by 0.7-point in LDCs, and by 0.42-point in NonLDCs. At this stage of the analysis, it is worth pointing out that estimates related to control variables in column [4] of Table 2 align with those in column [3] of the same Table.

\section{[Insert Table 3, here]}

We now consider outcomes reported in Table 3. To recall, these outcomes serve to examine how the components of the overall productive capacities affect economic growth over the full sample, as well as in LDCs and NonLDCs. It is worth emphasizing, at the outset, that the nonlinear relationship in the form of an inverted U-curve between structural economic vulnerability and economic growth is confirmed in the upper and lower parts of the eight columns of this Table.

As for the effect of components of the overall productive capacities on economic growth, we observe that human capital development, the enhancement of energy infrastructure, the development of ICT, the institutional and governance quality, and greater structural change in production are positively and significantly (at the 1\% level) associated with economic growth. However, as expected a rise in natural resources endowment influences negatively and significantly (also at the 1\% level) economic growth. On another note, the development of transport infrastructure and the development of the private sector do not affect economic growth at the conventional significance levels.

We also obtain that human capital accumulation, the development of ICT, and greater structural change in production exert a higher positive and significant effect (at least at the 5\% level) on economic growth rate in LDCs than in NonLDCs. However, natural resource endowment and the development of energy infrastructure exert a lower positive effect on economic growth rate in LDCs than in NonLDCs. Institutional and governance quality and the development of the private sector influence positively and significantly (at the $1 \%$ level) - with the same magnitude - economic growth in LDCs and NonLDCs. However, the development of transport infrastructure does not affect significantly economic growth in NonLDCs, but does influence negatively and significantly (at the 1\% level) economic growth in LDCs. For LDCs, the net economic growth effects of the development of human capital, natural resources, energy infrastructure, transport infrastructure, the development of ICTs, the improvement in institutional and governance quality, the development of the private sector, and the enhancement of structural change in production are given respectively by $0.415(=0.223+0.192) ;-0.14(=0.0535-0.195)$; 0.011 (=0.348 -0.337); -0.136; 0.44 (=0.142+0.302); 0.123; 0.0421, and $0.44(=0.292+0.107)$. These outcomes suggest that in LDCs, economic growth is positively driven by human capital development, the development of infrastructure in energy, ICT development, an improvement in the quality of governance and institutions, the development of the private sector, and a greater extent of structural change in production. Higher natural resources influence negatively and significantly economic growth. The development of infrastructure transport is significantly associated with lower economic growth in LDCs. As we have mentioned in sub-section 2.1.1, this finding may be explained by the fact the favourable overall economic policy conditions might not have been in place to ensure the positive contribution of infrastructure transport to economic growth.

For NonLDCs, the net economic growth effects of human capital, natural resources, energy infrastructure, transport infrastructure, ICTs, institutional and governance quality, private sector, 
and structural change in production are given respectively by the coefficients $0.223 ; 0.0535 ; 0.348$; 0 ; $0.142 ; 0.123 ; 0.042$; and 0.292 . Hence, all components of the overall productive capacities (except for transport infrastructure) influence positively and significantly economic growth in NonLDCs. The explanation put forth above concerning the negative effect of infrastructure transport on economic growth in LDCs may apply here as well to explain the lack of significant effect of transport infrastructure on economic growth.

\section{[Insert Figure 8, here] \\ [Insert Table 4, here]}

Results in Table 4 concerning the joint effect of the overall productive capacities and structural economic vulnerability on economic growth are quite interesting. All coefficients of "PCI", "EVI" and the squared term of the latter as well as those of the interaction variables are significant at the $1 \%$ level, although they do not hold the same sign. As such, the interpretation of these outcomes is difficult. This is why we proceed with a graphical analysis. We present in Figure 8 , at the 95 per cent confidence intervals, the developments of the marginal impact of productive capacities on economic growth for varying levels of structural economic vulnerability. We note from this Figure that the marginal impact of productive capacities on economic growth is always positive and statistically significant, and increases as the value of the EVI rises. This signifies that productive capacities exert a positive and significant effect on economic growth, and the magnitude of this positive effect rises as countries experience a higher degree of structural economic vulnerability. This suggests that productive capacities help to promote economic growth in countries that experience a high level of structural economic vulnerability. The message conveyed by this Figure aligns well with that of the international institutions (e.g., UNCTAD, 2020b), whereby developing countries, in particular LDCs among them (which have both low levels of productive capacities and high levels of structural economic vulnerability), should develop their productive capacities so as to build the resilience of their economies to shocks and promote sustainable economic growth.

\subsection{Analysis of results arising from the estimation of model (2) and its variants}

The outcomes displayed in column [1] of Table 5 (i.e., those based on the FE estimator) show that at the $5 \%$ level, only the real per capita income and the terms of trade variables hold significant coefficients. Countries with a higher real per capita income tend to experience a lower degree of economic growth volatility than countries with lower real per capita income. Greater volatility of terms of trade is positively associated with economic growth volatility. The lack of significance of estimates of many variables, including those of our variables of interest (i.e., productive capacities and structural economic vulnerability) may signify that the FE estimator might not be appropriate here because it disregards the between-country variations, which is large for many variables, including our variables of interest. Outcomes displayed in column [2] of Table 5 (i.e., those based on the FGLS estimator) reveal that there is an inertia in the economic growth volatility, as the coefficient of the lagged dependent variable is positive and significant at the $1 \%$ level. Additionally, the strengthening of productive capacities is negatively and significantly (at the $1 \%$ level) associated with economic growth volatility, whereas structural economic vulnerability exerts a positive and significant effect (at the 1\% level) on economic growth volatility. In contrast with the finding based on the FE estimator for the effect of the real per capita income on economic growth volatility, we obtain for results based on the FGLS estimator that the real per capita income 
influences positively and significantly economic growth volatility. Finally, greater financial openness and the volatility of development aid help to dampen the volatility of economic growth, while trade openness, inflation volatility and terms of trade volatility exert no significant effect on the volatility of economic growth at the conventional significance levels. Once again, these outcomes are likely biased because of the endogeneity concerns raised above.

\section{[Insert Table 5, here] \\ [Insert Table 6, here]}

Results reported in Tables 6 to 8 show satisfactory outcomes concerning the conditions to be met for the consistency of the two-step system GMM estimator. There is an inertia in economic growth volatility, exemplified by the (positive) and statistical significance (at the 1\% level) coefficient of the one-period lag of the economic growth volatility variable, in all columns of Tables 5 to 8 . Incidentally, in all columns of these three Tables, the p-values of the AR(1) test are lower than the $1 \%$ level, the p-values of the $\mathrm{AR}(2)$ test are higher than the $10 \%$ level; and the pvalues of the OID test are higher than 0.10 .

Taking-up estimates in column [1] of Table 6 , we find that the development of productive capacities reduces economic growth fluctuations, as the coefficient of "PCI" is negative and significant at the $1 \%$ level. Concurrently, the coefficient of "EVI" is positive and significant at the $1 \%$ level, thereby suggesting that greater structural economic vulnerability leads to a higher volatility of economic growth. However, these outcomes do not take into account the few outliers present in Figure 6. Results arising from regressions that take into account these outliers are presented in column [2] of Table 6, and definitely represent estimates that we will interpret. It is nonetheless important to note that results concerning the effect of productive capacities and structural economic vulnerability on economic growth volatility in column [2] of Table 6 are similar to those reported in column [1] of the same Table, although with slightly different coefficients across these two columns. A 1 percentage increase in economic growth volatility is associated with a 1.22 percentage fall in the indicator of economic growth volatility. Likewise, a 1 percentage increase in the indicator of structural economic vulnerability is associated with a 0.512 percentage rise in the economic growth volatility. Estimates related to control variables show that at the 1\% level, greater openness of the capital account, a higher inflation volatility, and a rise in terms of trade volatility are associated with greater volatility of economic growth. The real per capita income also appears to be positively and significantly (at the 1\% level) associated with economic growth volatility, thereby indicating that countries enjoying a higher real per capita income face a higher level of economic growth volatility than those with a lower real per capita income. This finding is to some extent surprising given that poorest countries (that have lower real per capita incomes) are likely to experience a higher economic growth volatility than other countries. But the finding may eventually be explained by the fact that the effect of the real per capita income on economic growth volatility may depend on the degree of structural economic vulnerability. Finally, trade openness and development aid volatility exert no significant effect on economic growth volatility at the conventional significance levels.

Results in column [3] of Table 6 show negative and significant coefficients (at least at the $1 \%$ level) of the interaction variables ("[Log(PCI) $\left.{ }^{*} \mathrm{LDC} "\right)$ and ("[Log(EVI) $\left.{ }^{*} \mathrm{LDC} "\right)$. Hence, productive capacities exert a higher negative effect on economic growth volatility in LDCs than in NonLDCs, and structural economic vulnerability exerts a higher positive effect on economic growth volatility in NonLDCs than in LDCs. At the same time, the coefficient of "PCI" (in Logs) 
is negative and significant at the 5\% level, and that of "EVI" (in Logs) is positive and significant at the $1 \%$ level. Therefore, we conclude that, at least at the $5 \%$ level, the net effects of productive capacities on economic growth volatility in LDCs and NonLDCs amount respectively to -1.72 (= $-0.568-1.150)$ and -0.568 . Similarly, at least at the $5 \%$ level, the net effects of productive capacities on economic growth volatility in LDCs and NonLDCs amount respectively to +0.011 ( $=0.668$ 0.657 ) and 0.668. These signify that for both LDCs and NonLDCs, greater productive capacities lead to lower economic growth volatility, although with a higher negative effect for LDCs than for NonLDCs. Likewise, structural economic vulnerability exerts a positive effect on economic growth volatility for both LDCs and NonLDCs, but the effect is higher for NonLDCs than for LDCs. This surprising finding may be explained by the fact LDCs may have received much international support to cushion the adverse effects of an increase in their structural economic vulnerability than do NonLDCs.

\section{[Insert Table 7, here]}

Turning to results in Table 7, we find in both the upper and lower parts of all columns of the Table that, with few exceptions, structural economic vulnerability enhances economic growth volatility. With respect to the effect of the components of the overall productive capacities on economic volatility (see the upper part of Table 7), we obtain that at least at the $5 \%$ level, human capital development, the building-up of energy infrastructure, the strengthening of the institutions and governance, the development of the private sector, and the promotion of structural change in production are all significantly associated with lower economic growth volatility. However, while natural resources exert no significant effect on economic growth volatility at the conventional significance levels, the development of transport infrastructure influences positively and significantly economic growth volatility. In light of the discussion under sub-section 3.1.1, we can explain this result by the fact that the development of transport infrastructure has certainly not been accompanied by the promotion of export product diversification or export sophistication, but rather by export product concentration, which has led to greater economic growth volatility.

As for the lower part of Table 7, we find that at the 5\% level, LDCs experience a higher (significant) positive effect of human capital accumulation and the development of energy infrastructure on the economic growth volatility than NonLDCs do. At the same time, the institutional and governance quality, the development of the private sector and the promotion of structural change in production exert a higher dampening effect on economic growth volatility in LDCs than in NonLDCs. At the 5\% level, there is no significant effect of the development of ICTs on economic growth volatility in both LDCs and NonLDCs alike. However, we obtain here that the effects of natural resources and transport infrastructure on economic growth volatility are positive and significant at the $1 \%$ level in both LDCs and NonLDCs, with the magnitude of these effects being respectively 1.15 and 0.413 .

For LDCs, at the 5\% level, the net economic growth volatility effects of human capital, energy infrastructure, institutional and governance quality, private sector, and structural change in production are given respectively by $-0.267(=-0.679+0.412) ;-0.12(=-1.643+1.520) ;-1.01(=$ $-0.365-0.645) ;-1.744$; and $-0.63=(0.551-1.180)$. It, therefore, follows that all these factors contribute to reducing economic growth volatility in LDCs, with the highest reducing economic growth volatility effect being attributed to the development of the private sector.

For NonLDCs, at the 5\% level, the net economic growth volatility effects of human capital, energy infrastructure, the institutional and governance quality, the private sector, and structural 
change in production are given respectively by $-0.679 ;-1.643 ;-0.365 ; 0$; and +0.551 . We infer from these outcomes that human capital development, the build-up of energy infrastructure and the improvement of institutional and governance quality are associated with lower economic growth volatility in NonLDCs, with the development of energy infrastructure generating the highest magnitude of the negative effect on economic growth volatility. The private sector development exerts no significant effect on economic growth volatility in NonLDCs. However, a greater extent of structural change is associated with a rise in economic growth volatility. This particular outcome may signify that in contrast with LDCs that are dependent on the production of low-value added products and, therefore, need to diversify their production away from the primary sector in order to reduce the volatility of economic growth, in NonLDCs, it is rather a greater specialization of production (possibly on products with relatively high value-added) in few sectors of the economy that is associated with the dampening of economic growth volatility.

\section{[Insert Table 8 , here]}

We now examine results reported in Table 8 . To recall, the main objective here is to evaluate the joint effect of the overall productive capacities and structural economic vulnerability on economic growth volatility. Thus, our key variables of interest are the interaction variable ("[Log(PCI) $\left.]^{*}[\log (\mathrm{EVI})]^{\prime}\right)$ and the variable "Log(PCI)". It appears that the coefficient of the former is negative and significant at the $1 \%$ level, and the latter holds a coefficient that is positive and significant at the $5 \%$ level. Therefore, we conclude that the total effect of productive capacities on economic growth volatility changes sign (and in particular becomes negative) when the level of structural economic vulnerability exceeds the value 7.7 (= exponential $(2.873 / 1.411)$ ). Values of the EVI indicator range between 9.8 and 70 . As the value of the turning point of EVI is lower than the minimum value of EVI in the full sample, we conclude that on average over the full sample, the overall productive capacities always exert a negative effect on economic growth volatility as the level of structural economic vulnerability increases. Furthermore, the magnitude of this negative effect increases as the level of structural economic vulnerability rises. We illustrate in Figure 9, at the 95 per cent confidence intervals, the evolution of the marginal impact of the overall productive capacities on economic growth volatility for varying levels of structural economic vulnerability. It appears that this marginal impact is always takes negative, and additionally declines as the degree of structural economic vulnerability moves upward. However, it is not statistically significant for levels of structural economic vulnerability lower than 14 (this value is obtained from the Stata software when constructing Figure 9). Thus, for countries with a level of structural economic vulnerability lower than 14, productive capacities do not influence significantly economic growth volatility. However, countries that face a higher degree of structural economic vulnerability experience a negative and significant effect of productive capacities on economic growth volatility, and the magnitude of this negative effect increases as the degree of structural economic vulnerability rises.

\section{[Insert Figure 9, here]}

Overall, the strengthening of productive capacities contributes to reducing economic growth volatility in countries that experience an increasing level of structural economic vulnerability, and the higher the level of structural economic vulnerability, the greater is the magnitude of the mitigating economic growth volatility effect of productive capacities. Thus, if the development of productive capacities were to help reduce structural economic vulnerability and enhance economic resilience, it could be argued that productive capacities would contribute to lowering economic 
growth volatility by reducing structural economic vulnerability. Once again, this finding aligns with the recommendation by international institutions, including for example, the United Nations and the WTO that developing productive capacities would help developing countries and the LDCs to strengthen the resilience of their economies to shocks, and hence reduce output volatility.

\section{Conclusion}

Over the past two decades, developing countries faced multiple external shocks (e.g., the 2008 financial crisis and the COVID-19 pandemic) and environmental shocks that have been heightening their structural economic vulnerabilities, and further exposing them to future shocks. International institutions, such as the United Nations and the WTO have usually emphasized the criticality for these countries to strengthen their productive capacities in order to build their economic resilience to shocks and engage their economies on a sustainable development path.

The present paper has investigated the effect of both productive capacities and structural economic vulnerability on economic growth and economic growth volatility. Furthermore, it has examined how both factors interact in influencing economic growth and economic growth volatility in developing countries.

The empirical results indicate that productive capacities and structural economic vulnerability affect economic growth and economic growth volatility in opposite directions. While productive capacities improve economic growth and reduce economic growth volatility, structural economic vulnerability reduces economic growth (especially once it exceeds a certain level) and enhances economic growth volatility. Interestingly, productive capacities improve economic growth and reduce economic growth volatility in countries that face an increasing degree of structural economic vulnerability.

These findings support the recommendation by international institutions and researchers that by strengthening their productive capacities, developing countries and LDCs would be able to develop the resilience of their economies to future shocks, while concurrently promoting a sustainable economic development. These findings call on the international community to better help developing countries to strengthen their productive capacities. The international community's support can take several forms, such as the provision of development aid (given the limited financial resources in developing countries, and particularly LDCs), the facilitation of migration ${ }^{18}$ from developing countries to the extent possible, and the strengthening of international cooperation to address the challenges of the $21^{\text {st }}$ century in areas such as the digital economy, the climate change, terrorism attacks, and health pandemics.

\section{References}

18 While migration from developing counties may be associated with brain drain and adversely affect the development prospects in these countries (unless there is a return of many migrants to their home countries after some years in their host countries) (see Dustmann et al., 2011), the remittances sent by migrants to their home countries can contribute to improving economic growth (e.g., Bahadir et al., 2018; Cazachevici et al., 2020; Destrée et al., 2021), promoting economic development (e.g., Piteli et al., 2019), reducing the instability of households consumption (e.g., Combes and Ebeke, 2011) and contribute to dampening output volatility (e.g., Bugamelli and Paternò, 2011). 
Abeliansky, A.L., Barbero, J., and Rodriguez-Crespo, E. (2021). ICTs quality and quantity and the margins of trade. Telecommunications Policy, 45(1), 102056.

Acemoglu, D., and Guerrieri, V. (2008). Capital Deepening and Non-Balanced Economic Growth. Journal of Political Economy, 116, 467-498.

Acemoglu, D., and Johnson, S. (2005). Unbundling institutions. Journal of Political Economy, 113(5), 949-995.

Acemoglu, D., and Robinson, J. (2010). The role of institutions in growth and development. Review of Economics and Institutions, 1(2), 1-33.

Acemoglu, D., Johnson, S., Robinson, J., and Taicharoen, Y. (2003). Institutional causes, macroeconomic symptoms: volatility, crises and growth. Journal of Monetary Economics, 50(1), 49-123.

Acevedo, S., Mrkaic, M., Novta, N., Pugacheva, E., and Topalova, P. (2020). The Effects of Weather Shocks on Economic Activity: What are the Channels of Impact? Journal of Macroeconomics, 65, 103207.

Aghion, P., Howitt, P. (1998). Endogenous Growth Theory. MIT Press, Cambridge MA.

Agosin, R., Alvarez, R., and Bravo-Ortega, C. (2012). Determinants of Export Diversification around the World: 1962-2000. The World Economy, 35(3), 295-315.

Aguiar, M., and Gopinath, G. (2007). Emerging Markets Business Cycles: The Cycle is the Trend. Journal of Political Economy, 115(1), 11-69.

Ahsan, H., and Haque, E. (2017). Threshold effects of human capital: Schooling and economic growth. Economics Letters, 156, 48-52.

Alba, J.D., Su, Z., Chia, W-M. (2011). Foreign output shocks, monetary rules and macroeconomic volatilities in small open economies. International Review of Economics \& Finance, 20(1), 71-81.

Alessandria, G., Choi, H., and Ruhl, K.J. (2021). Trade adjustment dynamics and the welfare gains from trade. Journal of International Economics, 131, 103458

Almansour, A., Aslam, A., Bluedorn, J., and Duttagupta, R. (2015). How vulnerable are emerging markets to external shocks? Journal of Policy Modeling, 37, 460-483.

Almodóvar, M. (2018). Tipo de emprendimiento y fase de desarrollo como factoresclave para el resultado de la actividad emprendedora. Cuadernos de RelacionesLaborales, 36, 225-244.

Almodóvar-González, M., Fernández-Portillo, A., and Díaz-Casero, J.C. (2020). Entrepreneurial activity and economic growth. A multi-country analysis. European Research on Management and Business Economics, 26(1), 9-17.

Almodovar-Gonzalez, M., Sanchez-Escobedo, M. C., and Fernandez-Portillo, A. (2019). Linking demographics, entrepreneurial activity, and economic growth. Revista ESPACIOS, 40(28), 1-24. 
Alouini, O., and Hubert, P. (2019). Country size, economic performance and volatility. Revue de l'OFCE, 2019/4 (164), 139-163.

Andersson, M., and Johansson, S. (2010). Human capital and the structure of regional export flows. Technology in Society, 32(3), 230-240.

Andreoni, A. (2012). Productive Capabilities Indicators for Industrial Policy Design. Development policy, statistics and research branch, Working paper 17/2011. United Nations Industrial Development Organization, Vienna.

Andrews, D., and Rees, D. (2009). Macroeconomic Volatility and Terms of Trade Shocks (Working Paper No. 2009-05). Reserve Bank of Australia, Sydney, New South Wales.

Antonakakis, N., and Badinger, H. (2016). Economic growth, volatility, and cross-country spillovers: New evidence for the G7 countries. Economic Modelling, 52 (Part B), 352-365.

Arellano, C., Bulír, A., Lane, T., and Lipschitz, L. (2009). The Dynamic Implications of Foreign Aid and its Variability. Journal of Development Economics, 88, 87-102.

Arellano, M., and O. Bover, (1995). Another Look at the Instrumental Variable Estimation of Error-Components Models, Journal of Econometrics, 68(1), 29-51.

Aron, J. (2000). Growth and institutions: A review of the evidence. The World Bank Research Observer, 15(1), 99-135.

Arrow. K. J. (1962). The Economic Implications of Learning by Doing. The Review of Economic Studies 29: 155-123.

Arteta, C., Eichengreen, B., and Wyplosz, C. (2001). When Does Capital Account Liberalization Help More. NBER Working Papers 8414, National Bureau of Economic Research, USA.

Asfaw, A., Rajabrata, M., Banerjee, and Cavoli, T. (2020). Foreign aid, institutional quality and economic growth: Evidence from the developing world. Economic Modelling, 89, 444-463.

Atolia, M., Loungani, P., Marquis, M., and Papageorgiou, C. (2018). Rethinking Development Policy: Deindustrialization, Servicification and Structural Transformation. International Monetary Fund (IMF), WP/18/223, Washington, D.C.

Audretsch, D. B. (2009). The entrepreneurial society. Journal of Technology Transfer, 34, 245254.

Auty, R.M. (2001). Introduction and overview. In: Auty, R.M. (Ed.), Resource Abundance and Economic Development. OUP, Wider Studies in Development Economics. Oxford University Press.

Azariadis, C., and Drazen, A. (1990). Threshold externalities in economic development. Quarterly Journal of Economics, 105(2), 501-526.

Azomahou, T.T., Ndung'u, N., and Ouédraogo, M. (2021). Coping with a dual shock: The economic effects of COVID-19 and oil price crises on African economies. Resources Policy, 72, 102093. 
Bacache, M., Bourreau, M., and Gaudin, G. (2013). Dynamic entry and investment in new infrastructures: Empirical evidence from the fixed broadband industry. Review of Industrial Organization, 43, 1-31.

Bacha, E. L. (1986). External shocks and growth prospects: The case of Brazil, 1973-1989. World Development, 14(8), 919-936.

Bahadir, B., Chatterjee, S., and Lebesmuehlbacher, T. (2018). The macroeconomic consequences of remittances. Journal of International Economics, 111, 214-232.

Balavac, M., and Pugh, G. (2016). The link between trade openness, export diversification, institutions and output volatility in transition countries. Economic Systems, 40(2), 273-287.

Barro, R. J. (1991). Economic growth in a cross section of countries. Quarterly Journal of Economics, 106(2), 407-443.

Barro, R. J., and Sala-i-Martin, X. (1997). Technological diffusion, convergence, and growth. Journal of Economic Growth, 2(1), 1-26.

Barrot, L.D., Calderón, C., and Servén, L. (2018). Openness, specialization, and the external vulnerability of developing countries. Journal of Development Economics, 134, 310-328.

Barua, A., Whinston, A. B., and Yin, F. (2000). Value and productivity in the Internet economy. IEEE Computer, 33(5), 102-105.

Bayraktar, N. (2019). Effectiveness of public investment on growth in Sub-Saharan Africa. Eurasian Economic Review, 9, 421-457.

Becker, G. S. (1964). Human capital. New York, USA: NBER.

Bekaert, G., Harvey, C.R. and Lundblad, C. (2006). Growth Volatility and Financial Liberalization. Journal of International Money and Finance, 25(3), 370-403.

Benhabib, J., and Spiegel, M. (1994). The role of human capital in economic development: Evidence from aggregate cross-country data. Journal of Monetary Economics, 34(2), 143-174.

Benos, N., and Zotou, S. (2014). Education and Economic Growth: A Meta-Regression Analysis. World Development, 64, 669-689.

Berg, A., Papageorgiou, C., Pattillo, C., Schindler, M., Spatafora, N., and Weisfeld, H. (2011). Global Shocks and their Impact on Low-Income Countries: Lessons from the Global Financial Crisis. Working Paper WP/11/27, International Monetary Fund (IMF), Washington, D.C.

Beverelli, C., Neumueller, S., and The, R. (2015). Export diversification effects of the WTO trade facilitation agreement. World Development,76, 293-310.

Bils, M., Klenow, P. J. (2000). Does schooling cause growth? American Economic Review, 90(5), pp. 1160-1183. 
Blecker, R.A. (2009). External Shocks, Structural Change, and Economic Growth in Mexico, 19792007. World Development, 37(7), 1274-1284.

Blundell, R., and Bond, S. (1998). Initial Conditions and Moment Restrictions in Dynamic Panel Data Models. Journal of Econometrics, 87(1), 115-143.

Bojnec, S., and Ferto, I. (2012). Broadband availability and economic growth. Industrial Management and Data Systems, 112(9), 1292-1306.

Boone, P. (1996). Politics and the effectiveness of foreign aid. European Economic Review, 40(2), 289-329.

Bosworth, B. P., and Collins, S. M. (2003). The empirics of growth: An update. Brookings Papers on Economic Activity, 34(2), 113-206.

Brunetti, A., Kisunko, G., and Weder, B. (1998). Credibility of Rules and Economic Growth: Evidence from a Worldwide Survey of the Private Sector. The World Bank Economic Review, 12(3), 353-384.

Brunnschweiler, C.N., and Bulte, E.H. (2008). The resource curse revisited and revised: a tale of paradoxes and red herrings. Journal of Environmental Economics and Management, 55, 248-264.

Bugamelli, M., and Paternò, F. (2011). Output Growth Volatility and Remittances. Economica, 78(311), 480-500.

Bulte, E. H., Damania, R., and Deacon, R. (2005). Resource Intensity, Institutions, and Development. World Development, 33(7), 1029-1044.

Burnside, C., and Dollar, D. (2000). Aid, policies and growth. American Economic Review, 90(4), 847-869.

Bustos, S., Gomez, C., Hausmann, R., Hidalgo, C.A. (2012). The dynamics of nestedness predicts the evolution of industrial ecosystems. PloS ONE, 7(11), e49393.

Calderón, C., and Servén, L. (2004). Trend in infrastructure in Latin America 1980-2001 (Policy research working paper series 4712). World Bank, Washington, DC.

Calderón, C., Moral-Benito, E., \& Servén, L. (2015). Is infrastructure capital productive? A dynamic heterogeneous approach. Journal of Applied Econometrics, 30(2), 177-198.

Calderon, C.A., Loayza, N., and Klaus, S-H. (2005). Does Openness Imply Greater Exposure? (October 2005). World Bank Policy Research Working Paper No. 3733. World Bank, Washington, D.C.

Canh, N. P., and Thanh, S.D. (2020). The Dynamics of Export Diversification, Economic Complexity and Economic Growth Cycles: Global Evidence. Foreign Trade Review, https://doi.org/10.1177/0015732520970441

Cariolle, J., Goujon, M., and Guillaumont, P. (2016). Has Structural Economic Vulnerability Decreased in Least Developed Countries? Lessons Drawn from Retrospective Indices. The Journal of Development Studies, 52(5), 591-606. 
Cavalcanti, D. V., V. Tiago, K. Mohaddes, \& M. Raissi. (2015). Commodity price volatility and the sources of growth. Journal of Applied Econometrics, 30(6), 857-873.

Cazachevici, A., Havranek, T., and Horvath, R. (2020). Remittances and economic growth: A metaanalysis. World Development, 134, 105021.

Chakamera, C., and Alagidede, P. (2018). The nexus between infrastructure (quantity and quality) and economic growth in Sub Saharan Africa. International Review of Applied Economics, 32(5), 641-672.

Chang, R., Kaltani, L., and Loayza, N. V. (2009). Openness can be good for growth: The role of policy complementarities. Journal of Development Economics, 90, 33-49.

Chatterjee, S., and Turnovsky, S.J. (2007). Foreign aid and economic growth: the role of flexible labour supply. Journal of Development Economics, 84, 507-533.

Chauvet, L., and Ehrhart, H. (2018). Aid and growth: evidence from firm-level data. Journal of Development Economics, 135, 461-477.

Chen, W.-C. (2013). The Extensive and Intensive Margins of Exports: The Role of Innovation. The World Economy, 36(5), 607-635.

Chinn, M. D. and Ito, H. (2006). What Matters for Financial Development? Capital Controls, Institutions, and Interactions. Journal of Development Economics, 81(1), 163-192.

Choi, K-H., and Shin, S. (2017). Population aging, economic growth, and the social transmission of human capital: An analysis with an overlapping generations model.

Collier, P., and Dollar, D. (2002). Aid allocation and poverty reduction. European Economic Review, 46(8), 1475-1500.

Combes, J-L., and Ebeke, C. (2011). Remittances and Household Consumption Instability in Developing Countries. World Development, 39(7), 1076-1089.

Cordina, G. (2004). Economic Vulnerability and Economic Growth: Some Results from a NeoClassical Growth Modelling Approach. Journal of Economic Development, 29(2), 21-39.

Cornia, G.A., and Scognamillo, A. (2016). Clusters of Least-developed Countries, their evolution between 1993 and 2013, and policies to expand their productive capacity. CDP Background Paper No. 33, ST/ESA/2016/CDP/33. United Nations Department of Economics and Social Affairs, New York, N.Y., USA.

Cronin, F. J., Colleran, E. K., Herbert, P. L., and Lewitzky, S. (1993). Telecommunication infrastructure investment and economic development. Telecommunication Policy, 17(6), 415-430.

Czernich, N., Falck, O., Kretschmer, T., \& Woessmann, L. (2011). Broadband infrastructure and economic growth. The Economic Journal, 121(552), 505-532. 
Dabla-Norris, E., and Gündüz, Y. B. (2014). Exogenous Shocks and Growth Crises in LowIncome Countries: A Vulnerability Index. World Development, 59, 360-378.

Dabla-Norris, E., Minoiu, C., and Zanna, L-F. (2015). Business Cycle Fluctuations, Large Macroeconomic Shocks, and Development Aid. World Development, 69, 44-61.

Dalgaard, C.-J., Hansen, H., and Tarp, F. (2004). On the empirics of foreign aid and growth. Economic Journal, 114(496), 191-216.

Démurger, S. (2001). Infrastructure development and economic growth: an explanation for regional disparities in China?. Journal of Comparative economics, 29(1), 95-117.

Dennis, A., and Shepherd, B. (2011). Trade Facilitation and Export Diversification. The World Economy, 34(1), 101-122.

Desai, S., Acs, Z. J., and Weitzel, U. (2013). A model of destructive entrepreneurship: Insight for conflict and post-conflict recovery. The Journal of Conflict Resolution, 57, 20-40.

Destrée, N., Gente, K., and Nourry, C. (2021). Migration, remittances and accumulation of human capital with endogenous debt constraints. Mathematical Social Sciences, Available online 8 April 2021, https://doi.org/10.1016/i.mathsocsci.2021.03.008

Ding, N., and Field, B.C. (2005). Natural resource abundance and economic growth. Land Economics, 81,496-502.

Djankov, S., McLiesh, C., and Ramalho, R. M. (2006). Regulation and growth. Economics Letters, 92(3), 395-401.

Djimeu, E.W., and Omgba, L.D. (2019). Oil windfalls and export diversification in oil-producing countries: Evidence from oil booms. Energy Economics, 78, 494-507.

Dollar, D., and Kraay, A. (2004). Trade. Growth and Poverty. Economic Journal, 114, 22-49.

Dufrenot, G., Mignon, V., and Tsangarides, C. (2010). The trade growth nexus in the developing countries: A quantile regression approach. Review of World Economics, 146, 731-761.

Durlauf, S. N., and Johnson, P. A. (1995). Multiple regimes and cross-country growth behavior. Journal of Applied Econometrics, 10(4), 365-384.

Dustmann, C., Fadlon, I., and Weiss, Y. (2011). Return migration, human capital accumulation and the brain drain. Journal of Development Economics, 95(1), 58-67.

Dzhumashev, R., and Hailemariam, A. (2021). Foreign aid and the quality of economic institutions. European Journal of Political Economy, 102001, In Press, Corrected Proof, https://doi.org/10.1016/i.ejpoleco.2021.102001

Easterly, W. (2005). What did structural adjustment adjust? The association of policies and growth with repeated IMF and World Bank adjustment loans. Journal of Development Economics, 76(1), $1-22$. 
Easterly, W., and Kraay, A. (2000). Small States, Small Problems? Income, Growth, and Volatility in Small States. World Development, 28(11), 2013-2027.

Easterly, W., Islam, R., and Stiglitz, J. (2000). Explaining Growth Volatility. World Bank Working Paper 04/13, Washington, D.C.

Ebeke, C., and Ehrhart, H. (2012). Tax Revenue Instability in Sub-Saharan Africa: Consequences and Remedies. Journal of African Economies, 21(1), 1-27.

Economides, G., Kalyvitis, S., and Philippopoulos, A. (2008). Does foreign aid distort incentives and hurt growth? Theory and evidence from 75 aid-recipient countries. Public Choice, 134, 463488.

Edison, H.J., Klein, M.W., Ricci, L.A., and Sløk, T. (2004). Capital Account Liberalization and Economic Performance: Survey and Synthesis. IMF Staff Papers, 51(2), 220-256.

Erumban, A. A., Das, D.K., Aggarwal, S., and Das, P.C. (2019). Structural change and economic growth in India. Structural Change and Economic Dynamics, 51, 186-202.

Essers, D. (2013). Developing country vulnerability in light of the global financial crisis: Shock therapy? Review of Development Finance, 3(2), 61-83.

Fadahunsi, A., and Rosa, P. (2002). Entrepreneurship and illegality: Insights from the Nigerian cross-border trade. Journal of Business Venturing, 17, 397-429.

Fan, S., and Zhang, X. (2004). Infrastructure and regional economic development in rural China. China economic review, 15(2), 203-214.

Feenstra, R. C., and Ma, H. (2014). Trade facilitation and the extensive margin of exports. Japanese Economic Review, 65, 158-177.

Feindouno, S., and Goujon, M. (2016). The retrospective economic vulnerability index, 2015 update. Working paper n¹47, Fondation pour les Etudes et Recherches sur le Developpement InternationaL (FERDI), Clermont-Ferrand, France.

Freire, C. (2011). Productive Capacities in Asia and the Pacific. MPDD Working Papers, WP/11/17. United Nations Economic and Social Commission for Asia and the Pacific, Bangkok, Thailand.

Fomby, T., and Ikeda, Y., and Loayza, N.V. (2013). The Growth Aftermath of Natural Disasters. Journal of Applied Econometrics, 28(3), 412-434.

Fonseca, T., de Faria, P., and Lima, F. (2019). Human capital and innovation: the importance of the optimal organizational task structure. Research Policy, 48(3), 616-627.

Frankel, J. A., and Romer, D. (1999). Does trade cause growth? American Economic Review, 89, 379-399.

Freire-Serén, M. J., and i Martí, J. P. (2013). Tax avoidance, human capital accumulation and economic growth. Economic Modelling, 30, 22-29. 
Furceri, D., and Karras, G. (2007). Country size and business cycle volatility: Scale really matters.” Journal of the Japanese and International Economies, 21(4), 424-434.

García-Rodríguez, F., Gil-Soto, E., Ruiz-Rosa, I., and Gutiérrez-Taño, D. (2017). Entrepreneurial potential in less innovative regions: the impact of social and cultural environment. European Journal of Management and Business Economics,26(No. 2), 163-179.

Gavin, M., and Hausmann, R. (1998). Macroeconomic Volatility and Economic Development. In: Borner S., Paldam M. (eds) The Political Dimension of Economic Growth. International Economic Association Series. Palgrave Macmillan, London.

Ghosh, S. (2013). The economics and politics of output volatility: evidence from Indian states. International Review of Applied Economics, 27(1), 110-134.

Glewwe, P., Maïga, E., and Zheng, H. (2014). The Contribution of Education to Economic Growth: A Review of the Evidence, with Special Attention and an Application to Sub-Saharan Africa. World Development, 59, 379-393.

Gnangnon, S.K. (2018). Impact of multilateral trade liberalization and aid for trade for productive capacity building on export revenue instability. Economic Analysis and Policy, 58, 141-152.

Gnangnon S K (2019). Has the W'TO's Aid for Trade Initiative Delivered on Its Promise of Greater Mobilization of Development Aid in Favor of the Trade Sector in Developing Countries?. International Trade Journal, 33(6), 519-541.

Gnangnon, S. K. (2020). Effect of the Internet on Services Export Diversification. Journal of Economic Integration, 35(3), 519-558.

Gómez-Gras, J. M., Mira-Solves, I., and Martínez-Mateo, J. (2011). Determinants of entrepreneurship: An overview. International Journal of Business Environment, 3, 1-14.

González-Vala, R., and Pueyo, F. (2019). Natural resources, economic growth and geography. Economic Modelling, 83, 150-159.

Goujon, M., and Guillaumont, P. (2016). Has Structural Economic Vulnerability Decreased in Least Developed Countries? Lessons Drawn from Retrospective Indices. The Journal of Development Studies, 52(5), 591-606.

Gradstein, M., and Justman, M. (2002). Education, Social Cohesion, and Economic Growth. American Economic Review, 92(4), 1192-1204.

Greenwood, J., \& Seshadri, A. (2005). Technological progress and economic transformation. In P. Aghion, \& S. Durlauf (Eds.), Handbook of economic growth (vol. 1B, pp. 1225-1273). Amsterdam \& New York: North Holland.

Guillaumont, P. (2010) Assessing the Economic Vulnerability of Small Island Developing States and the Least Developed Countries. The Journal of Development Studies, 46(5), 828-854. 
Guillaumont, P., and Chauvet, L. (2001). Aid and performance: A reassessment. Journal of Development Studies, 37(6), 66-92.

Guillaumont, P., and Wagner, L. (2012). Aid and Growth Accelerations: Vulnerability Matters. UNU-WIDER Working Paper Series WP-2012-031, UNU World Institute for Development Economics Research (UNU-WIDER), Helsinki, Finland.

Güneri, B., and Yalta, A. Y. (2020). Does economic complexity reduce output volatility in developing countries? Bulletin of Economic Research, https://doi.org/10.1111/boer.12257

Gylfason T. (2006) Natural Resources and Economic Growth: From Dependence to Diversification. In: Broadman H.G., Paas T., Welfens P.J. (eds) Economic Liberalization and Integration Policy. Springer, Berlin, Heidelberg. https://doi.org/10.1007/3-540-31183-1_10

Haddad, M., Lim, J. J., Pancaro, C., and Saborowski, C. (2013). Trade openness reduces growth volatility when countries are well diversified. Canadian Journal of Economics, 46(2), 765-790.

Hansen, H., and Tarp, F. (2001). Aid and growth regressions. Journal of Development Economics, 64(2), 547-570.

Harb, N., and Hall, S.G. (2019). Does foreign aid play a role in the maintenance of economic growth? A non-linear analysis. The Quarterly Review of Economics and Finance, 73, 192-204.

Harchaoui, T.M. (2019). Global volatility accounting and structural transformation. Oxford Economic Papers, 1-24. doi: 10.1093/oep/gpz074

Hausmann, R., and Hidalgo, C.A. (2009). The building blocks of economic complexity. Proceedings of the National Academy of Sciences, 106 (26), 10570-10575.

Hausmann, R., and Hidalgo, C.A. (2011). The network structure of economic output. Journal of Economic Growth, 16(4), 309-342.

Haussmann, R., Hwang, J., and Rodrik, D. (2007). What you export matters. Journal of Economic Growth, 12, 1-25.

Henry, P.B. (2007). Capital Account Liberalization: Theory, Evidence, and Speculation. Journal of Economic Literature, 45(4), 887-935.

Herrendorf, B., Rogerson R., and Valentinyi, A. (2014). Growth and structural transformation. In P. Aghion, \& S. Durlauf (Eds.), Handbook of economic growth (vol. 2, pp. 855-941). Amsterdam \& New York: North Holland.

Hidalgo, C.A., Klinger, B., Barabási, A.-L., Hausmann, R. (2007). The product space conditions the development of nations. Science, 317 (5837), 482-487.

Hodler, R. (2004). Rent seeking and aid effectiveness. International Tax and Public Finance, 14 (5), 525-541.

Holt, L., and Jamison, M. (2009). Broadband and contributions to economic growth: Lessons from the US experience. Telecommunications Policy, 33, 575-581. 
Huchet-Bourdon, M., Le Mouël, C., and Vijil, M. (2018). The relationship between trade openness and economic growth: Some new insights on the openness measurement issue. The World Economy, 41(1), 59-76.

Hudson, J., and Mosley, P. (2008). The Macroeconomic Impact of Aid Volatility. Economics Letters, 99(3), 486-9.

Hynes, W., and Lammersen, F. (2017). Facilitate trade for development: Aid for trade, ADBI Working Paper, No. 670, Asian Development Bank Institute (ADBI), Tokyo.

Imbs, J. (2007). Growth and volatility. Journal of Monetary Economics, 54(7), 1848-1862.

Isham, J., Pritchett, L., Woolcock, M., and Busby, G. (2005). The Varieties of Resource Experience: Natural Resource Export Structures and the Political Economy of Economic Growth. World Bank Economic Review, 19(2), 141-74.

Iwanow, T., and Kirkpatrick, C. (2009). Trade facilitation and manufactured exports: Is Africa different?. World Development, 37, 1039-1050.

Jawaid, S.T., and Waheed, A. (2011). Effects of Terms of Trade and its Volatility on Economic Growth: A Cross Country Empirical Investigation. Transition Studies Review, 18, 217-229.

Jetter, M., and Hassan, A.R. (2015). Want export diversification? Educate the kids first. Economic Inquiry, 53(4), 1765-1782.

Jorgenson, D.W. (2001). Information Technology and the U.S. Economy. The American Economic Review, 91(1), 1-32.

Joya, O. (2015). Growth and volatility in resource-rich countries: Does diversification help? Structural Change and Economic Dynamics, 35, 38-55.

Junior, C.J.C., Garcia-Cintado, A.C., and Junior, K.M. (2021). Macroeconomic policies and the pandemic-driven recession. International Review of Economics \& Finance, 72, 438-465.

Kalkuhl, M., and Wenz, L. (2020). The impact of climate conditions on economic production. Evidence from a global panel of regions. Journal of Environmental Economics and Management, 103, 102360.

Kaneko, A. (2000). Terms of trade, economic growth, and trade patterns: a small open-economy case. Journal of International Economics, 52, 169-181.

Ke, X., Lin, J., Yifu, Fu, C., and Wang, Y. (2020). Transport Infrastructure Development and Economic Growth in China: Recent Evidence from Dynamic Panel System-GMM Analysis.

Kim, D-H., Lin, S-C., and Suen, Y-B. (2016). Trade, growth and growth volatility: New panel evidence. International Review of Economics \& Finance, 45, 384-399. 
Kim, Y., Lim, H., and Sohn, W. (2020). Which external shock matters in small open economies? Global risk aversion vs. US economic policy uncertainty. Japan and the World Economy, 54, 101011.

Klein, M. U. (2003). Ways Out of Poverty: Diffusing Best Practices and Creating Capabilities. Policy Research Working Paper 2990. Washington DC: World Bank.

Klomp, J., and Valckx, K. (2014). Natural disasters and economic growth: A meta-analysis. Global Environmental Change, 26, 183-195.

Kose, M.A., Prasad, E.S., and Terrones, M. (2003). Financial Integration and Macroeconomic Volatility. IMF Staff Papers, 50 (Special Issue), 119-42.

Koutroumpis, P. (2009). Broadband infrastructure and economic growth: A simultaneous approach. Telecommunications Policy, 33(9), 471-485.

Kose, M.A., and Riezman, R. (2001). Trade shocks and macroeconomic fluctuations in Africa. Journal of Development Economics, 65(1), 55-80.

Kpodar, K., Le Goff, M., and Singh, R.J. (2018). Financial deepening, terms of trade shocks, and growth volatility in low-income countries. Revue d'économie du développement, 26(4), 27-68.

Kramarz, F., Martin, J., and Mejean, I. (2020). Volatility in the small and in the large: The lack of diversification in international trade. Journal of International Economics, 122, Article 103276.

Krueger, A.B., and Lindahl, M. (2001). Education for Growth: why and for whom? Journal of Economic Literature, 39, 1101-1136.

Lall, S. (1992). Technological capabilities and industrialization. World Development, 20(2), 165186.

Lapatinas, A. (2019). The effect of the Internet on economic sophistication: An empirical analysis. Economics Letters 174, 35-38.

Lavopa, A., and Szirmai, A. (2018). Structural modernisation and development traps. An empirical approach. World Development, 112, 59-73.

Lee, C. G. (2010). Education and economic growth: Further empirical evidence. European Journal of Economics, Finance and Administrative Sciences, 23, 161-169.

Lenihan, H., McGuirk, H., and Murphy, K. R. (2019). Driving innovation: Public policy and human capital. Research Policy, 48(9), 103791.

Levine, R., and Renelt, D. (1992). A sensitivity analysis of cross-country growth regressions. American Economic Review, 82(4), 942-963.

Lewis, W. A. (1954). Economic development with unlimited supplies of labour. The Manchester School, 28, 139-191.

Letendre, M-A., and Obaid, S. (2020). Emerging economy business cycles: Interest rate shocks vs trend shocks. Economic Modelling, 93, 526-545. 
Li, H., and Huang, L. (2009). Health, education, and economic growth in China: Empirical findings and implications. China Economic Review, 20, 374-387.

Liñán, F. and Fernández-Serrano, J. (2014). National culture, entrepreneurship and economic development: Different patterns across the European Union. Small Business Economics, 42, 685702.

Loayza, N. V., Olaberría, E., Rigolini, J., and Christiaensen, L. (2012). Natural Disasters and Growth: Going Beyond the Averages. World Development, 40(7), 1317-1336.

Loayza, N.V., Rancière, R., Servén, L., and Ventura, J. (2007). Macroeconomic Volatility and Welfare in Developing Countries: An Introduction, The World Bank Economic Review, 21(3), 343-357.

Loc, T. D., Lanjouw, G., and Lensink, R. (2006). The Impact of Privatization on Firm Performance in a Transition Economy.' Economics of 'Transition, 14(2), 349-389.

López-Bazo, E., and Motellón, E. (2012). Human Capital and Regional Wage Gaps. Regional Studies, 46/10, 1347-1365.

Lucas, R. (1988). On the mechanics of economic development. Journal of Monetary Economics, $22,3-42$.

Maggioni, D., Lo Turco, A., and Gallegati, M. (2016). Does product complexity matter for firms' output volatility? Journal of Development Economics, 121, 94-109.

Malik, A., and Temple, J. R. W. (2009). The geography of output volatility. Journal of Development Economics, 90(2), 163-178.

Mankiw, N. G., Romer, D., and Weil, D. (1992). A contribution to the empirics of economic growth. Quarterly Journal of Economics, 107(2), 407-437.

Mariz-Perez, R.M., Teijeiro-Alvarez, M.M., and Garcì-Alvarez, M.T. (2012). The relevance of human capital as a driver for innovation. Cuadernos de Economía, 35(98), 68-76.

Marlow, M.L. (1986). Private Sector Shrinkage and the Growth of Industrialized Economies. Public Choice, 49(2), 143-154.

Massol, O., and Banal-Estañol, A. (2014). Export diversification through resource-based industrialization: The case of natural gas. European Journal of Operational Research, 237(3), 10671082.

Mavrotas, G., Murshed, S. M., and Torres, S. (2011). Natural resource dependence and economic performance in the 1970-2000 period. Review of Development Economics, 15(1), 124-138.

McConnell, M.M., and Perez-Quiros, G. (2000). Output fluctuations in the United States: what has changed since the early 1980's? American Economic Review, 90, 1464-1476.

McMahon, W. W. (2018). The total return to higher education: Is there underinvestment for economic growth and development? The Quarterly Review of Economics and Finance, 70, 90111. 
McMillan, M., and Rodrik, D., and Verduzco-Gallo, I. (2014). Globalization, Structural Change, and Productivity Growth, with an Update on Africa. World Development, 63, 11-32.

Meller, B. (2013). The two-sided effect of financial globalization on output volatility. Review of World Economics, 149, 477-504.

Minoiu, C., and Reddy, S.G. (2010). Development aid and economic growth: A positive long-run relation. The Quarterly Review of Economics and Finance, 50(1), 27-39.

Miranda-Pinto, J. (2021). Production network structure, service share, and aggregate volatility. Review of Economic Dynamics, 39, 146-173.

Montalbano, P. (2011). Trade Openness and Developing Countries' Vulnerability: Concepts, Misconceptions, and Directions for Research. World Development, 39(9), 1489-1502.

Moro, A. (2012). The Structural Transformation between Manufacturing and Services and the decline in the U.S. GDP Volatility. Review of Economic Dynamics, 15(3), 402-415.

Moro, A. (2015). Structural Change, Growth, and Volatility. American Economic Journal: Macroeconomics, 7(3), 259-294.

Museru, M., Toerien, F., and Gossel, S. (2014). The impact of aid and public investment volatility on economic growth in sub-Saharan Africa. World Development, 57, 138-147.

Nalban, V., and Smădu, A. (2021). The interaction between private sector and public sector labor markets: Evidence from Romania. Economic Modelling, 94, 804-821.

Nelson, R., and Phelps, E. (1966). Investment in humans, technological diffusion, and economic growth. American Economic Review: Papers and Proceedings, 51(2), 69-75.

Ngouana, C. A. L. (2013). Structural Transformation and the Volatility of Aggregate Output in OECD Countries. IMF Working Paper WP/13/43, International Monetary Fund, Washington, D.C.

Nickell, S. (1981). Biases in Dynamic Models with Fixed Effects. Econometrica, 49(6), 1417-1426.

Obstfeld, M. (1999). Foreign resource inflows, savings and growth. In: Schmidt-Hebbel, K., Serven, L. (Eds.), The Economics of Savings and Growth. In Cambridge University Press, Cambridge, pp. 107-146.

OECD (2007). Aid for Trade: Making It Effective. Chapter 2 of the 2006 Development Cooperation Report: 'Efforts and Policies of the Members of the Development Assistance Committee', Volume 8, No. 1.

OECD/WTO (2019), Aid for Trade at a Glance 2019: Economic Diversification and Empowerment, OECD Publishing, Paris, https://doi.org/10.1787/18ea27d8-en.

Ordeñana, X., Vera-Gilces, P., Zambrano-Vera, J. and Amaya, A. (2019). Does all entrepreneurship matter? The contribution of entrepreneurial activity to economic growth. Academia Revista Latinoamericana de Administración, 33(1), 25-48. 
Organization of Economic Cooperation and Development (OECD). (2001). The development of broadband access in OECD countries. Paris: Head of Publications Service, OECD.

Persson, M. (2013). Trade facilitation and the extensive margin. The Journal of International Trade \& Economic Development, 22, 658-693.

Pham, N-S., and Pham, T.K.C. (2020). Effects of foreign aid on the recipient country's economic growth. Journal of Mathematical Economics, 86, 52-68.

Piteli, E.E.N., Buckley, P.J., and Kafouros, M. (2019). Do remittances to emerging countries improve their economic development? Understanding the contingent role of culture. Journal of International Management, 25(4), 100675.

Pradhan, R.P., and Bagchi, T.P. (2013). Effect of transportation infrastructure on economic growth in India: The VECM approach. Research in Transportation Economics, 38(1), 139-148.

Pradhan, R.P., Mallik, G., and Bagchi, T.P. (2018). Information communication technology (ICT) infrastructure and economic growth: A causality evinced by cross-country panel data. IIMB Management Review, 30, 91-103.

Qiang, Q., and Jian, C. (2020). Natural resource endowment, institutional quality and China's regional economic growth. Resources Policy, 66, 101644.

Quinn, D.P., and Toyoda, A. M. (2008). Does Capital Account Liberalization Lead to Growth? The Review of Financial Studies, 21(3), 1403-1449.

Raddatz, C. (2007). Are external shocks responsible for the instability of output in low-income countries? Journal of Development Economics, 84(1), 155-187.

Raddatz, C. (2008). Have External Shocks Become More Important for Output Fluctuations in African Countries?”. In Africa at a Turning Point? Growth, Aid, and External Shocks (Ed.). Africa Development Essays Series. The World Bank, Washington, D.C.

Rajan, R., and Subramanian, A. (2008). Aid and growth: What does the cross-country evidence really show? Review of Economics and Statistics, 90(4), 643-665.

Ramey, V.A. (2016). Macroeconomic Shocks and Their Propagation, "In Handbook of Macroeconomics - Chapter 2, Volume 2, p 71-162.

Rampini, A., A. (2004). Entrepreneurial activity, risk, and the business cycle. Journal of Monetary Economics, 51(3), 555-573.

Rasaki, M.G., and Malikane, C. (2015). Macroeconomic shocks and fluctuations in African economies. Economic Systems, 39(4), 675-696.

Ray, D. (2010). Uneven Growth: A Framework for Research in Development Economics. Journal of Economic Perspectives, 24, 45-60. 
Regolo, J. (2013). Export diversification: How much does the choice of the trading partner matter? Journal of International Economics, 91(2), 329-342.

Rivera-Batiz, L. A., and Romer, P. M. (1991). International trade with endogenous technological change. European Economic Review, 35, 971-1001.

Rodrik, D. and Subramanian, A. (2009). Why did financial globalization disappoint? IMF staff papers, 56(1), 112-138.

Romer, P. (1986). Increasing returns and long-run growth. Journal of Political Economy, 94(5), 1002-1037.

Romer, P. M. (1989). Human capital and growth: Theory and evidence. NBER Working Paper $3173,1-51$.

Ross, M. L. (2019). What do we know about export diversification in oil-producing countries? The Extractive Industries and Society, 6(3), 792-806.

Sahay, R., Čihák, M., N’Diaye, P., Barajas, A., Bi, R., Ayala, D., Gao, Y., Kyobe, A., Nguyen, L., Saborowski, C., Svirydzenka, K., and Yousefi, S.R. (2015). Rethinking Financial Deepening: Stability and Growth in Emerging Markets. IMF Staff Discussion Note, SDN/15/08, International Monetary Fund, Washington, D.C.

Sahoo, P., and Dash, R. K. (2012). Economic growth in South Asia: Role of infrastructure. The Journal of International Trade \& Economic Development, 21(2), 217-252.

Saltarelli, F., Cimini, V., Tacchella, A., Zaccaria, A., and Cristelli, M. (2020). Is Export a Probe for Domestic Production? Frontiers in Physics, 8, 180, doi: 10.3389/fphy.2020.00180

Shiferaw, A. (2017). Productive Capacity and Economic Growth in Ethiopia. CDP Background Paper No. 34, ST/ESA/2017/CDP/34. United Nations, Department of Economics and Social Affairs, New York, N.Y., USA.

Shepherd, B. (2010). Geographical Diversification of Developing Country Exports. World Development, 38(9), 1217-1228.

Shi, Y., Guo, S., and Sun, P. (2017). The role of infrastructure in China's regional economic growth. Journal of Asian Economics, 49, 26-41.

Siddiqui, D.A., and Ahmed, Q. M. (2013). The effect of institutions on economic growth: A global analysis based on GMM dynamic panel estimation. Structural Change and Economic Dynamics, 24, 18-33.

Steer, L., and Taussig, M. (2002). A Little Engine that Could...: Domestic Private Companies and Vietnam's Pressing Need for Wage Employment. Policy Research Working Paper 2873. Washington DC: World Bank.

Su, Y., and Liu, Z. (2016). The impact of foreign direct investment and human capital on economic growth: Evidence from Chinese cities. China Economic Review, 37, 97-109. 
Sun, X., Li, H., and Ghosal, V. (2020). Firm-level human capital and innovation: Evidence from China. China Economic Review, 59, 101388

Temple, J. (2001). Growth effects of education and social capital in the OECD countries. OECD Economic Studies, 33, 57-101.

Thompson, H., and Garbacz, C. (2008). Broadband impacts on state GDP: direct and indirect impacts. Paper presented at the International Telecommunications Society 17 th Biennial Conference, Canada.

Timilsina, G., Hochman, G., and Song, Z. (2020). Infrastructure, Economic Growth, and Poverty: A Review. Policy Research Working Paper 9258. World Bank, Washington, D.C.

Ulaşan, B. (2015). Trade openness and economic growth: Panel evidence. Applied Economics Letters, 22, 163-167.

UN (2017). Expanding Productive Capacity - Lessons Learned from Graduating Least Developed Countries. Committee for Development Policy, United Nations publication, Sales No.: E.18.II.C.3, 59 pages.

UNCTAD (2018). The Least Developed Countries Report 2018: Entrepreneurship for Structural Transformation: Beyond Business as Usual. United Nations publication. Sales No. E.18.II.D.6. New York and Geneva.

UNCTAD (2006). The Least Developed Countries Report 2006: Developing Productive Capacities. United Nations publication. Sales No. E.06.II.D.9. New York and Geneva.

UNCTAD (2020a). Building and Utilizing Productive Capacities in Africa and the Least-developed Countries - A Holistic and Practical Guide. UNCTAD, Geneva, Switzerland.

UNCTAD (2020b). The Least Developed Countries Report 2020: Productive Capacities for the New Decade. United Nations publication. Sales No. E.21.II.D.2 New York and Geneva.

UNIDO (2001). Building productive capacity for poverty alleviation in Least developed countries (LDC's) - The Role of Industry. United Nations Industrial Development Organization, Vienna, 2001. https://www.unido.org/sites/default/files/2006-10/ldciii08 0.pdf

Van Gaasbeck, K. A. (2008). A rising tide: Measuring the economic effects of broadband use across California. The Social Science Journal, 45, 691-699.

Vannoorenberghe, G., Wang, Z., and Yu, Z. (2016). Volatility and diversification of exports: Firmlevel theory and evidence. European Economic Review, 89, 216-247.

Vu, K. M. (2017). Structural change and economic growth: Empirical evidence and policy insights from Asian economies. Structural Change and Economic Dynamics, 41, 64-77.

Wagner, L. (2014). Identifying thresholds in aid effectiveness. Review of World Economics, 150 (3), 619-638.

Wang, C., Lim, M. K., Zhang, X., Zhao, L., and Lee, P. T-W. (2020). Railway and road infrastructure in the Belt and Road Initiative countries: Estimating the impact of transport 
infrastructure on economic growth. Transportation Research Part A: Policy and Practice, 134, 288307.

World Bank (1994). World Development Report: Providing Infrastructure for Development; Oxford University Press: New York, NY, USA, 1994, pp. 71-199.

Yanikkaya, H. (2003). Trade openness and economic growth: a cross-country empirical investigation. Journal of Development Economics, 72(1), 57-89.

Yeyati, E. L., Panizza U, and Stein, E. (2007). The cyclical nature of North-South FDI flows. Journal of International Money and Finance, 26, 104-130.

Zallé, O. (2019). Natural resources and economic growth in Africa: The role of institutional quality and human capital. Resources Policy, 62, 616-624.

Zhang, C., and Zhuang, L. (2011). The composition of human capital and economic growth: Evidence from China using dynamic panel data analysis. China Economic Review, 22(1), 165-171. 


\section{TABLES and APPENDICES}

Table 1: Effect of productive capacities and structural economic vulnerability on economic growth_over the full sample

Estimators: FE and FGLS

\begin{tabular}{|c|c|c|}
\hline & FE & FGLS \\
\hline \multirow[t]{2}{*}{ Variables } & GROWTH & GROWTH \\
\hline & $(1)$ & $(2)$ \\
\hline \multirow[t]{2}{*}{ GROWTH $_{\mathrm{t}-1}$} & -0.0303 & $0.337 * * *$ \\
\hline & $(0.0249)$ & $(0.0218)$ \\
\hline \multirow[t]{2}{*}{$\mathrm{PCI}_{\mathrm{t}-1}$} & $-0.554 * * *$ & $0.0431^{* *}$ \\
\hline & $(0.0986)$ & $(0.0188)$ \\
\hline \multirow[t]{2}{*}{$\mathrm{EVI}_{\mathrm{t}-1}$} & 4.369 & $7.750 * * *$ \\
\hline & $(8.977)$ & $(2.194)$ \\
\hline \multirow[t]{2}{*}[\mathrm{EVI}_{\mathrm{t}-1}]{$^{2}$} & -14.38 & $-11.59 * * *$ \\
\hline & $(10.60)$ & $(2.858)$ \\
\hline \multirow[t]{2}{*}{$\mathrm{GCONS}_{\mathrm{t}-1}$} & $0.104^{* * *}$ & -0.00499 \\
\hline & $(0.0385)$ & $(0.00773)$ \\
\hline \multirow[t]{2}{*}{ FINPOL $_{\mathrm{t}-1}$} & 0.567 & -0.0160 \\
\hline & $(0.594)$ & $(0.176)$ \\
\hline \multirow[t]{2}{*}{$\mathrm{ODA}_{\mathrm{t}-1}$} & -0.00117 & $0.0180 * *$ \\
\hline & $(0.00665)$ & $(0.00816)$ \\
\hline \multirow[t]{2}{*}{$\mathrm{OPEN}_{\mathrm{t}-1}$} & $0.0256 * * *$ & $-8.99 \mathrm{e}-05$ \\
\hline & $(0.00638)$ & $(0.00163)$ \\
\hline \multirow[t]{2}{*}{$\mathrm{INFL}_{\mathrm{t}-1}$} & $-0.725^{* *}$ & $0.162^{* * *}$ \\
\hline & $(0.296)$ & $(0.0346)$ \\
\hline \multirow[t]{2}{*}{ TERMS } & 0.00236 & $-0.00477 * * *$ \\
\hline & $(0.00835)$ & $(0.00161)$ \\
\hline \multirow[t]{2}{*}{ Constant } & $14.47 * * *$ & 0.182 \\
\hline & $(4.774)$ & $(0.768)$ \\
\hline Observations - Countries & $484-117$ & $473-106$ \\
\hline Within R-squared & 0.1240 & \\
\hline Pseudo R-squared & & 0.4186 \\
\hline
\end{tabular}

Note: ${ }^{*}$-value $<0: 1 ;{ }^{* *} p$-value $<0: 05 ;{ }^{* * *}$-value $<0: 01$. Robust Standard errors are in parenthesis. For the Random effects estimator, standard errors are clustered at the country level. The Pseudo R2 bas been computed for the regression based on the FGLS estimator as the correlation coefficient between the dependent variable and its predicted values. Time dummies have been included in the regressions based on the random effects estimator and the FGLS estimator. Note that for the sake of the analysis, we have re-scaled the variable "EVI", including by dividing the original EVI variable by 100. 
Table 2: Effect of productive capacities and structural economic vulnerability on economic growth_over the full sample

Estimator: Two-Step System GMM

\begin{tabular}{|c|c|c|c|c|}
\hline Variables & GROWTH & GROWTH & GROWTH & GROWTH \\
\hline & (1) & (2) & (3) & (4) \\
\hline \multirow[t]{2}{*}{ GROWTH $_{\mathrm{t}-1}$} & $0.249^{* * *}$ & $0.205^{* * *}$ & $0.247^{* * *}$ & $0.229 * * *$ \\
\hline & $(0.0173)$ & $(0.0128)$ & $(0.0163)$ & $(0.0177)$ \\
\hline \multirow[t]{2}{*}{ PCI } & $0.143^{* * *}$ & $0.236^{* * *}$ & $0.318^{* * *}$ & $0.424^{* * *}$ \\
\hline & $(0.0362)$ & $(0.0270)$ & $(0.0318)$ & $(0.0363)$ \\
\hline \multirow[t]{2}{*}{ EVI } & $3.631 * * *$ & $25.84 * * *$ & $31.67 * * *$ & $35.69 * * *$ \\
\hline & $(0.869)$ & $(1.964)$ & $(3.458)$ & $(3.154)$ \\
\hline \multirow[t]{2}{*}[\mathrm{EVI}]{$^{2}$} & & $-24.45^{* * *}$ & $-31.42^{* * *}$ & $-34.36^{* * *}$ \\
\hline & & $(2.120)$ & $(3.627)$ & $(3.550)$ \\
\hline \multirow[t]{2}{*}{ PCI*LDC } & & & & $0.279 * * *$ \\
\hline & & & & $(0.0585)$ \\
\hline \multirow[t]{2}{*}{$\mathrm{LDC}$} & & & & $-4.762 * * *$ \\
\hline & & & & $(1.403)$ \\
\hline \multirow[t]{2}{*}{ GCONS } & -0.0168 & $5.74 \mathrm{e}-05$ & $-0.169 * * *$ & $-0.188^{* * *}$ \\
\hline & $(0.0242)$ & $(0.0204)$ & $(0.0204)$ & $(0.0178)$ \\
\hline \multirow[t]{2}{*}{ FINPOL } & -0.420 & -0.121 & $-0.552^{*}$ & $-1.253^{* * *}$ \\
\hline & $(0.291)$ & $(0.243)$ & $(0.301)$ & $(0.298)$ \\
\hline \multirow[t]{2}{*}{ ODA } & 0.00360 & 0.00225 & $0.0654 * * *$ & $0.0447 * * *$ \\
\hline & $(0.00449)$ & $(0.00386)$ & $(0.00491)$ & $(0.00559)$ \\
\hline \multirow[t]{2}{*}{ OPEN } & $0.0173 * * *$ & $0.0121 * * *$ & $0.0145^{* * *}$ & $0.00918^{* * *}$ \\
\hline & $(0.00216)$ & $(0.00130)$ & $(0.00259)$ & $(0.00185)$ \\
\hline \multirow[t]{2}{*}{ INFL } & $-0.888^{* * *}$ & $-0.864 * * *$ & $-0.709 * * *$ & $-0.687 * * *$ \\
\hline & $(0.0880)$ & $(0.0704)$ & $(0.0936)$ & $(0.0741)$ \\
\hline \multirow[t]{2}{*}{ TERMS } & 0.00171 & -0.00116 & $0.00464 * * *$ & $0.00527 * * *$ \\
\hline & $(0.00117)$ & $(0.000841)$ & $(0.00125)$ & $(0.00115)$ \\
\hline Observations - Countries & $486-117$ & $486-117$ & $486-117$ & $486-117$ \\
\hline AR1 (P-Value) & 0.0047 & 0.0063 & 0.0033 & 0.0038 \\
\hline AR2 (P-Value) & 0.1271 & 0.1392 & 0.3836 & 0.3280 \\
\hline AR3 (P-Value) & 0.1908 & 0.1947 & 0.2924 & 0.3128 \\
\hline OID (P-Value) & 0.1435 & 0.1798 & 0.4175 & 0.4428 \\
\hline
\end{tabular}

Note: ${ }^{*}$-value $<0.1 ; * *$-value $<0.05$; ***p-value $<0.01$. Robust Standard Errors are in parenthesis. In the two-step system GMM estimations, the variable "PCI", "EVI" and its squared term, "GCONS", "FINPOL", "ODA", "OPEN", "INFL", and the interaction variables have been treated as endogenous. have been treated as endogenous. Time dummies have been included in the regressions. The latter have used a maximum of 3 lags of the dependent variable as instruments, and 3 lags of endogenous variables as instruments. For the sake of the analysis, we have re-scaled the variable "EVI", including by dividing the original EVI variable by 100. All regressions also include the dummy capturing outliers as well as the interaction between this dummy with the variables "PCI", "EVI" and its squared term, and all these variables have been treated as endogenous. The estimates associated with these variables have not been reported in order to save space, and could be obtained upon request. 
Table 3: Effect of the components of overall productive capacities and structural economic vulnerability on economic growth, including in LDCs versus NonLDCs

Estimator: Two-Step System GMM

\begin{tabular}{|c|c|c|c|c|c|c|c|c|}
\hline & \multicolumn{8}{|c|}{ Regressions' results of model (1) specifications where "PCI" is replaced with each of its components ("COMP") } \\
\hline & \multicolumn{8}{|c|}{ Dependent variable: GROWTH } \\
\hline & HUMCAP & NATURAL & ENERG & TRANSP & ICT & INST & PRIVATE & SCI \\
\hline & $(1)$ & $(2)$ & $(3)$ & $(4)$ & $(5)$ & $(6)$ & $(7)$ & $(8)$ \\
\hline \multirow[t]{2}{*}{ COMP } & $0.181 * * *$ & $-0.0594 * * *$ & $0.107 * * *$ & 0.00990 & $0.147 * * *$ & $0.136^{* * *}$ & 0.0202 & $0.329 * * *$ \\
\hline & $(0.0179)$ & $(0.0160)$ & $(0.0122)$ & $(0.0208)$ & $(0.0279)$ & $(0.0134)$ & $(0.0150)$ & $(0.0262)$ \\
\hline \multirow[t]{2}{*}{ EVI } & $43.68^{* * *}$ & $21.66^{* * *}$ & $30.12^{* * *}$ & $14.17 * * *$ & $26.13 * * *$ & $21.85^{* * *}$ & $25.89 * * *$ & $30.54 * * *$ \\
\hline & $(4.262)$ & $(2.940)$ & $(3.149)$ & $(2.690)$ & $(3.206)$ & (3.553) & $(3.718)$ & $(4.649)$ \\
\hline \multirow[t]{7}{*}[\mathrm{EVI}]{$^{2}$} & $-39.76^{* * *}$ & $-24.79 * * *$ & $-28.12^{* * *}$ & $-14.60^{* * *}$ & $-27.04 * * *$ & $-24.52 * * *$ & $-24.72 * * *$ & $-25.42 * * *$ \\
\hline & $(4.685)$ & $(3.613)$ & $(3.672)$ & $(3.142)$ & $(3.648)$ & $(4.214)$ & $(4.283)$ & $(5.213)$ \\
\hline & & & & & & & & \\
\hline & \multicolumn{8}{|c|}{ Regressions' results of model (1) specifications where "LDC" is interacted with each component ("COMP") of "PCI" } \\
\hline & \multicolumn{8}{|c|}{ Dependent variable: GROWTH } \\
\hline & HUMCAP & NATURAL & ENERG & TRANSP & ICT & INST & PRIVATE & SCI \\
\hline & (1) & $(2)$ & (3) & $(4)$ & (5) & $(6)$ & (7) & $(8)$ \\
\hline \multirow[t]{2}{*}{ COMP } & $0.223^{* * *}$ & $0.0535 * * *$ & $0.348^{* * *}$ & 0.00805 & $0.142^{* * *}$ & $0.123^{* * *}$ & $0.0421 * * *$ & $0.292^{* * *}$ \\
\hline & $(0.0184)$ & $(0.00888)$ & $(0.0332)$ & $(0.0157)$ & $(0.0384)$ & $(0.0149)$ & $(0.0153)$ & $(0.0390)$ \\
\hline \multirow[t]{2}{*}{ COMP*LDC } & $0.192^{* * *}$ & $-0.195^{* * *}$ & $-0.337 * * *$ & $-0.136^{* * *}$ & $0.302^{* * *}$ & 0.0368 & -0.0148 & $0.107^{* *}$ \\
\hline & $(0.0338)$ & $(0.0174)$ & $(0.0372)$ & $(0.0423)$ & $(0.0709)$ & $(0.0247)$ & $(0.0167)$ & $(0.0493)$ \\
\hline \multirow[t]{2}{*}{ EVI } & $20.82^{* * *}$ & $15.54 * * *$ & $33.37 * * *$ & $13.93 * * *$ & $27.17 * * *$ & $18.93 * * *$ & $20.42^{* * *}$ & $20.06^{* * *}$ \\
\hline & (4.415) & (2.992) & (3.180) & $(2.814)$ & $(3.369)$ & (3.139) & (3.358) & $(4.882)$ \\
\hline \multirow[t]{2}{*}[\mathrm{EVI}]{$^{2}$} & $-16.39 * * *$ & $-17.75^{* * *}$ & $-34.69 * * *$ & $-15.91 * * *$ & $-26.22 * * *$ & $-20.50 * * *$ & $-18.96 * * *$ & $-15.84 * * *$ \\
\hline & $(4.393)$ & $(3.682)$ & $(3.442)$ & $(3.116)$ & $(3.578)$ & $(3.691)$ & $(3.769)$ & $(5.654)$ \\
\hline
\end{tabular}

Note: * ${ }^{-v}$ value $<0.1 ; * * p$-value $<0.05 ; * * *$ p-value $<0.01$. Robust Standard Errors are in parenthesis. The variable "COMP" denotes each component of "PCI" introduced once in the growth regression. In the full regressions based on the two-step system GMM estimations, the variables "COMP", "EVI" and its squared term, "GCONS", "FINPOL", "ODA", "OPEN", "INFL" and the interaction variables have been treated as endogenous. Time dummies have been included in the regressions. The latter have used a maximum of 3 lags of the dependent variable as instruments, and 3 lags of endogenous variables as instruments. For the sake of the analysis, we have re-scaled the variable "EVI", including by dividing the original EVI variable by 100. All regressions also include the dummy capturing outliers as well as the interaction between this dummy with the variable "COMP", "EVI" and its squared term, and all these variables have been treated as endogenous. The results of regressions with all regressors could be obtained upon request. All requirements of the two-step system have been met in the regressions. While not presented here in order to save space, all requirements for the consistency of the two-step system GMM approach are met. 
Table 4: Effect of the overall productive capacities on economic growth for varying degrees of structural economic vulnerability

Estimator: Two-Step System GMM

\begin{tabular}{|c|c|}
\hline Variables & GROWTH \\
\hline & (1) \\
\hline \multirow[t]{2}{*}{ GROWTH $_{\mathrm{t}-1}$} & $0.257 * * *$ \\
\hline & $(0.0124)$ \\
\hline \multirow[t]{2}{*}{ PCI } & $0.920 * * *$ \\
\hline & $(0.0913)$ \\
\hline \multirow[t]{2}{*}{ PCI*EVI } & $-4.115^{* * *}$ \\
\hline & $(0.443)$ \\
\hline \multirow[t]{2}{*}{$\mathrm{PCI}^{*}[\mathrm{EVI}]^{2}$} & $5.493 * * *$ \\
\hline & $(0.495)$ \\
\hline \multirow[t]{2}{*}{ EVI } & $124.5^{* * *}$ \\
\hline & $(13.49)$ \\
\hline \multirow[t]{2}{*}[\mathrm{EVI}]{$^{2}$} & $-156.3^{* * *}$ \\
\hline & $(14.87)$ \\
\hline \multirow[t]{2}{*}{ GCONS } & $-0.150^{* * *}$ \\
\hline & $(0.0140)$ \\
\hline \multirow[t]{2}{*}{ FINPOL } & $-0.823^{* * *}$ \\
\hline & $(0.208)$ \\
\hline \multirow[t]{2}{*}{ ODA } & $0.0784 * * *$ \\
\hline & $(0.00551)$ \\
\hline \multirow[t]{2}{*}{ OPEN } & $0.0229 * * *$ \\
\hline & $(0.00189)$ \\
\hline \multirow[t]{2}{*}{ INFL } & $-0.589 * * *$ \\
\hline & $(0.0618)$ \\
\hline \multirow[t]{2}{*}{ TERMS } & $0.00604^{* * *}$ \\
\hline & $(0.00117)$ \\
\hline Observations - Countries & $486-117$ \\
\hline AR1 (P-Value) & 0.0032 \\
\hline AR2 (P-Value) & 0.3668 \\
\hline AR3 (P-Value) & 0.2802 \\
\hline OID (P-Value) & 0.2602 \\
\hline
\end{tabular}

Note: ${ }^{*} p$-value $<0.1 ;{ }^{* *} p$-value $<0.05 ;{ }^{* * *}$-value $<0.01$. Robust Standard Errors are in parenthesis. In the two-step system GMM estimations, the variable "PCI", "EVI" and its squared term, "GCONS", "FINPOL", "ODA", "OPEN", "INFL", "FINDEV", and the interaction variable have been treated as endogenous. Time dummies have been included in the regressions. The latter have used a maximum of 3 lags of the dependent variable as instruments, and 3 lags of endogenous variables as instruments. For the sake of the analysis, we have re-scaled the variable "EVI", including by dividing the original EVI variable by 100. All regressions also include the dummy capturing outliers as well as the interaction between this dummy with the variables "PCI", "EVI" and its squared term, and all these variables have been treated as endogenous. The estimates associated with these variables have not been reported in order to save space, and could be obtained upon request. 
Table 5: Effect of productive capacities and structural economic vulnerability on Economic Growth Volatility_over the full sample

Estimators: FE and FGLS

\begin{tabular}{|c|c|c|}
\hline & FE & FGLS \\
\hline \multirow[t]{2}{*}{ Variables } & $\log ($ GRVOL) & $\log ($ GRVOL) \\
\hline & $(1)$ & $(2)$ \\
\hline \multirow{2}{*}{$\log (\text { GRVOL })_{\mathrm{t}-1}$} & 0.0295 & $0.413^{* * *}$ \\
\hline & $(0.0848)$ & $(0.0177)$ \\
\hline \multirow[t]{2}{*}{$\log (\mathrm{PCI})_{\mathrm{t}-1}$} & $-1.576^{*}$ & $-1.117 * * *$ \\
\hline & $(0.867)$ & $(0.0898)$ \\
\hline \multirow[t]{2}{*}{$\log (E V I)_{t-1}$} & $0.467 *$ & $0.266^{* * *}$ \\
\hline & $(0.239)$ & $(0.0337)$ \\
\hline \multirow[t]{2}{*}{$\log (\text { GDPC })_{t-1}$} & $-0.205^{* *}$ & $0.260 * * *$ \\
\hline & $(0.101)$ & $(0.0146)$ \\
\hline \multirow[t]{2}{*}{$\mathrm{OPEN}_{\mathrm{t}-1}$} & 0.00256 & -0.000324 \\
\hline & $(0.00205)$ & $(0.000220)$ \\
\hline \multirow[t]{2}{*}{ FINPOL $_{\mathrm{t}-1}$} & 0.192 & $-0.0583^{* *}$ \\
\hline & $(0.156)$ & $(0.0256)$ \\
\hline \multirow[t]{2}{*}{$\log (\text { ODAVOL })_{\mathrm{t}-1}$} & 0.00171 & $-0.0261 * * *$ \\
\hline & $(0.0200)$ & $(0.00839)$ \\
\hline \multirow[t]{2}{*}{$\log (\text { INFLVOL) })_{t-1}$} & $0.0149 *$ & 0.00637 \\
\hline & $(0.00823)$ & $(0.0121)$ \\
\hline \multirow[t]{2}{*}{ Log(TERMSVOL) } & $0.200 * * *$ & 0.0217 \\
\hline & $(0.0605)$ & $(0.0163)$ \\
\hline \multirow[t]{2}{*}{ Constant } & $5.836^{* *}$ & $1.129 * * *$ \\
\hline & $(2.733)$ & $(0.295)$ \\
\hline Observations - Countries & $493-115$ & $483-105$ \\
\hline Within R-squared & 0.0789 & \\
\hline Pseudo R-squared & & 0.6321 \\
\hline
\end{tabular}

Note: ${ }^{*} p$-value $<0: 1 ;{ }^{* *}$-value $<0: 05 ;{ }^{* *}$-v-value $<0: 01$. Robust Standard errors are in parenthesis. For the Random effects estimator, standard errors are clustered at the country level. The Psendo R2 has been computed for the regression based on the FGLS estimator as the correlation coefficient between the dependent variable and its predicted values. Time dummies have been included in the regressions based on the random effects estimator and the FGLS estimator. Note that for the sake of the analysis, we have re-scaled the variable "EVI", including by dividing the original EVI variable by 100. 
Table 6: Effect of the overall productive capacities on economic growth volatility_Over the full sample

Estimator: Two-Step System GMM

\begin{tabular}{|c|c|c|c|}
\hline Variables & $\log ($ GRVOL $)$ & $\log ($ GRVOL $)$ & $\log ($ GRVOL $)$ \\
\hline & $(1)$ & $(2)$ & $(3)$ \\
\hline \multirow[t]{2}{*}{$\log (\text { GRVOL })_{t-1}$} & $0.203^{* * *}$ & $0.197 * * *$ & $0.188^{* * *}$ \\
\hline & $(0.0125)$ & $(0.0113)$ & $(0.0168)$ \\
\hline \multirow[t]{2}{*}{$\log (\mathrm{PCI})$} & $-1.031 * * *$ & $-1.217 * * *$ & $-0.568^{* *}$ \\
\hline & $(0.241)$ & $(0.274)$ & $(0.260)$ \\
\hline \multirow[t]{2}{*}{$\log (\mathrm{EVI})$} & $0.627 * * *$ & $0.512^{* * *}$ & $0.668^{* * *}$ \\
\hline & $(0.187)$ & $(0.101)$ & $(0.190)$ \\
\hline \multirow[t]{2}{*}[\mathrm{Log}(\mathrm{PCI})]{$^{* \mathrm{LDC}}$} & & & $-1.150 * * *$ \\
\hline & & & $(0.367)$ \\
\hline \multirow[t]{2}{*}[\operatorname{Log}(\mathrm{EVI})]{$^{* \mathrm{LDC}}$} & & & $-0.657 * *$ \\
\hline & & & $(0.328)$ \\
\hline \multirow[t]{2}{*}{ LDC } & & & $6.086^{* * *}$ \\
\hline & & & $(2.091)$ \\
\hline \multirow[t]{2}{*}{$\log (\mathrm{GDPC})$} & $0.102^{*}$ & $0.150 * * *$ & $0.127 * *$ \\
\hline & $(0.0570)$ & $(0.0525)$ & $(0.0555)$ \\
\hline \multirow[t]{2}{*}{ OPEN } & 0.000872 & 0.000436 & 0.000643 \\
\hline & $(0.000901)$ & $(0.000881)$ & $(0.000939)$ \\
\hline \multirow[t]{2}{*}{ FINPOL } & 0.154 & $0.254^{* * *}$ & $0.240^{* *}$ \\
\hline & $(0.0966)$ & $(0.0867)$ & $(0.113)$ \\
\hline \multirow[t]{2}{*}{$\log ($ ODAVOL $)$} & $0.0839 * * *$ & 0.00168 & 0.0157 \\
\hline & $(0.0224)$ & $(0.0219)$ & $(0.0238)$ \\
\hline \multirow[t]{2}{*}{ Log(INFLVOL) } & $0.0615^{* * *}$ & $0.0580^{* * *}$ & 0.0197 \\
\hline & $(0.0180)$ & $(0.0213)$ & $(0.0189)$ \\
\hline \multirow[t]{2}{*}{ Log(TERMSVOL) } & $0.0760 * * *$ & $0.0792 * * *$ & $0.0830 * * *$ \\
\hline & $(0.0221)$ & $(0.0195)$ & $(0.0187)$ \\
\hline Observations - Countries & $495-115$ & $495-115$ & $495-115$ \\
\hline AR1 (P-Value) & 0.0000 & 0.0000 & 0.0000 \\
\hline AR2 (P-Value) & 0.2263 & 0.4460 & 0.4798 \\
\hline AR3 (P-Value) & 0.7461 & 0.8832 & 0.8051 \\
\hline OID (P-Value) & 0.3524 & 0.5609 & 0.5491 \\
\hline
\end{tabular}

Note: ${ }^{*}$-value $<0.1 ; * *$-value $<0.05 ; * * *$-value $<0.01$. Robust Standard Errors are in parenthesis. In the two-step system GMM estimations, the variable "PCI", "EVI", "GDPC", "FINPOL", "ODAVOL", "OPEN", "INFLVOL" and the interaction variables have been treated as endogenous. Time dummies have been included in the regressions. The latter have used a maximum of 3 lags of the dependent variable as instruments, and 3 lags of endogenous variables as instruments. The variable "EVI" has not been re-scaled here, and its values range between 0 and 100. All regressions also include the dummy capturing outliers as well as the interaction between this dummy with the variables "PCI" and "EVI", with these variables having been treated as endogenous. Their estimates have not been reported in order to save space, and could be obtained upon request. 
Table 7: Effect of the components of the overall productive capacities on economic growth volatility, including in LDCs versus NonLDCs Estimator. Two-Step System GMM

\begin{tabular}{|c|c|c|c|c|c|c|c|c|}
\hline & \multicolumn{8}{|c|}{ Regressions' results of model (1) specifications where "PCI" is replaced with each of its components ("COMP") (in Logs) } \\
\hline & \multicolumn{8}{|c|}{ Dependent variable: $\log ($ GRVOL) } \\
\hline & HUMCAP & NATURAL & ENERG & TRANSP & ICT & INST & PRIVATE & SCI \\
\hline & (1) & $(2)$ & (3) & (4) & (5) & (6) & (7) & (8) \\
\hline \multirow{2}{*}{$\log (\mathrm{COMP})$} & $-0.767 * *$ & 0.396 & $-0.655^{* * *}$ & $0.334 * *$ & 0.0525 & $-0.581 * * *$ & $-0.699 * *$ & $-0.753 * * *$ \\
\hline & $(0.358)$ & $(0.276)$ & $(0.192)$ & $(0.135)$ & (0.193) & $(0.140)$ & $(0.320)$ & $(0.122)$ \\
\hline \multirow[t]{6}{*}{$\log (\mathrm{EVI})$} & $0.318^{*}$ & $0.620 * * *$ & $0.479 * * *$ & $0.617 * * *$ & $0.737 * * *$ & $0.468^{* * *}$ & $0.507 * * *$ & 0.201 \\
\hline & $(0.179)$ & $(0.138)$ & $(0.179)$ & $(0.158)$ & $(0.178)$ & $(0.154)$ & $(0.185)$ & $(0.170)$ \\
\hline & \multicolumn{8}{|c|}{ Regressions' results of model (1) specifications where "LDC" is interacted with each component ("COMP") of "PCI" (in Logs } \\
\hline & \multicolumn{8}{|c|}{ Dependent variable: $\log (\mathrm{GRVOL})$} \\
\hline & HUMCAP & NATURAL & ENERG & TRANSP & ICT & INST & PRIVATE & SCI \\
\hline & (1) & (2) & (3) & (4) & $(5)$ & (6) & $(7)$ & $(8)$ \\
\hline \multirow[t]{2}{*}{$\log (\mathrm{COMP})$} & $-0.679 * * *$ & $1.150^{* * *}$ & $-1.643^{* * *}$ & $0.413^{* * *}$ & $0.168^{*}$ & $-0.365^{* * *}$ & 0.0372 & $0.551 * * *$ \\
\hline & $(0.214)$ & $(0.174)$ & $(0.145)$ & $(0.0933)$ & $(0.0967)$ & $(0.0898)$ & $(0.183)$ & $(0.201)$ \\
\hline \multirow[t]{2}{*}[\mathrm{Log}(\mathrm{COMP})]{$^{*} \mathrm{LDC}$} & $0.412^{* * *}$ & -0.428 & $1.520^{* * *}$ & -0.214 & $0.158^{*}$ & $-0.645^{* * *}$ & $-1.744 * * *$ & $-1.180 * * *$ \\
\hline & $(0.154)$ & $(0.319)$ & $(0.157)$ & $(0.150)$ & $(0.0822)$ & $(0.197)$ & $(0.260)$ & $(0.181)$ \\
\hline \multirow[t]{2}{*}{$\log (E V I)$} & $0.451 * * *$ & $0.717^{* * *}$ & $0.648^{* * *}$ & $0.758^{* * *}$ & $0.776^{* * *}$ & $0.320^{* * *}$ & $0.778^{* * *}$ & $0.708^{* * *}$ \\
\hline & $(0.0680)$ & $(0.0740)$ & $(0.0998)$ & $(0.0990)$ & $(0.0918)$ & $(0.0964)$ & $(0.100)$ & $(0.0993)$ \\
\hline
\end{tabular}

Note: *p-value $<0.1$; **p-value $<0.05$; ***p-value $<0.01$. Robust Standard Errors are in parenthesis. The variable "COMP" denotes each component of "PCI" introduced once in the growth regression. In the full regressions based on the two-step system GMM estimations, the variables "COMP" (in $\log )$, "Log(EVI)", "Log(GDPC)", "FINPOL", "Log(ODAVOL)", "OPEN", "Log(INFLVOL)" and the interaction variables have been treated as endogenous. Time dummies have been included in the regressions. The latter have used a maximum of 3 lags of the dependent variable as instruments, and 3 lags of endogenous variables as instruments. The variable "EVI" bas not been re-scaled here, and its values range between 0 and 100. All regressions also include the dummy capturing outliers as well as the interaction between this dummy with the variables "PCI" and "EVI", with these variables having been treated as endogenous. The outcomes of the full regressions (i.e., with all regressors) could be obtained upon request. While not presented here in order to save space, all requirements for the consistency of the two-step system GMM approach are met. 
Table 8: Joint effect of the overall productive capacities and structural economic vulnerability on economic growth volatility_Over the full sample

Estimator: Two-Step System GMM

\begin{tabular}{|c|c|}
\hline Variables & Log(GRVOL) \\
\hline & $(1)$ \\
\hline \multirow[t]{2}{*}{$\log (\text { GRVOL })_{t-1}$} & $0.202^{* * *}$ \\
\hline & $(0.00879)$ \\
\hline \multirow[t]{2}{*}{$\log ($ PCI $)$} & $2.873 * *$ \\
\hline & $(1.216)$ \\
\hline \multirow[t]{2}{*}{$\log (\mathrm{EVI})$} & $4.501 * * *$ \\
\hline & $(1.026)$ \\
\hline \multirow[t]{2}{*}[\operatorname{Log}(\mathrm{PCI})]{$^{*}[\log (\mathrm{EVI})]$} & $-1.411 * * *$ \\
\hline & $(0.314)$ \\
\hline \multirow[t]{2}{*}{$\log ($ GDPC) } & $0.237 * * *$ \\
\hline & $(0.0400)$ \\
\hline \multirow[t]{2}{*}{ OPEN } & $0.00109 *$ \\
\hline & $(0.000643)$ \\
\hline \multirow[t]{2}{*}{ FINPOL } & $0.273^{* * *}$ \\
\hline & $(0.0583)$ \\
\hline \multirow[t]{2}{*}{ Log(ODAVOL) } & $-0.0267 * *$ \\
\hline & $(0.0135)$ \\
\hline \multirow[t]{2}{*}{ Log(INFLVOL) } & $0.0645 * * *$ \\
\hline & $(0.0167)$ \\
\hline \multirow[t]{2}{*}{ Log(TERMSVOL) } & $0.0735^{* * *}$ \\
\hline & $(0.0150)$ \\
\hline Observations - Countries & $495-115$ \\
\hline AR1 (P-Value) & 0.0000 \\
\hline AR2 (P-Value) & 0.5378 \\
\hline AR3 (P-Value) & 0.8497 \\
\hline OID (P-Value) & 0.8227 \\
\hline
\end{tabular}

Note: ${ }^{*}$-value $<0.1$; ${ }^{* *}$-value $<0.05$; ${ }^{* * *}$-value $<0.01$. Robust Standard Errors are in parenthesis. In the two-step system GMM estimations, the variable "PCI", "EVI", "GDPC", "FINPOL", "ODAVOL", "OPEN", "INFLVOL" and the interaction variables have been treated as endogenous. Time dummies have been included in the regressions. The latter have used a maximum of 3 lags of the dependent variable as instruments, and 3 lags of endogenous variables as instruments. The variable "EVI" has not been re-scaled here, and its values range between 0 and 100. All regressions also include the dummy capturing outliers as well as the interaction between this dummy with the variables "PCI" and "EVI", with these variables having been treated as endogenous. Their estimates have not been reported in order to save space, and could be obtained upon request. 
Appendix 1: Definition and Source of variables

\section{APPENDICES}

\begin{tabular}{|c|c|c|}
\hline Variables & Definition & Source \\
\hline GROWTH & Gross Domestic Product (GDP) per capita growth (annual \%) & $\begin{array}{c}\text { Data extracted from the World } \\
\text { Development Indicators (WDI) of the } \\
\text { World Bank }\end{array}$ \\
\hline PCI & $\begin{array}{l}\text { This is the overall Productive Capacity Index. It measures the level of productive capacities along } \\
\text { three pillars: "the productive resources, entrepreneurial capabilities and production linkages which } \\
\text { together determine the capacity of a country to produce goods and services and enable it to grow } \\
\text { and develop" (UNCTAD, 2006). } \\
\text { It is computed as a geometric average of eight domains or categories, namely, Information } \\
\text { communication and technologies (ICTs), structural change, natural capital, human capital, energy, } \\
\text { transport, the private sector and institutions. Each category index is obtained using the principal } \\
\text { components extracted from the underlying indicators, weighted by their capacity to explain the } \\
\text { variance of the original data. The category indices are normalized into 0-100 intervals. } \\
\text { The components of "PCI" include ICTs (denoted "ICT"), structural change (denoted "SCI"), } \\
\text { natural capital (denoted "NATCAP"), human capital (denoted "HUMCAP"), energy (denoted } \\
\text { "ENERG"), transport (denoted "TRANSP"), the private sector (denoted "PRIVATE"), and } \\
\text { institutions (denoted "INST"). For a comprehensive description of the methodology used to } \\
\text { compute the indicator "PCI", see UNCTAD (2020). }\end{array}$ & $\begin{array}{l}\text { United Nations Conference on Trade and } \\
\text { Development (UNCTAD) Statistics portal: } \\
\underline{\text { https://unctadstat.unctad.org/wds/Report }} \\
\underline{\text { Folders/reportFolders.aspx }}\end{array}$ \\
\hline EVI & $\begin{array}{l}\text { This is indicator of structural economic vulnerability, also referred to as the Economic } \\
\text { Vulnerability Index. It has been set up at the United Nations by the Committee for Development } \\
\text { Policy (CDP), and used by the latter as one of the criteria for identifying LDCs. It has been } \\
\text { computed on a retrospective basis for } 145 \text { developing countries (including } 48 \text { LDCs) by the } \\
\text { "Fondation pour les Etudes et Recherches sur le Developpement International (FERDI)". The } \\
\text { EVI has been computed as the simple arithmetic average of two sub-indexes, namely the intensity } \\
\text { of exposure to shocks (exposure sub-index) and the intensity of exogenous shocks (shocks sub- } \\
\text { index). These two sub-indexes have been calculated using a weighted average of different } \\
\text { component indexes, with the sum of components' weights equals } 1 \text { so that the values of EVI } \\
\text { range between } 0 \text { and } 100 \text {. } \\
\text { The exposure sub-index has five component indexes, and the shocks sub-index has three } \\
\text { component indexes. The five component indexes of the exposure sub-index (with their weights in }\end{array}$ & $\begin{array}{l}\text { Data on EVI is extracted from the database } \\
\text { of the Fondation pour les Etudes et } \\
\text { Recherches sur le Developpement } \\
\text { International (FERDI) - see online at: } \\
\text { https://ferdi.fr/donnees/un-indicateur-de- } \\
\text { vulnerabilite-economique-evi-retrospectif }\end{array}$ \\
\hline
\end{tabular}




\begin{tabular}{|c|c|c|}
\hline & $\begin{array}{l}\text { brackets) are: population size }(25 \%) \text {, remoteness from world markets }(25 \%) \text {, exports concentration } \\
(12.5 \%) \text {, share of agriculture, forestry and fishery in GDP }(12.5 \%) \text { and the share of population } \\
\text { living in low elevated coastal zone }(25 \%) \text {. The three component indexes of the shocks sub-index } \\
\text { (with their weights in brackets) are: the victims of natural disasters }(25 \%) \text {, the instability in the } \\
\text { agricultural production }(25 \%) \text {, and the instability in exports of goods and services }(50 \%) \text {. A rise in } \\
\text { the values of EVI indicate greater structural economic vulnerability. For further details on the } \\
\text { computation of the EVI, see for example Feindouno and Goujon (2016). }\end{array}$ & \\
\hline OPEN & $\begin{array}{c}\text { This is the indicator of trade openness. It is measured by the share (in percentage) of sum of } \\
\text { exports and imports of goods and services in GDP. }\end{array}$ & WDI \\
\hline GCONS & This is the ratio (in percentage) of the general government final consumption expenditure to GDP. & WDI \\
\hline FINOPEN & This is the measure of financial policy, i.e., de jure financial openness. & $\begin{array}{l}\text { This index has been computed by Chinn } \\
\text { and Ito (2006) and updated in July 2020. Its } \\
\text { value ranges between } 0 \text { and } 1 \text {. See: } \\
\text { http://web.pdx.edu/ ito/Chinn- } \\
\text { Ito website.htm } \\
\text { For the purpose of the present study, we } \\
\text { have transformed this index by multiplying } \\
\text { its values by } 100 . \text { So, its values range here } \\
\text { between } 0 \text { and } 100 .\end{array}$ \\
\hline ODA & $\begin{array}{l}\text { This is the net Official Development Assistance (ODA), expressed in constant } 2018 \text { US } \$ \text { prices. } \\
\text { This variable, which we denote "ODA1" contains negative values. Therefore, we have transformed } \\
\text { it using the following formula (see Yeyati et al. 2007; Dabla-Norris et al., 2015): ODA = } \\
\text { sign }(O D A 1) * \log (1+|O D A 1|) \text {, where |ODA1| refers to the absolute value of the variable } \\
\text { "ODA1". }\end{array}$ & $\begin{array}{l}\text { "ODA1" data is extracted from the } \\
\text { database of the Organization for Economic } \\
\text { Cooperation and Development (OECD). } \\
\text { See online at: https://stats.oecd.org/ }\end{array}$ \\
\hline ODAVOL & $\begin{array}{l}\text { This is the measure of the volatility of net Official Development Assistance (ODA), expressed in } \\
\text { constant } 2018 \text { US\$ prices. It has been computed as the rolling standard deviation over a 3-year- } \\
\text { window of the growth rate of variable "ODA1", as defined above. }\end{array}$ & $\begin{array}{l}\text { "ODA1" data is extracted from the } \\
\text { database of the Organization for Economic } \\
\text { Cooperation and Development (OECD). } \\
\text { See online at: https://stats.oecd.org/ }\end{array}$ \\
\hline INFL & $\begin{array}{l}\text { The variable "INFL" is the transformed measure of the annual inflation rate }(\%) \text {. The annual } \\
\text { inflation rate }(\%) \text { is based on Consumer Price Index CPI, where missing values has been replaced } \\
\text { with values of the GDP Deflator (annual \%). The variable "INFL" has been computed using the } \\
\text { following formula: INFL = sign }(\text { INFLATION)* } \log (1+\mid \text { INFLATION|) (2), where }\end{array}$ & $\begin{array}{c}\text { Authors' calculation based on data from the } \\
\text { World Bank Indicators (WDI). }\end{array}$ \\
\hline
\end{tabular}




\begin{tabular}{|c|c|c|}
\hline & $\begin{array}{l}\mid \text { INFLATION } \mid \text { refers to the absolute value of the annual inflation rate }(\%) \text {, denoted } \\
\text { "INFLATION". }\end{array}$ & \\
\hline INFLVOL & $\begin{array}{l}\text { Inflation volatility is calculated as the rolling standard deviation of inflation rate (i.e., } \\
\text { "INFLATION" defined above) over a 3-year-window. }\end{array}$ & $\begin{array}{l}\text { Authors' calculation based on inflation data } \\
\text { extracted from the WDI. }\end{array}$ \\
\hline GDPC & Per capita Gross Domestic Product (constant 2010 US\$). & World Bank Indicators (WDI) \\
\hline OPEN & $\begin{array}{l}\text { Measure of trade openness calculated as the share of sum of exports and imports of goods and } \\
\text { services in GDP. }\end{array}$ & $\begin{array}{l}\text { Authors' calculation based on data extracted } \\
\text { from the WDI }\end{array}$ \\
\hline GRVOL & $\begin{array}{l}\text { Economic growth volatility is calculated as the rolling standard deviation of the annual economic } \\
\text { growth rate "GROWTH" over a 3-year-window. }\end{array}$ & $\begin{array}{l}\text { Authors' calculation based on inflation data } \\
\text { extracted from the WDI. }\end{array}$ \\
\hline TERMS & $\begin{array}{l}\text { This is the measure of terms of trade, i.e., here the net barter terms of trade index }(2000=100) \text {. It } \\
\text { is computed as is calculated as the percentage ratio of the export unit value indexes to the import } \\
\text { unit value indexes, measured relative to the base year } 2000 .\end{array}$ & $\begin{array}{l}\text { Author's calculation based on terms of trade } \\
\text { data extracted from the WDI. }\end{array}$ \\
\hline TERMSVOL & $\begin{array}{l}\text { This is the indicator of terms of trade volatility. It has been computed as the rolling standard } \\
\text { deviation of the growth rate of the index of terms of trade ("TERMS") over 3-year-window. }\end{array}$ & $\begin{array}{l}\text { Authors' calculation based on inflation data } \\
\text { extracted from the WDI. }\end{array}$ \\
\hline
\end{tabular}


Appendix 2a: Descriptive statistics on variables used in the model of economic growth

\begin{tabular}{|c|c|c|c|c|c|}
\hline Variable & Observations & Mean & Standard deviation & Minimum & Maximum \\
\hline GROWTH & 486 & 2.660 & 2.908 & -10.977 & 17.702 \\
\hline PCI & 486 & 26.441 & 5.161 & 12.873 & 41.200 \\
\hline EVI & 486 & 32.771 & 11.488 & 9.794 & 69.985 \\
\hline HUMCAP & 486 & 41.684 & 8.665 & 20.341 & 69.301 \\
\hline NATCAP & 486 & 54.975 & 8.529 & 32.952 & 92.075 \\
\hline ENERG & 486 & 23.701 & 6.429 & 6.771 & 58.484 \\
\hline TRANSP & 486 & 13.811 & 5.949 & 4.522 & 58.009 \\
\hline ICT & 486 & 6.934 & 3.391 & 2.824 & 18.632 \\
\hline INST & 486 & 44.877 & 12.685 & 16.587 & 88.862 \\
\hline PRIVATE & 486 & 74.482 & 8.735 & 38.160 & 91.224 \\
\hline SCI & 486 & 16.834 & 4.731 & 1.880 & 36.890 \\
\hline GCONS & 486 & 14.148 & 6.077 & 2.736 & 56.066 \\
\hline OPEN & 486 & 78.218 & 40.386 & 11.682 & 399.724 \\
\hline INFLATION & 486 & 6.596 & 6.062 & -3.744 & 56.581 \\
\hline TERMS & 486 & 125.983 & 45.718 & 25.086 & 437.699 \\
\hline
\end{tabular}

Appendix 2b: Descriptive statistics on variables used in the models of economic growth volatility

\begin{tabular}{|c|c|c|c|c|c|}
\hline Variable & Observations & Mean & Standard deviation & Minimum & Maximum \\
\hline GRVOL & 495 & 2.465 & 4.593 & 0.134 & 90.645 \\
\hline PCI & 495 & 26.394 & 5.163 & 12.873 & 41.200 \\
\hline HUMCAP & 495 & 41.635 & 8.637 & 20.341 & 69.301 \\
\hline NATCAP & 495 & 54.868 & 8.482 & 32.952 & 92.075 \\
\hline ENERG & 495 & 23.630 & 6.404 & 6.771 & 58.484 \\
\hline TRANSP & 495 & 13.861 & 5.957 & 4.522 & 58.009 \\
\hline ICT & 495 & 6.913 & 3.387 & 2.824 & 18.632 \\
\hline INST & 495 & 44.747 & 12.850 & 12.362 & 88.862 \\
\hline PRIVATE & 495 & 74.489 & 8.698 & 38.160 & 91.224 \\
\hline SCI & 495 & 16.769 & 4.708 & 1.880 & 36.890 \\
\hline EVI & 495 & 32.969 & 11.517 & 9.794 & 69.985 \\
\hline OPEN & 495 & 77.828 & 39.563 & 0.216 & 399.724 \\
\hline FINPOL & 495 & 0.409 & 0.333 & 0.000 & 1.000 \\
\hline GDPC & 495 & 4389.794 & 5450.904 & 218.334 & 58924.130 \\
\hline TERMSVOL & 495 & 0.081 & 0.108 & 0.000 & 2.036 \\
\hline INFLVOL & 495 & 2.031 & 5.596 & 0.045 & 80.980 \\
\hline ODAVOL & 495 & 0.971 & 3.444 & 0.033 & 56.032 \\
\hline GRVOL4 & 495 & 2.716 & 4.303 & 0.158 & 78.977 \\
\hline GRVOL5 & 495 & 2.900 & 4.191 & 0.181 & 68.583 \\
\hline TERMSVOL4 & 495 & 0.086 & 0.100 & 0.000 & 1.779 \\
\hline TERMSVOL5 & 495 & 0.088 & 0.100 & 0.000 & 1.595 \\
\hline INFLVOL4 & 495 & 2.256 & 6.810 & 0.052 & 104.247 \\
\hline INFLVOL5 & 495 & 2.449 & 7.253 & 0.077 & 98.958 \\
\hline ODAVOL4 & 495 & 1.043 & 3.664 & 0.057 & 48.063 \\
\hline ODAVOL5 & 495 & 1.071 & 3.445 & 0.057 & 42.814 \\
\hline
\end{tabular}


Appendix 3: List of countries contained in the Full Sample and sub-sample of LDCs

\begin{tabular}{|c|c|c|c|}
\hline \multicolumn{3}{|c|}{ Full sample } & LDCs \\
\hline Algeria & Fiji & Namibia & Angola \\
\hline Angola & Gabon & Nepal & Bangladesh \\
\hline Argentina & Gambia, The & Nicaragua & Benin \\
\hline Armenia & Georgia & Niger & Bhutan \\
\hline Azerbaijan & Ghana & Nigeria & Burkina Faso \\
\hline Bahamas, The & Guatemala & Oman & Burundi \\
\hline Bahrain & Guinea & Pakistan & Cambodia \\
\hline Bangladesh & Guinea-Bissau & Panama & $\begin{array}{c}\text { Central African } \\
\text { Republic }\end{array}$ \\
\hline Barbados & Guyana & Papua New Guinea & Chad \\
\hline Belize & Haiti & Paraguay & Comoros \\
\hline Benin & Honduras & Peru & Congo, Dem. Rep. \\
\hline Bhutan & India & Philippines & Djibouti \\
\hline Bolivia & Indonesia & Rwanda & Ethiopia \\
\hline $\begin{array}{l}\text { Bosnia and } \\
\text { Herzegovina }\end{array}$ & Iran, Islamic Rep. & Saudi Arabia & Gambia, The \\
\hline Brazil & Israel & Senegal & Guinea \\
\hline Burkina Faso & Jamaica & Seychelles & Guinea-Bissau \\
\hline Burundi & Jordan & Sierra Leone & Haiti \\
\hline Cabo Verde & Kazakhstan & Singapore & Lao PDR \\
\hline Cambodia & Kenya & Solomon Islands & Lesotho \\
\hline Cameroon & Korea, Rep. & South Africa & Liberia \\
\hline $\begin{array}{c}\text { Central African } \\
\text { Republic }\end{array}$ & Kyrgyz Republic & Sri Lanka & Madagascar \\
\hline Chad & Lao PDR & Sudan & Malawi \\
\hline Chile & Lebanon & Suriname & Mali \\
\hline China & Lesotho & Syrian Arab Republic & Mauritania \\
\hline Colombia & Liberia & Tajikistan & Mozambique \\
\hline Comoros & Libya & Tanzania & Myanmar \\
\hline Congo, Dem. Rep. & Madagascar & Thailand & Nepal \\
\hline Congo, Rep. & Malawi & Togo & Niger \\
\hline Costa Rica & Malaysia & Tonga & Rwanda \\
\hline Cote d'Ivoire & Maldives & Tunisia & Senegal \\
\hline Cyprus & Mali & Turkey & Sierra Leone \\
\hline Djibouti & Marshall Islands & Turkmenistan & Solomon Islands \\
\hline Dominican Republic & Mauritania & Uganda & Sudan \\
\hline Ecuador & Mauritius & United Arab Emirates & Tanzania \\
\hline Egypt, Arab Rep. & Mexico & Uruguay & Togo \\
\hline El Salvador & Mongolia & Uzbekistan & Uganda \\
\hline Equatorial Guinea & Morocco & Venezuela, RB & Zambia \\
\hline Eswatini & Mozambique & Vietnam & \\
\hline Ethiopia & Myanmar & Zambia & \\
\hline
\end{tabular}




\section{FIGURES}

Figure 1: Productive capacities, structural economic vulnerability, economic growth and economic growth volatility_Over the full sample

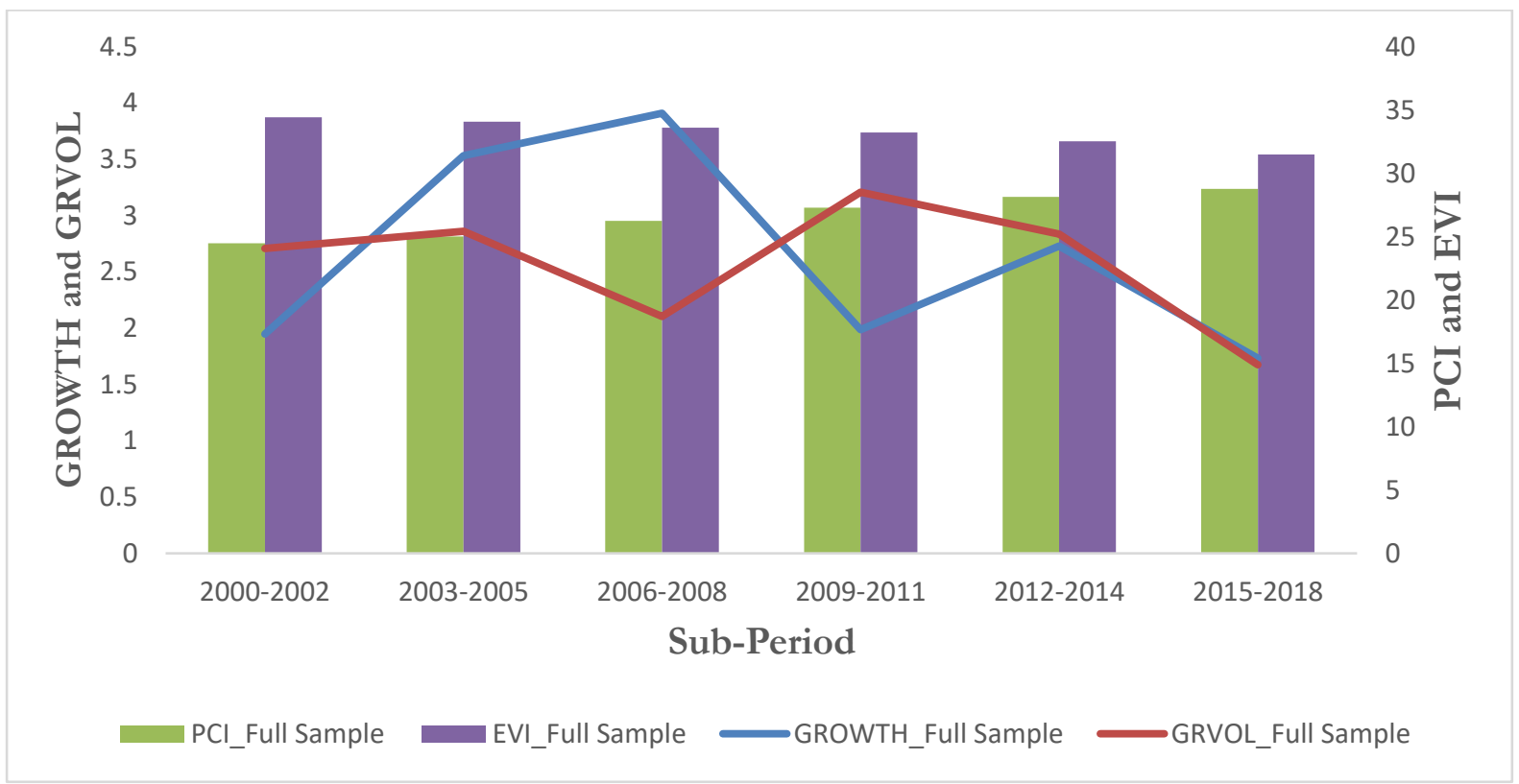

Source: Author

Figure 2: Productive capacities, structural economic vulnerability, economic growth and economic growth volatility_Over the sub-sample of LDCs

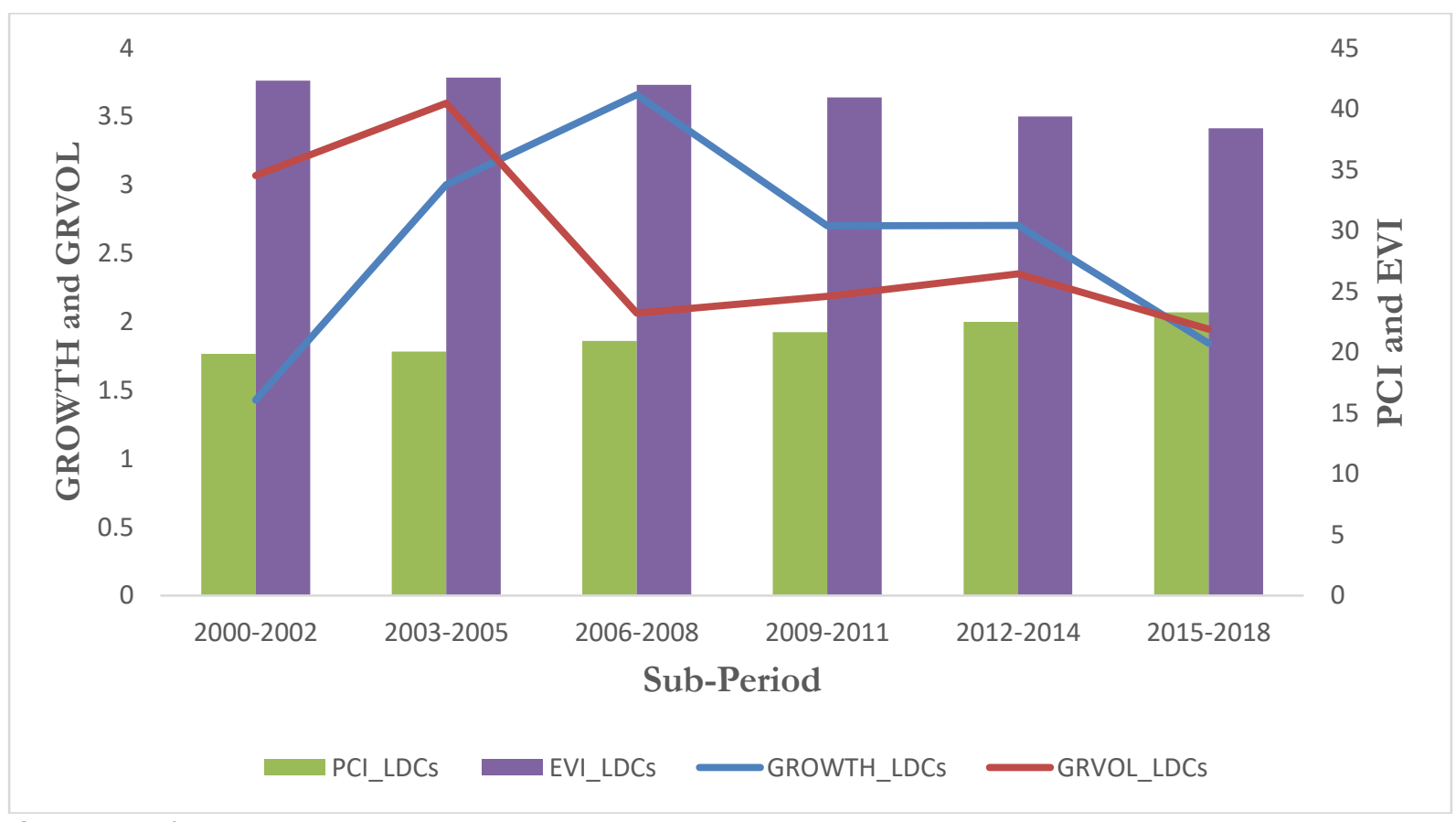

Source: Author 
Figure 3: Productive capacities, structural economic vulnerability, economic growth and economic growth volatility_Over the sub-sample of NonLDCs

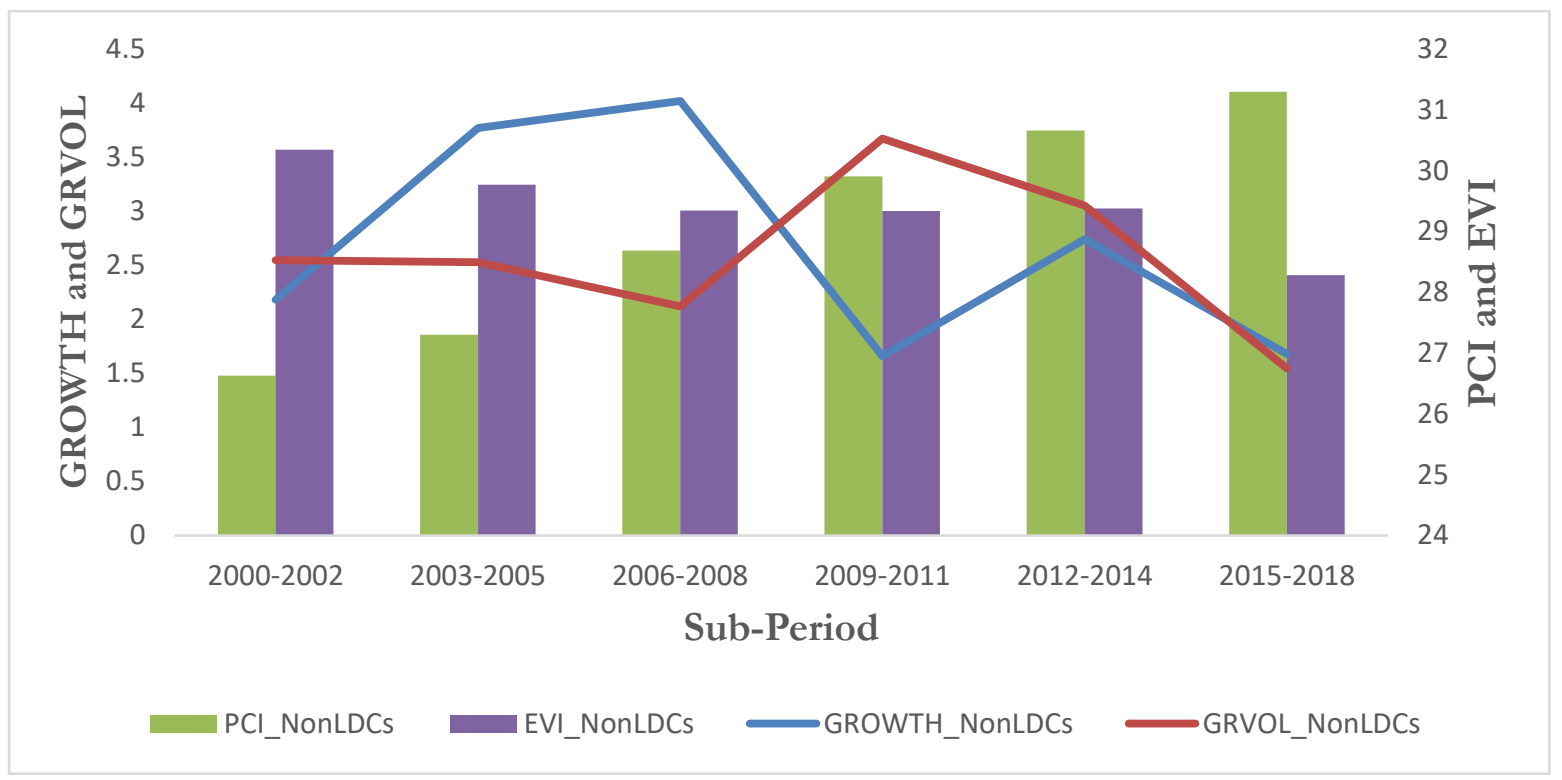

Source: Author

Figure 4: Cross plot between productive capacities, structural economic vulnerability and economic growth_Over the full sample and sub-samples of LDCs and NonLDCs
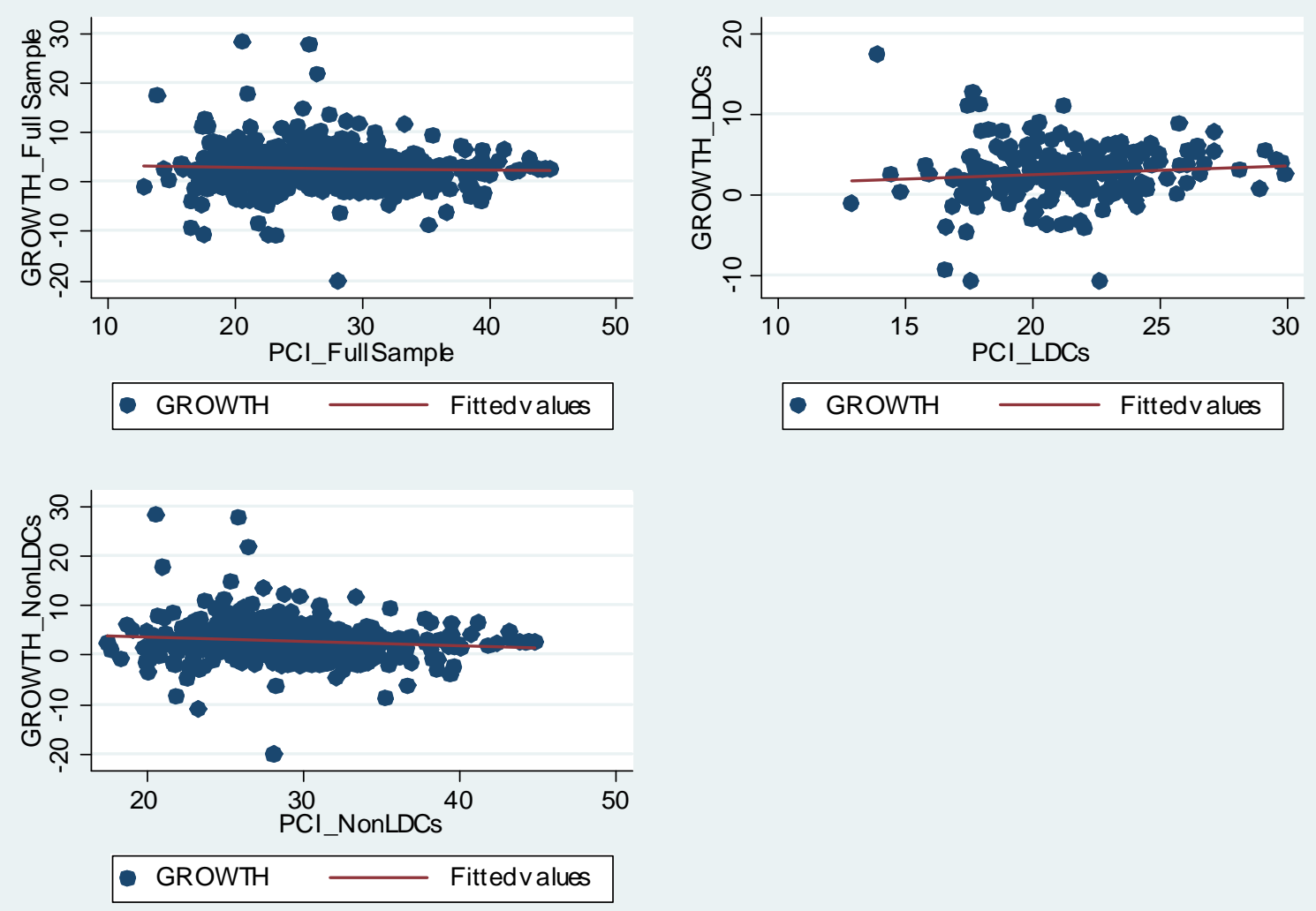

Source: Author 
Figure 5: Cross plot between structural economic vulnerability and economic growth_Over the full sample
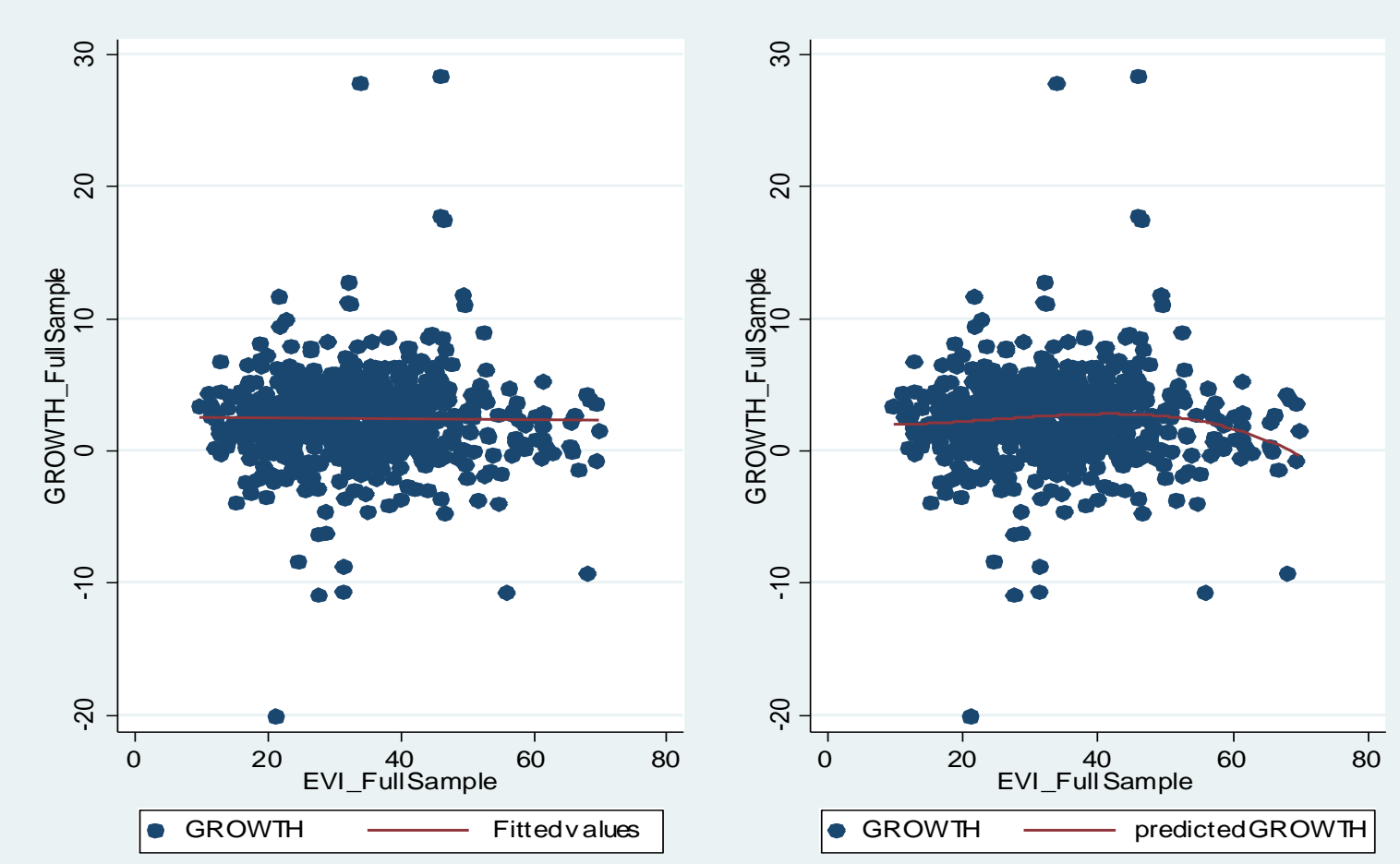

Source: Author

Figure 6: Cross plot between productive capacities, structural economic vulnerability and economic growth volatility_Over the full sample and sub-samples of LDCs and NonLDCs
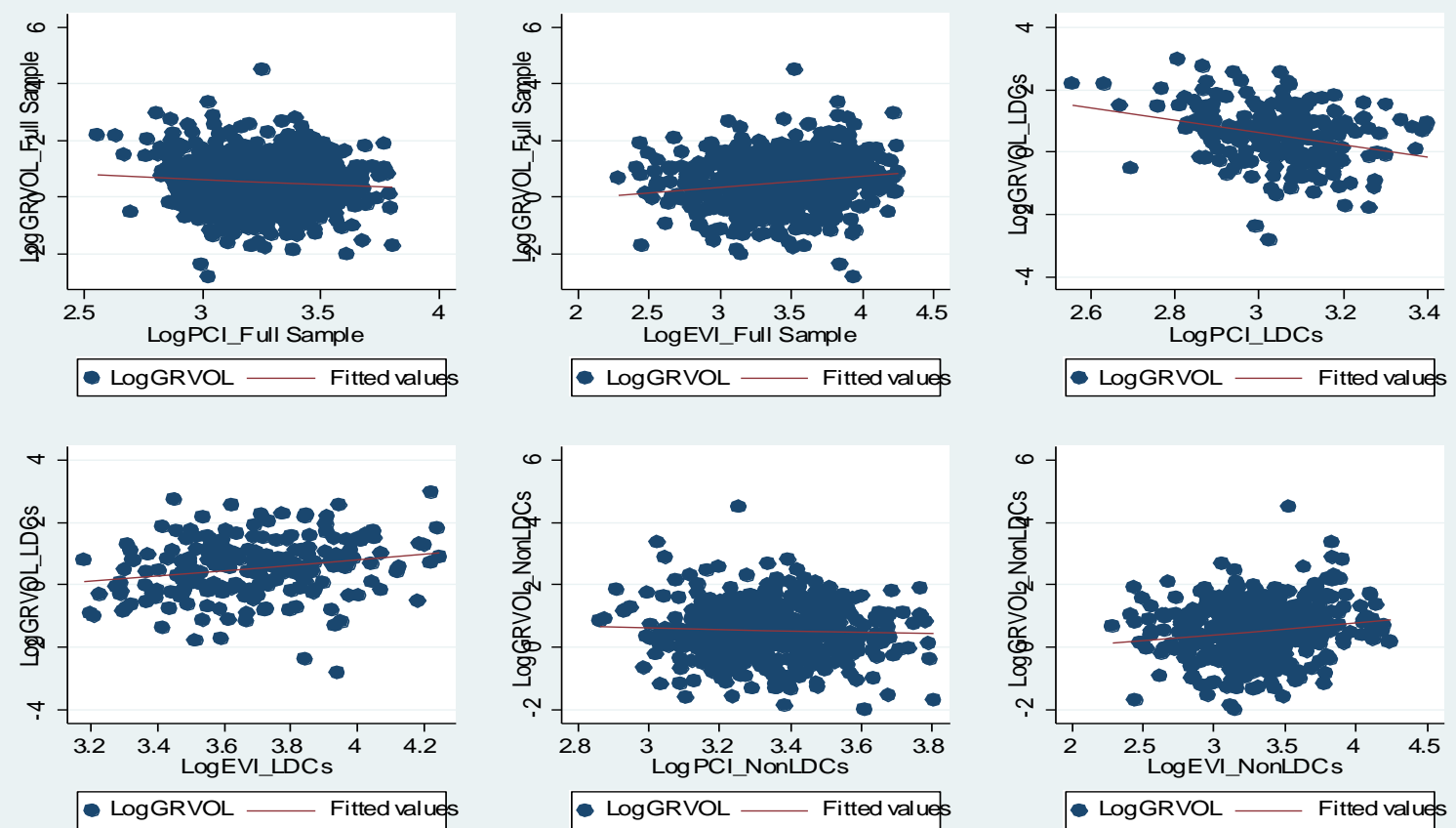

Source: Author 
Figure 7: Marginal Impact of "EVI" on "GROWTH", for varying degrees of EVI

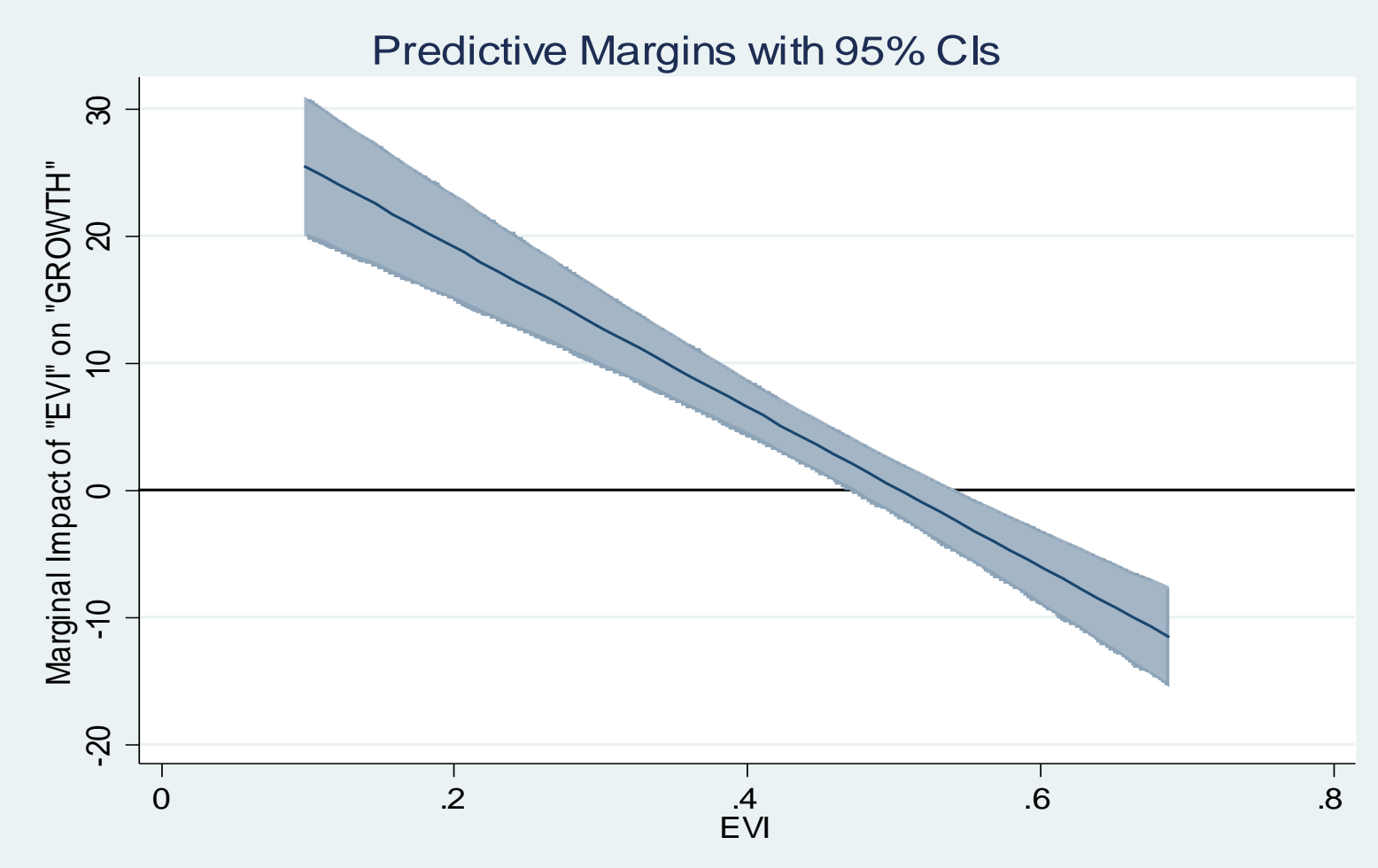

Source: Author

Figure 8: Marginal Impact of "PCI" on "GROWTH", for varying degrees of EVI

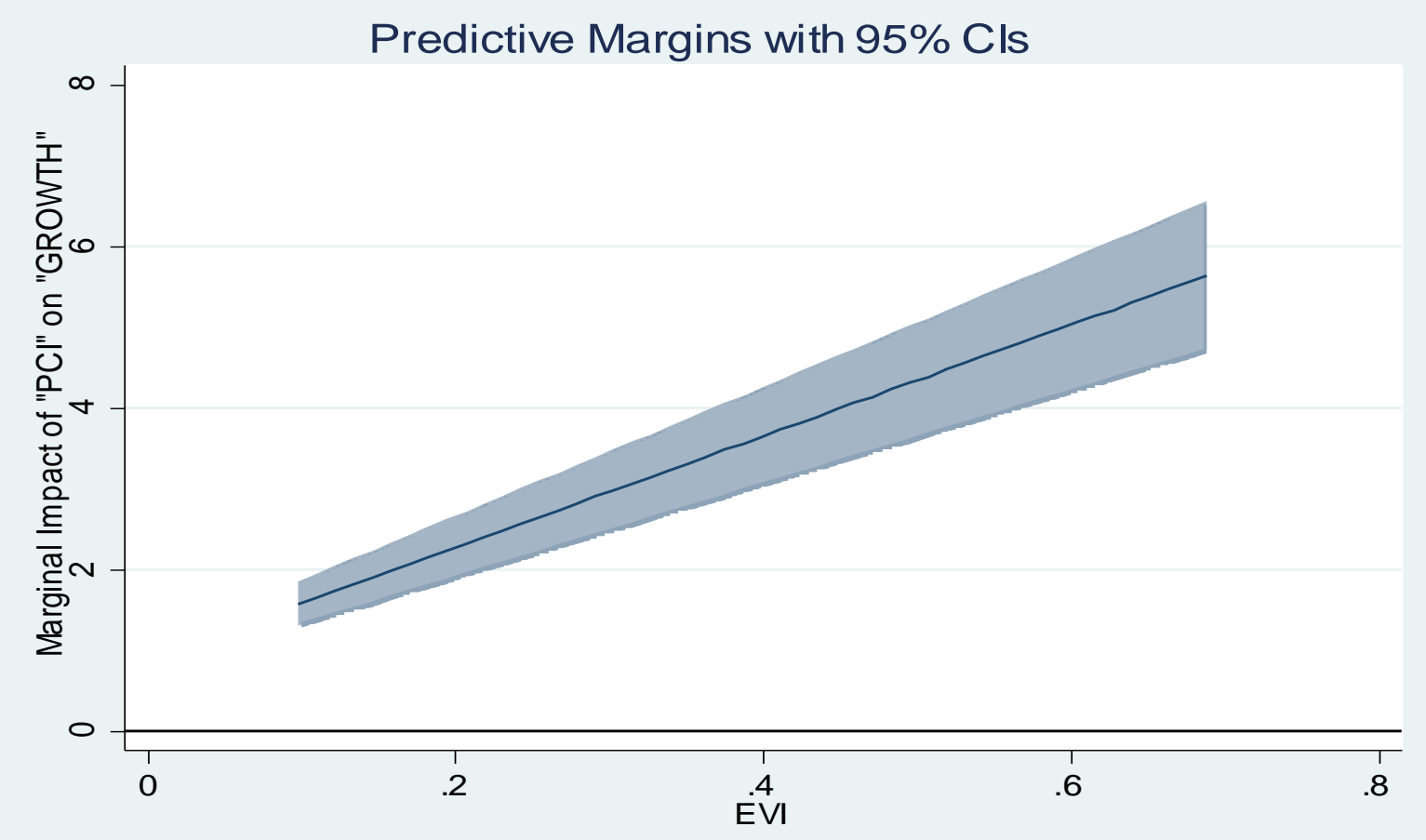

Source: Author 
Figure 9: Marginal Impact of "PCI" on "GRVOL", for varying degrees of EVI

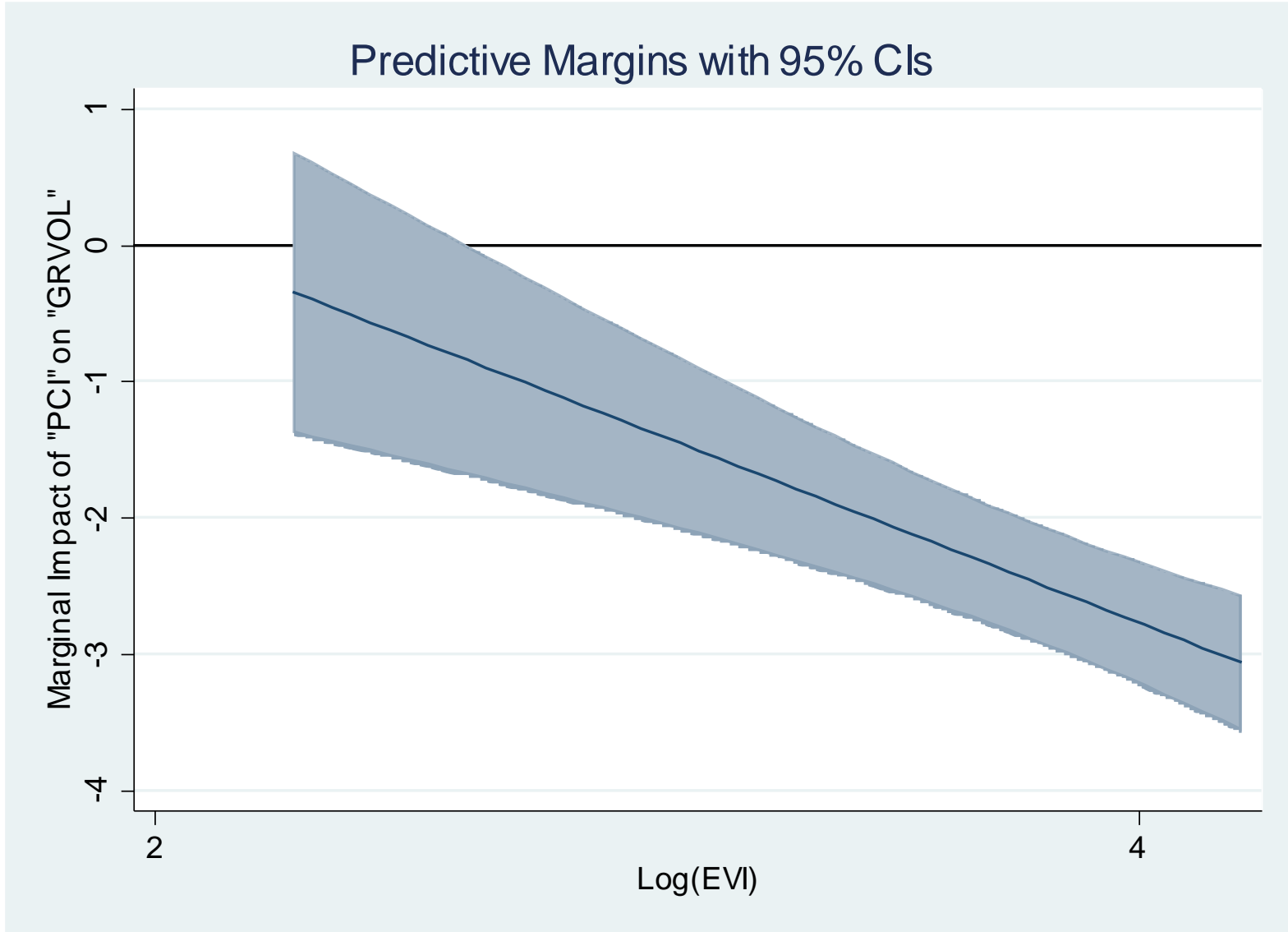

Source: Author 